Florida International University FIU Digital Commons

$10-20-2010$

\title{
An American Political Economy: Industry, Trade, and Finance in the Antebellum Mind
}

Christopher W. Calvo

Florida International University, ccalvo1978@yahoo.com

DOI: $10.25148 /$ etd.FI12041904

Follow this and additional works at: https://digitalcommons.fiu.edu/etd

\section{Recommended Citation}

Calvo, Christopher W., "An American Political Economy: Industry, Trade, and Finance in the Antebellum Mind" (2010). FIU

Electronic Theses and Dissertations. 568.

https://digitalcommons.fiu.edu/etd/568

This work is brought to you for free and open access by the University Graduate School at FIU Digital Commons. It has been accepted for inclusion in FIU Electronic Theses and Dissertations by an authorized administrator of FIU Digital Commons. For more information, please contact dcc@fiu.edu. 
FLORIDA INTERNATIONAL UNIVERSITY

Miami, Florida

AN AMERICAN POLITICAL ECONOMY:

INDUSTRY, TRADE, AND FINANCE IN THE ANTEBELLUM MIND

A dissertation submitted in partial fulfillment of

the requirements for the degree of

DOCTOR OF PHILOSOPHY

in

HISTORY

by

Christopher William Calvo 


\section{To: Dean Kenneth G. Furton}

College of Arts and Sciences

This dissertation, written by Christopher William Calvo, and entitled An American Political Economy: Industry, Trade, and Finance in the Antebellum Mind, having been approved in respect to style and intellectual content, is referred to you for judgment.

We have read this dissertation and recommend that it be approved.

Darden Pyron

Nicol Rae

Howard Rock

Peter Onuf

Kenneth Lipartito, Major Professor

Date of Defense: October 20, 2010

The dissertation of Christopher William Calvo is approved.

Dean Kenneth G. Furton College of Arts and Sciences

Dean Lakshmi N. Reddi University Graduate School

Florida International University, 2012 
(C) Copyright 2012 by Christopher William Calvo

All rights reserved. 


\section{DEDICATION}

Pastora Lozano Calvo 


\section{ACKNOWLEDGMENTS}

Several colleagues and family members have contributed to the completion of this dissertation. This project began years ago as an essay submitted in Dr. Pyron's American Civil War graduate seminar. His enthusiasm for the project provided me with the assurance to take this topic on. I consider Dr. Pyron a mentor and a close friend whose influence on my progress as a historian is treasured. Dr. Pyron taught me that writing history is more a discipline than an art. During the early stages of the research, Dr. Rock impressed upon me the value of extensive research and I appreciate greatly his services on the committee. I am also grateful to Dr. Rae for the afternoons spent discussing the literature on Jacksonian politics. Those moments shaped my understanding of the period more than he realizes. And it is with great honor that Dr. Onuf has taken the time to serve on the committee. I recognize him as a leader in the field and I feel privileged to have accessed his expertise. The staff in the History Department at Florida International University should be recognized for their constant professionalism, their generosity, and their kindness. Hayat Kassab-Gresham, Emily Carreras, Maria Ferrer Young, and Diana Cox (retired) deserve special commendations for the assistance they give students. I also wish to express gratitude for the Interlibrary Loan Staff at Florida International University.

I am especially indebted to Dr. Lipartito. As director of the committee he afforded constant encouragement, guided me throughout the course of this project, and offered invaluable personal and professional counsel. Dr. Lipartito has been the single most important factor in my professional development. He has kindly sacrificed his time and energy to ensure the completion of this dissertation and his confidence in my work has left me forever obliged. This expression of thanks is standard, but my appreciation is not.

I wish to thank my parents, Enrique and Suzzan Calvo, whose support has provided me the liberty to pursue advanced studies. Never did they question the schedule of my graduate career, nor the outcome. My greatest debt is to my wife. She has stood by me throughout this 
extended and grueling enterprise. Late nights, weekends, a silent house, inaudible mumblings, and the insufferable discussions on antebellum political economy she has endured with patient grace. This dissertation is yours as much as it is mine. Darcy, I cherish you dearly. 


\section{ABSTRACT OF THE DISSERTATION \\ ANTEBELLUM MIND \\ by \\ Christopher William Calvo \\ Florida International University, 2012 \\ Miami, Florida \\ Professor Kenneth Lipartito, Major Professor}

AN AMERICAN POLITICAL ECONOMY: INDUSTRY, TRADE, AND FINANCE IN THE

The purpose of this study is to assess American economic thought during the antebellum period. Antebellum political economy has been largely neglected by historians. They have ignored both the valuable contributions made by America's first political economists to domestic intellectual culture, as well as the importance of American economic thought in the transatlantic discourse. A dynamic, sophisticated, and complex political economy marks the antebellum era, and when studied in its proper context provides insight into how Americans understood the transformative economic changes they experienced.

This dissertation draws on an extensive body of primary and secondary literature. Special consideration is given to the more learned articulations of economic thought. However, recognizing the immature state of the science during the period under investigation works of various levels of theoretical erudition are referenced. In their attempts to fashion a distinctly American political economy domestic thinkers entertained a wide range of economic principles. Contrary to conventional wisdom the Americans were not absolutist in their dedication to British orthodoxy. Antebellum political economy manipulated British authorities to suit the immediate concerns of contemporaries, thus spoiling the essence of classical doctrine. This dissertation makes clear that few Americans accepted classical orthodoxy without important qualifications. 
Classical theory was confronted with its most systematic challenge by protectionists. Despite protectionism having shaped the course of American economic development, its theoretical underpinnings have been summarily discounted by historians and economists. Protectionists, however, afforded the quintessential expression of American antebellum political economy. This dissertation intends to rescue the protectionists from historical abandon and reclaim the position of relevance they enjoyed during their own time. The antebellum period also hosted a fiery set of intellectuals determined to upset the emerging free-market order, exhibiting a particular disdain for institutions of finance and the industrial ethos. Conservatives from the North and South aimed to slow America's march into the modern economy. These elements did not operate on the fringes of intellectual society, rather they represent something central to the American discourse and are illustrative of the difficulty attendant to classifying antebellum thinkers according to traditional notions of economic ideology. 


\section{TABLE OF CONTENTS}

CHAPTER

PAGE

I. Introduction: History and Antebellum Economic Thought...........................................

II. Laissez-faire and Moral Philosophy in the Northeast..................................................12

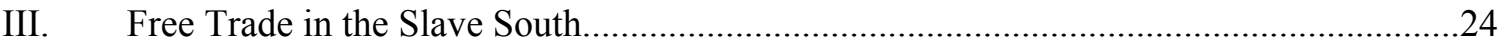

IV. Progress and Poverty: Malthus and Ricardo in America................................................40

V. The Crisis of Free Society: The Southern and Northern Reactionaries............................63

VI. Protectionism: An American Political Economy..........................................................

VII. Henry Carey, Nature, and the Destiny of Man...........................................................123

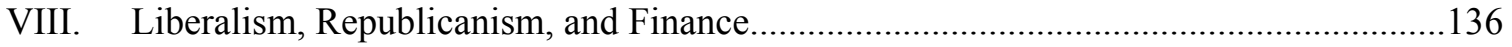

IX. Conclusion: The Old and the New in American Economics........................................167

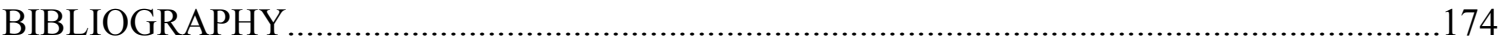

VITA 


\section{Chapter I}

Introduction: History and Antebellum Economic Thought

American economic thought before the Civil War has attracted very little scholarly attention.

Charles Dunbar set the trend in a widely read 1876 essay by arguing that antebellum American political economists had contributed "nothing towards developing the theory of political economy." Economic discourse in America, he wrote, suffered from a "general sterility." Eighty years later Joseph Schumpeter reiterated Dunbar's blanket dismissal in his History of Economic Analysis. Dunbar's appraisal, Schumpeter wrote, had "not been invalidated by the information made available by more recent research." The Austrian-import found in the pool of American economists of the pre-Civil War period, "no first-rate man among them, and they made nothing of the great opportunity before them."2 The dismissive tones of Dunbar and Schumpeter gave subsequent generations of historians little incentive to examine antebellum economic thought. $^{3}$

This dissertation intends to liberate antebellum political economy from the shadows of Dunbar and Schumpeter and reclaim for posterity the relevance antebellum thinkers enjoyed during their own time. American political economists wielded strong influence in the domestic discourse. They constructed a dynamic body of thought that shaped American perceptions of the national economic experience and they contributed in significant ways to the formation of economic policy. They also made important revisions to nineteenth-century economic formulas, particularly British classicism. Antebellum debates over industry, trade and finance drove an

\footnotetext{
${ }^{1}$ Charles Dunbar, "Economic Science in America, 1776-1876," The North American Review (January, 1876), pp. 140, 146.

2 Joseph Schumpeter, History of Economic Analysis (Oxford, 1954), pp. 514, 519.

${ }^{3}$ The criticisms of Dunbar and Schumpeter in part reflect the notion that economists who wrote outside of the classical and neoclassical traditions did not contribute to the scientific development of the economics discipline.
} 
intellectual wedge between American thinkers. Still, refuting classical orthodoxy was the decisive element that united antebellum political economy.

The historiography on antebellum economic thought, however, tends to minimize the differences by painting a broad intellectual consensus. For decades, the literature has been guided by Joseph Dorfman'sThe Economic Mind of American Civilization, 1606-1865 (1949).

Dorfman's work makes for an excellent reference, but his analysis is limited to a short Preface that asserts the consensus narrative of American intellectual history. "The most potent determinant of economic action and thought was world commerce," Dorfman argued, "the commerce that gave us treasure, the commerce that brought foreign goods and took our exports, that profited shipper, middleman, and speculator; the commerce, in short, that created the rich urban community and enlarged the money economy." Dorfman conceded other forces at play, but by the end of the period these had "shifted gradually toward liberalism, democracy, and agrarianism." ${ }^{, 5}$ The existence of the latter should not be understood as disrupting the commerceoriented laissez-faire consensus, Dorfman noted. "Again and again the farmers as well as the relatively unimportant laboring class," Dorfman wrote, "appeared in the arena as the auxiliaries of rival business factions for which they provided the bucolic pen names signed to 'capitalistic' pamphlets.",6

Dorfman's consensus interpretation implied that antebellum thought was marked by a near universal acceptance of the laissez-faire model. This interpretation was made more explicit in his analyses of individual political economists. Dorfman isolates antebellum thinkers who

\footnotetext{
${ }^{4}$ Joseph Dorfman, The Economic Mind of American Civilization, 1606-1865,vols.I and II (New York, 1946). Book 2, "From Independence to Jackson" and Book 3 "From Jackson to the Civil War" cover the periods dealt with here. Dorfman also published The Economic Mind in American Civilization, 1865-1918, vol. III (New York, 1949) and The Economic Mind in American Civilization, 1918-1933, vols. IV and V (New York, 1959).

${ }^{5}$ Dorfman, The Economic Mind of American Civilization, vol. I, p. ix.

${ }^{6}$ Ibid.,vol. I, pp. x-xi.
} 
wrote outside the laissez-faire tradition. He also underestimates the subtle, though important variations within the antebellum free-trade movement, and thus ignores the broader shift away from classical orthodoxy.

After Dorfman, a full generation passed before any scholar treated in a substantial way antebellum thought. ${ }^{7}$ In 1980, Paul Conkin'sProphets of Prosperity modified parts of Dorfman's sweeping consensus view. "Except for a common commitment to economic growth and to a proprietary society," Conkin argued, "our first economists scarcely agreed on any beliefs or values." ${ }^{\prime 8}$ Still, while Conkin identified areas of debate in antebellum thought, the general tone of his work amounted to a liberal-consensus reading of American intellectual history. Like Dorfman, Conkin stressed the affinity antebellum thinkers had for British laissez-faire. Indeed, America lacked a strong intellectual tradition of political economy precisely because domestic thinkers marched lock-step with British authorities. The Wealth of Nations, Conkin wrote, "quickly established itself in America as a work of tremendous authority." The French free-

\footnotetext{
${ }^{7}$ Paul Conkin, Prophets of Prosperity: America's First Political Economists (Bloomington, IN, 1980). Besides Dorman and Conkin, there have been other works in the historiography that inform my dissertation. These are, however, mostly outdated. Michael O'Connor, Origins of Academic Economics in the United States (1944; reprint New York, 1974); J.F. Normano, The Spirit of American Economics: A Study of the History of Economic Ideas in the United States Prior to the Great Depression (New York, 1943); Ernest Teilhac, Pioneers of American Economic Thoughtin the Nineteenth Century (New York, 1936); Frank A. Fetter, "The Early History of Political Economy in the United States," Proceedings of the American Philosophical Society (July, 1943); William Barber, ed., Economics and Higher Learning in the Nineteenth Century (New Brunswick, 1993); UgoRabbeno, American Commercial Policy (London, 1895); Edward Stanwood, American Tariff Controversies in the Nineteenth Century (1903; reprint, New York, 1974), vols. I and II; Malcolm Rutherford, ed., The Economic Mind in America: Essays in the History of American Economics (London, 1998); Michael Hudson, Economics and Technology in 19th-Century American Thought (New York, 1975); Judith Goldstein, Ideas, Interests, and American Trade Policy (Ithaca, NY, 1993); James Huston, Securing the Fruits of Labor: American Concepts of Wealth Distribution (Baton Rouge, LA, 1998); Allen Kaufmann, Capitalism, Slavery, and Republican Values: Antebellum Political Economists, 1819-1848 (Austin, TX, 1982). Besides Conkin, Hudson, Huston and Kaufman are the most recent works that offer a fairly sweeping and critical account on antebellum thought. Hudson and Huston are more topic specific. Kaufman's work is driven by a Marxist understanding of economic ideology. He is perhaps the most insightful historian on American economic thought, but his work is limited to mainly Daniel Raymond, Thomas Roderick Dew and Jacob Cardozo.

${ }^{8}$ Conkin, Prophets of Prosperity, p. 312.
} 
trader Jean Baptiste Say, Conkin argued, "had an enormous impact." And Ricardo, according to Conkin, "had the greatest impact on Americans."

This dissertation will show that antebellum political economists articulated serious reservations, both theoretical and ideological, about the laissez-faire paradigm. As much as America's domestic economy grew in accordance with the principles of Adam Smith, the nation's economic thought, as it was expressed by the period's most seasoned academic and public intellectuals did not subscribe to an absolutist laissez-faire ideology. Antebellum political economists made significant departures from the free-trade model. And they did so with complete knowledge of the authority British laissez-faire had in nineteenth-century economic discourse. Most antebellum thinkers did not try to "domesticate" British classicism; nor were they, as Conkin argued, powerless "to create their own universe of discourse."10

American economic thinkers built off the laissez-faire tradition to craft arguments that comported with the unique economic conditions of their new world. For some, this meant accepting parts of the laissez-faire model, but with distinctive American twists. Chapters 2 and 3 of this dissertation show that even within the antebellum free-trade movement, there lacked definitive consensus. American thinkers developed different types of laissez-faire political economy, each suited to the particular regional interests of the authors. This was especially the case in the South. Southerners manipulated laissez-faire logic to match Southern traditions. By the 1830s Southerners realized laissez-faire complimented the ideal of the negative state. They employed free-trade political economy to strike at the North by attacking protective tariffs and

\footnotetext{
${ }^{9}$ Ibid., pp. 17, 28, 30. Dorfman and Conkin consensus interpretation of American political economy compliments broader studies of antebellum society that depict a pervasive liberal-democratic-capitalist order. Louis Hartz, The Liberal Tradition in America: An Interpretation of American Political Thought since the Revolution (New York, 1955), is the authority on this interpretation. Richard Hofstadter, another consensus historian, argued American history is marked by the "common, bourgeois, entrepreneurial assumptions of most of the effective forces in American political life and the tendency of these forces to group ideologically around a Whiggish center rather than to be polarized in sharp ideological struggles." The American Political Tradition and the Men Who Made It (New York, 1948), pp. xxvii-xxxi.

${ }^{10}$ Conkin, Prophets of Prosperity, p. 17.
} 
combating assertions that the state could claim or destroy private property-notably slavery. Smith had denounced slavery, but the ostensible incompatibility between a Southern political economy of slavery and the enlightened, free-trade moral philosophy of Smith did not stop Southerners from becoming antebellum America's chief disseminators of laissez-faire. Nor did Southerners, hostile to industrialization, see their brand of laissez-faire inconsistent with British classicism and its emphasis on industry. Free traders in the South shaped laissez-faire into an intellectual strategy to advance the political doctrine of states-rights, defend an agrarian-based slave regime, and stall the emergence of a national industrial economy. It was, in short, not the economic liberalism of the British tradition.

In Northeastern colleges and universities professors taught a brand of laissez-faire doctrine quite different from the political economy of Southern free trade. In consequence, laissez-faire in the American discourse was split along regional lines and never united into a single intellectual movement. The influence of regional institutional and cultural conventions brought Northeastern free traders closer to the Smithian tradition. The Northeastern free traders emphasized the moral and religious benefits of market economies. They considered free-trade political economy as confirmation of a benevolent, Christian deity. Northeastern professors were typically clergy who might have otherwise distanced themselves from a discipline still linked to the materialism of David Hume. But because free trade in the Smithian tradition was originally a branch of moral philosophy, teaching political economy was amenable to the clerical style and substance of curricula in the Northeast. The sluggish pace with which Northeastern freetraders removed elements of moral philosophy and religion distinguished their interpretation of laissezfaire from the more secular versions of Southern free trade, and it was in stark contrast to the political economy of nineteenth-century British classicism. Moreover, the Northeastern clergy free traders largely rejected, on theological grounds, the pessimism of the classical school. Both the Southerners and the Northeastern cleric economists drew from British authorities, but the 
Americans followed an economic logic that was different from laissez-faire as it existed in the nineteenth-century British discourse.

The divisions between antebellum free traders and British laissez-faire are made more explicit in the American treatment of Thomas Malthus and David Ricardo. This is the subject of chapter 4 . This chapter demonstrates how antebellum thinkers largely abandoned Malthus and Ricardo, or manipulated their logic to suit distinctly American conditions. Antebellum economic and social conditions convinced domestic writers from both the North and South that the theories of Malthus and Ricardo were simply inapplicable. The few Americans who accepted Malthus and Ricardo, typically distorted these British authorities to advance their own special political and social prerogatives. It is not uncommon to find an American writer stressing certain conclusions of the British economists while flatly denying the legitimacy of others. In this way antebellum American writers created their own economic discourse out of the raw material of British classicism. By the 1850 s this tendency of American thinkers to twist the British classical tradition in ways that fit particular political and social agendas had reached its height. This was especially the case in the South, where the gloomy forecasts of the British pessimists were employed in a defense of slavery.

The American break from British classicism was largely a response to wide-spread assumptions about American exceptionalism. Declarations of American exceptionalism hark back to the colonial period, but during the antebellum era the concept became a central feature of American intellectual culture. ${ }^{11}$ The belief in American exceptionalism contributed to an almost constant invitation for antebellum writers to construct a native political economy. An American economic renaissance of sorts was heralded, one demanding an economic thought suited to the historically unique domestic conditions. It was determined that to best appreciate the nature of

\footnotetext{
${ }^{11}$ Dorothy Ross, The Origins of American Social Science (Cambridge, 1991); Arthur Ekirch, The Idea of Progress in America, 1815-1860 (New York, 1951); Carl Russell Fish, The Rise of the Common Man, 1830-1850 (New York, 1927).
} 
the American economy there required an alternative, nuanced political economy penned by domestic hands.

The task of creating a system of economic thought designed specifically for the American experience fell to the protectionists. Chapter 6 traces the intellectual evolution of antebellum protectionism. Protectionism was the most important development in antebellum economic thought and it has rightly been designated the American school of political economy. By fusing together various strains of domestic intellectual, social, economic and cultural history, protectionists captured the essence of the antebellum economic mind. These writers cherished a bouyant optimism, a strong commitment to national economic development, and a spirit of independence from the Old World. The protectionists substituted the pessimism of the classical tradition with a distinctly American understanding of economic phenomena based on an economics of affluence.

The popularity of protectionist thought and the practical application of protectionist policy throughout the nineteenth century illustrates the disconnect between American political economy and British classicism. For protectionists the exceptional conditions of America made permanent economic progress possible. By commanding through the will of human agency and the instruments of state what for the British thinkers was an uncompromising and arbitrary natural order, the protectionists aimed at catapulting the American economy into an unprecedented economic condition. Attaining economic and political independence was made possible by controlling what Smith had referred to as the "natural system of liberty." In these ways, protectionists challenged the foundational principles of laissez-faire. But protectionists did not believe their economic system was at odds with liberal values. Rather they thought that by regulating markets through tariffs they would increase the personal autonomy of American citizens and augment national sovereignty. As much as protectionists held in disdain the freetrade ideology, their economic theory managed a defense of an otherwise liberal, competitive, 
capitalist industrial order. Protectionists believed the tariff was capable of creating an industrial society with capitalists, machines and workers coexisting harmoniously. The industrial ideal that protectionists worked toward would avoid the dismal outcomes predicted by Malthus and Ricardo. In antebellum political economy it was the protectionists, not the free-traders, who promoted economic modernization and the expansion of industrial capitalism. Chapter 7 investigates the works of Henry Carey, the period's most important protectionist thinker. Carey united protectionism into a coherent economic ideology that remains the most significant contribution to the antebellum economic discourse.

Protectionists offered the most popular and influential antebellum rebuke of laissez-faire. A far more violent and darker rejection came from a small legion of Southern reactionaries and Northern laborites. Chapter 5 examines the economic thought of Southern reactionaries and Northern laborites responsible for the period's sharpest critique of bourgeois economic ideology. They include Southern agitators like George Fitzhugh and George Frederick Holmes, and labor activists like Langton Byllesby and Thomas Skidmore. Although the Southern reactionaries and Northern labor advocates often operated on the periphery of the domestic economic discourse, their ideas further showcase the lack of consensus in American thought.

The Southern and Northern radicals also reinforce the argument that antebellum political economy was not dedicated to the laissez-faire/classical model. They were perhaps the most intriguing sets of intellectuals in the antebellum catalogue of economic commentators, for they provoked a fundamental reclassification of ideological alignments by questioning traditional American values of natural liberty, property rights, personal economic sovereignty and state prerogative.

This chapter also invites substantial revisions to conventional notions of economic ideology as they existed within the framework of the antebellum discourse. By combining these groups into a single chapter, the intellectual relationship between these seemingly adverse 
economic ideologies are revealed as actually having shared a close affinity. Both groups desired a complete alteration of the existing economic order. And both groups couched their programs on a systematic critique of the laissez-faire industrial order. The interpretations of industrial society provided by the Southern reactionaries and Northern laborites were as dismal as the British classicists. The Southerners argued that the free market pushed much of humanity into a miserable condition, marked by exploitation, ceaseless drudgery, and a bare subsistence. Their opposition to industrial capitalism was based on a Tory-like morality that reflected Southern paternal values, Southern social and economic institutions, and an attachment to plantation slavery. The Northern laborites echoed the criticisms of the Southern reactionaries, but their analyses rested on a nascent socialist political economy then gaining favor in American industrial quarters. They demanded a redistribution of property, an end to the perceived exploitative tendencies of industrial labor, the abolition of economic classes, and a radical reconfiguration of commercial exchange. These groups shared important values and their relationship is indicative of the rather awkward intellectual alliances that emerged in the antebellum economic discourse.

While the consequences of industry and trade were the most heatedly debated economic topics of the era, finance inspired the most severe form of panic. Chapter 8 deals with the antebellum reaction to financial capitalism. This chapter argues that Americans held a variety of positions in their perceptions of finance, but most coalesced around a strong opposition to the expansion of financial capitalism. By the Jacksonian era financial institutions were deeply rooted in the economy, and during this period both the forces sympathetic to and those determined to resist financial capitalism matured into full-fledged political, social, and intellectual movements. Historians have paid considerable attention to Americans' suspicions of finance. However, they tend to reduce antebellum attitudes into either neatly organized antagonistic camps, or simply paint with a broad stroke an image of consensus. 
My dissertation concentrates on a middle variant often ignored in the historiography-political economists who were otherwise committed to the free market, but clear in their opposition to financial institutions, fearful of the moral, social, political, and economic residuals of the expansion of banks, credit, debt, and stock-corporations. The conventional wisdom on the relationship between advocates of free markets and finance was rare in the antebellum literature. American commentators on finance operated within ideological parameters unique to the antebellum period. A separate but related vein in the opposition literature on finance attempted to fuse a liberal economic creed with classical republicanism. In the historiography on the revolutionary and early national periods republicanism has attracted significant attention. ${ }^{12}$ Still, historians have largely overlooked the subtle differences between republican critics of finance in the antebellum discourse. ${ }^{13}$ Nor have historians done justice to the opponents of finance by representing them as radical outliers. Antebellum critics of finance were essential components of the era's economic thought, reflecting an engagement with the virtues of the free market but with a cautionary element that recognized the dangers of unfettered finance.

America's response to the development of financial institutions illustrates the dialectic tensions attendant to the nation's economic ideology. The aim of my work is to contextualize the conflicts in which Americans constructed their economic thought. As evidence, my dissertation draws on an extensive body of antebellum economic literature, with special consideration given to the more academic, or abstract writings. However, recognizing the period's lack of professionalization in the field of economics, I also incorporate fair discussion of more popular

\footnotetext{
${ }^{12}$ Bernard Bailyn, The Ideological Origins of the American Revolution (Cambridge, MA, 1967); Gordon Wood, The Creation of the American Republic (New York, 1969); J.G.A. Pocock, The Machiavellian Moment: Florentine Political Thought and the Atlantic Republican Tradition (Princeton, 1975);Drew McCoy, The Elusive Republic: Political Economy in Jeffersonian America (Chapel Hill, 1980).

${ }^{13}$ The notable exceptions are Stuart Banner, Anglo-American Securities Regulation: Cultural and Political Roots, 1690-1860 (Cambridge, 1998); Sean Wilentz, Chants Democratic: New York City and the Rise of the American Working Class, 1788-1850 (New York, 1984);Major Wilson, "The 'Country' versus the 'Court': A Republican Consensus and Party Debate in the Bank War," Journal of the Early Republic (Winter, 1995).
} 
tracts. Economic knowledge was not monopolized by a single group. It was disseminated by academics, farmers, merchants, craftsmen, mechanics, industrialists, pamphleteers, journalists, and politicians, many of whom, despite obtaining nothing near to what the present age would consider sufficient training, were confident enough in their expertise to claim the title of "political economist.' In the current study the latter term is used liberally, conferred upon those who contributed to what stands as a large and diverse assemblage of economic knowledge, found in speeches, memorials, journals, newspapers and academic publications. Perhaps the most difficult task of intellectual history is patching together the ideas and passages of disparate groups into a representative whole. This is particularly the case with American economic thought, where sharp differences encumber the formulation of broad generalizations. Still, intellectual culture in antebellum America was encouraging and pursuant of an economic discourse, and when examined closely improves our appreciation of the psychology of America's homo economicus and broadens our understanding of the theoretical basis for America's empire of wealth. 


\section{Chapter II}

Laissez-faire and Moral Philosophy in the Northeast

Only three months before Thomas Jefferson began writing the Declaration of Independence,

Adam Smith published his Wealth of Nations. Antebellum Americans eager to find significance in the historical connection between Smith and the nation's founding celebrated the concurrence. ${ }^{1}$

"The nativity of the science is to be dated from that event, and the coincidence is to be remarked that it was contemporaneous with our Declaration of Independence in 1776."2 Today, conventional wisdom still links the two. "The ideas of Adam Smith," one historian has recently written, "helped form the model for the development of the American economy." Another has argued that "the United States has consistently come closer to the Smithian ideal over a longer period of time than any other nation." ${ }^{3}$ Many of Smith's recommendations were implemented as antebellum policy. In the antebellum economic discourse, however, few Americans were absolutist in their following of Smith.

This chapter explores laissez-faire political economy in the antebellum Northeast. In contradiction of the conventional wisdom, free-trade thinkers in the Northeast largely ignored the economic logic of Smithianlaissez-faire. Instead, Smithianlaissez-faire was championed for its moral consequences. Although Smith is remembered for his economic discussion, his political

\footnotetext{
${ }^{1}$ On the influence of Smith's Wealth of Nations in antebellum America see Paul Conkin, Prophets of Prosperity: America's First Political Economists (Bloomington, 1980), p. 17; Samuel Fleischacker, "Adam Smith's Reception Among the American Founders, 1776-1790," William and Mary Quarterly, vol. 59, no. 4, 2002; Joseph Dorfman, The Economic Mind in American Civilization, 1606-1865 (New York, 1946), vol. II, p. 512. On the existence of shared ideas between Britain and America generally see Robert Kelley, The Transatlantic Persuasion: The Liberal-Democratic Mind in the Age of Gladstone (New York, 1969); Michael Kraus, The North Atlantic Civilization (Princeton, 1957); Frank Thistlethwaite, The AngloAmerican Connection in the Early Nineteenth Century (New York, 1971).

2 "Political Economy," The Southern Review (February, 1832), p. 493

${ }^{3}$ Roy Smith, Adam Smith and the Origins of American Enterprise: How America's Industrial Success was Forged by the Timely Ideas of a Brilliant Scots Economist (New York, 2002), p. 201; John Steele Gordon, An Empire of Wealth: The Epic History of American Economic Power (New York, 2004), p. 67.
} 
economy was based on moral philosophy. ${ }^{4}$ The Northeastern version of laissez-faire followed in this strain of his thought. The clergy-academics of the Northeastern free-trade movement combined a strikingly cosmopolitan perspective of international trade and a general whiggish tone to highlight the potential laissez-faire policies had in creating a just and righteous society.

The preference for moral philosophy in Northeastern laissez-faire followed logically from the socially-conservative institutional and cultural factors distinct to the region. ${ }^{5}$ Academic instruction of political economy in the Northeast was taught to college seniors in what was considered the climax of an early nineteenth-century higher education, a course in moral philosophy. The subject, according to one historian, "studied human affairs as the realm within which individuals sought moral improvement." As it was treated in America's most prestigious colleges, free-trade doctrine provided a strategy for enhancing material wealth, but it was more concerned with designing a society founded on sound moral principles.

Smithian economic philosophy blended well with the devout and dutiful nature of Northeastern curricula. The Scotsman's emphasis on the universality of free-trade principles, the benign qualities of the natural economic order, and the cosmopolitan character of free trade that encouraged mutually advantageous exchange complimented the religious character of Northeastern academia. Almost all of the region's institutions of higher learning maintained

\footnotetext{
${ }^{4}$ A sample of the historiography on Smith includes Joseph Cropsey, Polity and Economy: With Further Thoughts on the Principles of Adam Smith (South Bend, IN, 2001); Andrew Skinner, A System of Social Science: Papers Relating to Adam Smith (Oxford, 1996); T.D. Campbell, Adam Smith's Science of Morals (London, 1971); Vivienne Brown, Adam Smith's Discourse: Canonicity, Commerce, and Conscience (New York, 1994); Gloria Vivenza, Adam Smith and the Classics: The Classical Heritage in Adam Smith's Thought (Oxford, 2001); Charles Griswold, Adam Smith and the Virtues of Enlightenment (Cambridge, 1999); Glen Morrow, The Ethical and Economic Theories of Adam Smith (New York, 1969); Jacob Viner, The Long View and the Short (Glencoe, IL, 1958); Donald Winch, Adam Smith's Politics: An Essay in Historiographic Revision (Cambridge, 1978); J. Ralph Lingred, The Social Philosophy of Adam Smith (The Hague, 1973).

${ }^{5}$ The Northeastern brand of free trade also corresponded to the cultural and commercial interests of the region. Both the Northeastern and Southern varieties of free-trade were wedded to institutions that by the end of the nineteenth-century had lost influence in American society. Scientific analysis trumped divine explanation in academia, especially in political economy, and Southern slavery died at Appomattox.

${ }^{6}$ Dorothy Ross, The Origins of American Social Science (Cambridge, 1991), p. 36.
} 
close ties with the Church and clergy professors did most of the instruction. Congregationalists had their Harvard and Yale, the Episcopalians, Penn and Columbia, the Presbyterians, Princeton, and the Baptists, Brown. Curricula emphasized theology, moral philosophy, biblical studies, and occasional direction in mathematics and the physical sciences. ${ }^{7}$

Professors in the Northeast were almost always clerics and their letter of instruction almost always conservative. The relationship between Church and antebellum academic institutions worked against the introduction of new curriculum, especially a discipline whose pioneers were the skeptic David Hume and the deist Smith. American colleges were founded and funded under the assumption that students were taught civil and religious obedience that aimed at the maintenance of social tranquility. During the antebellum period colleges continued in this tradition by operating essentially as aristocratic theocracies. ${ }^{8}$

When political economy was introduced as an autonomous discipline, it entered stripped of its radical, materialist associations. ${ }^{9}$ Laissez-faire among the antebellum Northeastern clergyacademics was, in the words of one historian, "a sedative, not a stimulant;" it was employed to advance "defensive social campaigns." 10 Students were encouraged to answer the merchant's calling, rather than the radical agitator's. Pacifying or discrediting the latter became important as

\footnotetext{
${ }^{7}$ Joseph Dorfman, The Economic Mind in American Civilization, 1606-1865 (New York, 1946), vol. I, p. 112; Merle Curti, The Growth of American Thought (New York, 1951), p. 224; Michael Hudson, Economics and Technology in 19 ${ }^{\text {th }}$-Century American Thought (New York, 1975), pp. 22-33.

${ }^{8}$ William Barber, ed., Economists and Higher Learning in the Nineteenth Century, pp. 4-5; Dorfman, The Economic Mind in American Civilization, vol. I, p. 112; Dorfman, The Economic Mind in American Civilization, 1606-1866, vol. II, p. 512; Curti, The Growth of American Thought, p. 224. On the wider influence of Christianity in American liberal political culture see James T. Kopplenberg, "The Virtues of Liberalism: Christianity, Republicanism, and Ethics in Early American Political Discourse," The Journal of American History (June, 1987).

${ }^{9}$ Michael O’Connor, Origins of Academic Economics in the United States (New York, 1974),pp. 78-94.

${ }^{10}$ Ibid, pp. 106, 108. Following the French Revolution, egalitarian and democratic interpretations of Smith were increasingly minimized in the discourse. Dugald Steward, professor at Edinburgh University, 1775 1820 , is often credited with having purged Smithian political economy of its potential for 'Jacobinism.' Richard Teichgraeber, "Adam Smith and Tradition: Wealth of Nations before Malthus," Stefan Collini, Richard Whatmore and Brian Young, eds., Economy, Polity, and Society: British Intellectual History, 1750-1950 (Cambridge, 2000), pp. 95-97.
} 
the Northeast developed industrially. Far from being in the vanguard of intellectual movements, early American colleges aimed to preserve the established social order. ${ }^{11}$ The accumulation of wealth was reward for moral, industrious behavior; while poverty a mark of an individual's deficiency.

The religious and moral impulse of Northeastern laissez-faire differed significantly from most others in the trans-Atlantic free-trade movement. Freeing political economy from theology and moral philosophy took almost a century longer in America than it did in Britain. ${ }^{12}$ Incorporating sacred principles into free trade helped popularize the ideology with American intellectual circles otherwise closed to the nuances of Enlightenment thought. By tying elements of Christianity to free-trade political economy, the Northeast clergy-academic helped legitimize the discipline in American institutions of higher learning. If laissez-faire political economy was censored by some critics for its materialism, presenting free-trade doctrine as evidence of a higher power facilitated its acceptance as a branch of learning worthy of instruction in America's religiously oriented colleges. Just so, Northeastern intellectual culture required political economy to assimilate religious conventions before the science was permitted to secede as an independent field of study. Deliverance of American political economy from its theological heritage was no easy task, it was one of several paradigmatic challenges the discipline faced during its formative years and it had a profound impact on the evolution of domestic economic thought.

This is not to say American free traders were disengaged from an increasingly secular economic discourse. Even after the ascendancy of Ricardo, a British evangelical strain of free

${ }^{11}$ O'Connor, Origins of Academic Economics in the United States, pp. 80-89.

12 Jacob Viner, "Fashion in Economic Thought," Douglass Irwin, ed., Essays on the Intellectual History of Economics (Princeton, 1971), p. 190; A.W. Bob Coats, On the History of Economy Thought (London, 1992), p. 343. William Lewtin, The Origins of Scientific Economics: English Economic Thought, 16601776 (London, 1963), pp. 81, 147-148; Margaret Schabas, The Natural Origins of Economics (Chicago, 2005), pp. 2, 12; Joyce Appleby, Economic Though and Ideology in $17^{\text {th }}$-Century England (Princeton, 1978), p. 54. Lewtin argues that as early as the mid-seventeenth century the Church in England had lost its authority to speak on economic matters. 
trade emerged, touting the moral and spiritual benefits of open markets. ${ }^{13}$ The coexistence of an American and British free-trade movement that accentuated the spiritual over the material illustrates the intellectual ties between the two nations. It also indicates that the Northeastern clergy-academics influenced the paradigmatic evolution of the nascent science. Contrary to claims that antebellum Americans made negligible contributions to political economy, the Northeastern clergy-academics had an impact on the development of free-trade ideology. ${ }^{14}$ The political economy of a variety of men illustrates these common ties and developments.

Columbia professor John McVickar exemplified the connection between Christian piety, moral philosophy and free-trade political economy in antebellum America. Born in 1787 into an elite New York City merchant family, he entered Columbia at thirteen as a student and graduated four years later at the top of his class. Ordained by the Episcopal Church in 1812, McVickar's 47 years at Columbia were preceded by serving as rector of the Church of St. James, Hyde Park, New York. In 1817 he returned to his alma matter as professor of moral philosophy. ${ }^{15}$

Throughout his career McVickar worked to popularize free-trade doctrine in America. He was largely responsible for the American introduction to Ricardo through his 1825 Outlines of Political Economy, which republished with extensive editor's notes J.R. McCulloch's essay "Political Economy." ${ }^{16}$ McVickar considered inquiry into laissez-faire principles an opportunity to reunite American and British minds. "It may serve to moderate the hasty zeal...by showing how nearly reflecting men on both sides of the Atlantic arrive at the same conclusions, and thus tend to

\footnotetext{
${ }^{13}$ Boyd Hilton, The Age of Atonement: The Influence of Evangelicalism on Social and Economic Thought, 1785-1865 (New York, 1988).

${ }^{14}$ Charles Dunbar, "Economic Science in America, 1776-1876," The North American Review (January, 1876), pp. 140, 146; Joseph Schumpeter, History of Economic Analysis (Oxford, 1954),pp. 514,519

15 J.B. Langstaff, The Enterprising Life: John McVickar, 1787-1868 (New York, 1961), p. 74.

${ }^{16}$ McCulloch's essay appeared in the Encyclopedia Britannica in 1824 and helped establish Ricardian principles as classical orthodoxy.
} 
draw together two kindred nation, whom an unwise and illiberal policy has too often disunited."17 But free trade did more than strengthen the bond between America and Britain. For McVickar laissez-faire was the harbinger of universal fraternity. Free trade aided humanity in its historical quest to eliminate those evil tendencies that exist between men. "It inclines them to drop the sword from their hands, by demonstrating to them, that they are about to plunge it into their own bowels." Free trade also moderated national hostilities. "It teaches among nations and federative states," McVickar wrote, "the all-important lessons of peace and mutual benefits...It unites nations, not by treatise or federations...but by the laws of mutual interest." ${ }^{" 18}$ What scripture revealed to be man's duty, political economy exposed to be in their interest.McVickar believed it his primary function to bridge the principles of all sciences and divine scripture, for every piece of human knowledge was evidence of Providence's design.

McVickar's interest in political economy was also driven by a desire to employ the science as a vehicle to spread his theology. Although McCulloch, the eminent Scottish economists, noted in 1824 that political economy was divorced from the study of ethics-"the production of wealth is the only question they admit," McVickar argued for the ethical and religious consequences for teaching the science. ${ }^{19}$ "Though it be but the science of wealth, yet does it show that wealth to be the result of the moral and intellectual, as well as the physical powers of man. It demonstrates that to man, ignorant and vicious, there is no road to wealth. ${ }^{20}$ The economist's mission was to uplift and enrich individuals. ${ }^{21}$ "Gold and virtue,"

\footnotetext{
${ }^{17}$ John McVickar, Introductory Lecture to a Course in Political Economy Delivered at Columbia University (London, 1830), p. i.

${ }^{18}$ Ibid., p. 9.

${ }^{19}$ John McVickar, Outlines of Political Economy: Being a Republication of an Article upon that subject contained in the Edinburgh Supplement to the Encyclopedia Britannica (1825; reprint, New York, 1966), p. 160.

${ }^{20} \mathrm{McVickar}$, Introductory Lecture to a Course in Political Economy, p. 5.
} 
McVickar wrote, are not "balanced against each other in opposite scales." Indeed, he continued, "the greatest pursuit of wealth is still the greatest safeguard of virtue." 22

At Brown, Francis Wayland gave further form to the link between Christianity and political economy. Wayland was born in 1796 in New York City. Like McVickar, Wayland served the church before entering the academy. The five years prior to Wayland accepting the posts of president and professor of moral philosophy at Brown were spent at the First Baptist Church of Boston. ${ }^{23}$ Upon arriving at Brown in 1827 Wayland introduced political economy in his lectures on moral philosophy and in the following year the subject was included in the university's catalogue. Wayland was also responsible for antebellum America's most popular economics textbook, The Elements of Political Economy. Published in 1837, it was standard reading for students. The work went through eighteen editions before the Civil War and sold nearly 60,000 copies. $^{24}$

Like McVickar, Wayland employed Smithian principles to strengthen the connections between laissez-faire and moral philosophy. "The principles of political economy are so closely analogous to those of Moral Philosophy, that almost every question in the one, may be argued on grounds belonging to the other." 25 He insisted the natural economic order established a direct correlation between virtuous behavior and the accumulation of wealth. "The circulation of the scriptures, the inculcation of moral and religious truth upon the mind of man, by means of the

\footnotetext{
${ }^{21}$ Joseph Dorfman, "The Reverend John McVickar, Christian Teacher and Economists," Joseph Dorfman and Rex G. Tugwell, Early American Policy: Six Columbia Contributors (Plainview, 1972), pp. 116, 132.

${ }^{22}$ McVickar, Introductory Lecture to a Course in Political Economy, pp. 6, 7.

${ }^{23}$ Joseph Blau, editor's introduction in Francis Wayland's The Elements of Moral Science (1837; reprint, Cambridge, MA, 1963),pp. xii-xv; O'Connor, Origins of Academic Economics in the United States, p. 77; Dorfman, The Economic Mind in American Civilization, vol. II, pp. 758-567.

${ }^{24}$ William Barber, "Political Economy from the Top Down: Brown University," William Barber, ed., Economists and Higher Learning in the Nineteenth Century (New Brunswick, 1993), p. 74.

${ }^{25}$ Francis Wayland, The Elements of Political Economy (New York, 1837), p. vi.
} 
Sabbath schools, and the preaching of the gospel, are of the very greatest importance to the productive energies of a country." ${ }^{26}$ 'In the sweat of thy brow shalt thou eat bread' was characteristic of Wayland's doctrinal disposition. "If a man complain because God made him to labor; it is a difficulty which the complainant must settle with his Maker." ${ }^{27}$ In his discussion of paupers and poor relief, Wayland concluded "the fault lies, not in their wages, but in themselves." And he continued logically, "of course, the correction must come, not from a change in wages, but from a change in habits." ${ }^{28}$ Connecting laissez-faire to a Protestant ethic, Wayland believed free-trade political economy compelled the masses to righteous and industrious behavior.

For Wayland, free trade was also proof of a providential order. Although separated by wide distances, people required each other for sustenance. Thus, Providence constructed a cosmopolitan trade regime that compelled humanity to cultivate a Christian fraternity. The laws that governed universal exchange were established by God, scientifically observable, and designed so "that men should live together in friendship and harmony." 29 The theory of comparative advantage was akin to divine revelation. "From this universal dependence, we learn that God intends nations, as well as individuals, to live in peace, and to conduct themselves towards each other upon the principles of benevolence. ${ }^{30}$ Free traders like Wayland held an enlightened world view of international relations, where nations worked peaceably toward reciprocal benefit. The Northeastern free-traders looked externally, beyond America's borders, to

\footnotetext{
${ }^{26}$ Ibid., pp. 138-139.

${ }^{27}$ Ibid., pp. 124-125.

${ }^{28}$ Ibid., p. 329.

${ }^{29}$ Ibid., p. 90.

${ }^{30}$ Ibid., p. 173.
} 
a benign global market coordinated to foster a humanitarian ethic and weaken those prejudices which disposed men to acts of war and national rivalry. ${ }^{31}$

Wayland's positive view of the economic order broke with the pessimism of nineteenthcentury British classicism. His spiritual commitments drew him closer to the more optimistic Smith. Humanity, Wayland argued, was not destined for the dreary existence predicted by Malthus and Ricardo. Although Wayland favored agriculture as "the most healthy employment...attended by the fewest moral temptations," he did not believe industrialization hastened labor's demise. ${ }^{32}$ The providential order intended for each successive generation to enjoy greater material prosperity. Improvement is the permanent condition. Through the more efficient application of labor, the discovery of new technologies, and augmented investments of capital, those who in earlier times might expect to suffer privations enjoyed comfort. "It is thus that a society, age after age, grows rich, and each successive race of men leaves the world more richly provided with means and facilities of production, than it found it., 33

An attachment to Christian ethics drove a wedge between Wayland and the British classicists in still other ways. In his seminal piece on moral philosophy Wayland reverted to an almost pre-modern form of economic thought when he offered a critique of self-interest. Selflove was sometimes least productive of social and individual happiness. The economic order was not calculated "to secure the happiness of any single individual," Wayland found, "and he who devises his plan with sole reference to himself must find them continually thwarted by that Omnipotent and Invisible Agency which is overruling all things.",34

\footnotetext{
${ }^{31}$ Nicholas Onuf and Peter Onuf, Nations, Markets, and War: Modern History and the American Civil War (Charlottesville, VA, 2006), pp. 176, 182.

${ }^{32}$ Wayland, The Elements of Political Economy, pp. 40, 100-104.

${ }^{33}$ Ibid., p. 30.

${ }^{34}$ Ibid., p. 60.
} 
Wayland and McVickar represented a religious vein in American economic thought that dates to the colonial period. Theological and ethical imperatives played a powerful role in early American political economy. ${ }^{35}$ The economic literature of the colonies emphasized the role of clerics in maintaining an orderly and hierarchical society to counter the increasingly commercialized nature of social relations. Northern colonists calculated a 'just price,' applied the golden rule of the Old Testament to economic exchange, and filled broadsides with anti-merchant rhetoric critical of the corruptive and anti-social tendencies of trade and money. Influential thinkers like John Winthrop of Massachusetts interpreted scripture to defend public over private economy, state surveillance and control over the distribution of wealth, and struck against the notion of buying cheap to sell dear. ${ }^{36}$ Winthrop also found interest sacrilege. Lend money to those least able to repay, and later forgive the insolvent debtor, or better, consider your loan an act of Christian charity. ${ }^{37}$ Pennsylvania Quakers also believed religious doctrine paramount when directing economic policy. Sumptuary laws were not uncommon, and some expected the Church to take the lead role in guarding against inflation. ${ }^{38}$

McVickar's discussion of criteria for restricting free trade illustrates the lasting influence Christian moralism had on Northeastern economic thought. "If...individual gains may be pursued to the detriment of national wealth," McVickar wrote, "then must the guardians of the national

${ }^{35}$ R.H. Tawney, Religion and the Rise of Capitalism (London, 2000), pp. 89-131.

${ }^{36}$ Henry William Spiegel, ed., The Rise of American Economic Thought (Philadelphia, 1960), p. 6.

${ }^{37}$ John Winthrop, A Model of Christian Charity (1630), Marianne Johnson, Seven G. Medema and Warren J. Samuels, eds., Foundation of the American Economy: The American Colonies From Inception to Independence. From Theocracy to Secular, Materialist Commercial Society (London, 2003), vol.I, pp. 3538,45 .

${ }^{38}$ William Penn, A Brief Account of the Province of Pennsylvania (1681) and A Further Account of the Province of Pennsylvania (1685), eds. Johnson, et. al., Foundation of the American Economy: The American Colonies From Inception to Independence, vol. I; Increase Mather, The Great Blessing of Primitive Counsellors (1693), eds., Johnson, et. al., Foundation of the American Economy: The American Colonies From Inception to Independence, vol. I; Stephen Innes, Creating the Commonwealth: The Economic Culture of Puritan New England (New York, 1995); E.A.J. Johnson, American Economic Thought in the Seventeenth Century (New York, 1961). 
welfare be ever upon the watch against individual encroachment." ${ }^{39}$ The conditions McVickar presented for limiting free enterprise included "those necessary preparations for a state of war." But McVickar struck a tone reminiscent of colonial times when he censured "home speculation," as well as those occasions when "individual profits are....extracted from the miseries of other, from the vices and passions of society."40

The transition from medieval scholasticism to secular rationalism was for American political economy a cumbersome trail. Wayland and McVickar gave sharp expression to the historical dialectic between Christianity and economic thought. They employed the moral/economic philosophy of Smith to facilitate acclimation of free-trade principles to prevailing social and cultural institutions in the Northeast. In doing so, the Northeastern freetraders signaled their opposition to the analytical transformations within the laissez-faire tradition. ${ }^{41}$ McVickar and Wayland did not hold fast to the methodological developments ushered in by the more secular Ricardo. Instead, they resorted to divine explanation and standards of moral propriety.

McVickar and Wayland conformed to the social prerogatives of clerical elements committed to employing laissez-faire toward the construction of a pious society. This was a consequence of the prolonged association between academic and Church institutions in the antebellum Northeast. It was also owing to Northeastern academics approaching political economy from the disposition of a moral philosopher. The inability of McVickar and Wayland to recognize that laissez-faire was splitting from its Smithian roots and moving closer to nineteenth-

\footnotetext{
${ }^{39}$ McVickar, Outline of Political Economy, p. 90.

${ }^{40}$ Ibid.,pp. 90-91. McVickar was also a strong supporter of public work projects like the Erie Canal. See Dorfman's introductory essay to Outlines of Political Economy, "On the Naturalization of Ricardian Economics in the United States," p. 6.

${ }^{41}$ T.W. Hutchison, On Revolutions and Progress in Economic Knowledge (Cambridge, 1978), pp. 54-57; Donald Winch, Riches and Poverty: An Intellectual History of Political Economy in Britain, 1750-1834 (Cambridge, 1996), pp. 19-22, 354-356.
} 
century technical modes of analysis illustrates the region's reticent intellectual culture. In this sense, free-trade political economy was not in the avant-garde of social and intellectual change.

The Northeastern political economists did not have a domestic monopoly on the instruction of the budding science. The South developed its own distinct form of free-trade. And like the Northeastern brand, the Southern version reflected the region's intellectual heritage, social customs, and institutional traditions. Institutions of higher learning in the South were decidedly secular. And while the South emphasized a practical, policy-oriented brand of free trade that illustrated the region's anti-intellectual culture, the Northeastern economists celebrated the merits of metaphysical erudition. Neither did the Northeastern economists exhibit a rigid, doctrinal commitment to anti-statism. Although the Northeastern free-traders celebrated individual enterprise and were generally suspicious of legislative initiatives, they did not employ laissez-faire as a vehicle to advance states-rights ideology.

As an intellectual movement, antebellum free-trade was divided by sectional lines. A disassociation existed between free-traders in the North and South. Despite advocating the same policy, neither side seemed interested in what the other was saying. The emphasis paid to moral philosophy by the clergy-economists was difficult to reconcile with the pro-slavery influence in Southern free trade. In consequence, the American free-trade movement was missing an element of cohesiveness. A division, both politically and intellectually, that likely inhibited the promulgation of free-trade policy during the antebellum era. ${ }^{42}$ The division also limited the dissemination of British classicism in the domestic discourse, leaving open a cerebral void in the American economic mind that was ultimately filled by the protectionists.

\footnotetext{
${ }^{42}$ On American trade policy, see Frank Taussig, The Tariff History of the United States (New York, 1964); Percy Ashley, Modern Tariff History: Germany-United States-France (New York, 1970); Jonathan Pincus, Pressure Groups and Politics in Antebellum Tariffs (New York, 1977).
} 


\section{Chapter III}

Free Trade in the Slave South

The laissez-faire movement in the South arose in a fundamentally different environment than the Northeast. The Southerners adapted free-trade ideology to reflect their own particular intellectual, cultural, and institutional traditions. In contrast to the religiously-inspired Northeastern political economists, laissez-faire thinkers in the South ignored Smithian moral philosophy. The Southerners pushed free-trade political economy toward secular analysis, discounting appeals to a higher power and deflecting concerns of ethical responsibility in favor of practical policies. ${ }^{1}$

Most critically, slavery was at the center of Southern free-trade political economy. Still, the region's attachment to laissez-faire complimented a broader Southern ideology. Free trade offered Southerners a device to preserve the region's political strength in national affairs. The latter was thought to have been secured by the South's economic relevance, which rested on the perpetuation of slavery. By the 1830s laissez-faire evolved into an economic appendage to states-rights political doctrine. Thomas Cooper and John Calhoun cemented the association during the nullification crisis. ${ }^{2}$ As the nation drew closer to the Civil War, the bond between states-rights and free trade became almost inseparable. Furthermore, laissez-faire was also adjusted to accommodate the anti-industrial bent of Southern economic culture. ${ }^{3}$ In this regard,

\footnotetext{
${ }^{1}$ Michael O'Brien, Conjectures of Order: Intellectual Life and the American South, 1810-1860 (Chapel Hill, NC, 2004), vol. II, p. 888.

${ }^{2}$ For the nullification crisis, see Sean Wilentz, The Rise of American Democracy (New York, 2005), pp. 374-379; Arthur Schlesinger, The Age of Jackson (Boston, 1946), pp. 34, 95-96; John Ashworth, Slavery, Capitalism, and Politics in the Antebellum Republic, Volume I: Commerce and Compromise, 1820-1860 (Cambridge, 1995), pp. 135-136, 202-203, 333-335; Harry Watson, Liberty and Power: The Politics of Jacksonian America (New York, 2006), pp. 117-119, 129-131; Merrill Peterson, Olive Branch and Sword: The Compromise of 1833 (Baton Rouge, LA, 1982).
} 
the Southern free-trade movement was radically different from all other free-trade movements in the trans-Atlantic discourse. ${ }^{4}$ The Southern version of laissez-faire drew heavily on an American agrarian tradition and sponsored a program of national economic development friendly to Southern agrarian institutions. ${ }^{5}$ In short, free-trade thought advanced the slave interest, but it corresponded well to other components of the Southern mind.

Thomas Cooper was the principal intellectual force behind the Southern free-trade movement. Born in 1759 in London, Cooper emigrated to the United States in 1794. He first won notoriety in America through a series of stinging attacks in 1799 on President John Adams. Cooper scoffed at the administration's Sedition Act, the same act under which he would be charged with libel. In 1800 he served a six month prison sentence for an article published in the Northumberland, Pennsylvania Gazette. ${ }^{6}$ Cooper went on to teach at Carlisle College (Dickinson) and later the University of Pennsylvania. He eventually settled in Columbia as professor of chemistry at South Carolina College. In 1821 he became the college's president, a position held

\footnotetext{
${ }^{3}$ Louis Hartz, The Liberal Tradition in America: An Interpretation of American Liberal Thought Since the Revolution (Chicago, 1968), pp. 166-182; Eugene Genovese, The Political Economy of Slavery: Studies in the Economy and Society of the Slave South (New York, 1965), pp. 24-34; Eugene Genovese, The Slaveholder's Dilemma: Freedom and Progress in Southern Conservative Thought, 1820-1860 (Columbia, SC, 1992), pp. 6, 35-37, 56-57; Wilfred Carsel, "The Slaveholders' Indictment of Northern Wage Slavery," The Journal of Southern History (November, 1940); William Dodd, "The Social Philosophy of the Old South," The American Journal of Sociology (May, 1918).

${ }^{4}$ Karl Polayni, The Great Transformation: The Political and Economic Origins of Our Times (Boston, 2001).

${ }^{5}$ Nicholas Onuf and Peter Onuf, Nations, Markets, and War: Modern History and the American Civil War (Charlottesville, VA, 2006), p. 328.

${ }^{6}$ Michael O'Connor, Origins of Academic Economics in the United States (New York, 1974), p. 48; O'Brien, Conjectures of Order, p. 896; John Roscoe Turner, The Ricardian Rent Theory in Early American Economics (New York, 1921),pp. 54-57; Joseph Dorfman, The Economic Mind in American Civilization, 1606-1865 (New York, 1946), vol. II, pp. 528, 534; Abram Flora, "Economic Thought in South Carolina, 1820-1860" (Ph.D. diss., University of North Carolina, 1957), pp. 2-3, 34, 35; B.F. Kiker, "The Economic Ideas of Thomas Cooper," B.F. Kiker and Robert J. Carlsson, eds., South Carolina Economists: Essays on the Evolution of Antebellum Economic Thought (Columbia, SC, 1969), pp. 44-46.
} 
until 1834. Cooper died five years later in Columbia, South Carolina. He was praised by Jefferson as "the greatest man in America in the power of the mind."7

Cooper's seminal economic treatise, Lectures on the Elements of Political Economy, was published in 1831 during the midst of the nullification crisis. In 1828 President John Quincy Adams signed into law the so-called Tariff of Abominations. The tariff galvanized Southern free traders and transformed tariff policy into a debate over the nature of representative government. Cooper's Lectures propelled him to the fore of the national discourse over trade policy. He became, along with Calhoun, the symbolic head of South Carolina's nullification movement. ${ }^{8}$

More than any other Southerner, Cooper merged laissez-faire and states-rights into a single doctrine. By doing so, he illustrated the intimacy between the political and the economic in Southern thought. Just so, he established in the antebellum discourse a defense of the negative state with an economic logic rooted in the philosophical skepticism of Smith. ${ }^{9}$ Like Smith, Cooper questioned man's capacity for rational thought. "Temptations, from caprice, from prejudice, from flattery, from temporary excitements...from imperfect apprehensions of the questions before them...[and] from sudden impulse," he wrote, drive humanity to irrational behavior and obscure comprehension of an enlightened self-interest. "When I was young," Cooper reminisced, "I took for granted, that every man, and every body of men, would act

\footnotetext{
${ }^{7}$ Quote found in Daniel Walker Howe, What Hath God Wrought: The Transformation of America, 18151848 (New York, 2007), p. 459. Cooper's other important works include, "The Scripture Doctrine of Materialism" (1823) and "A View of the Metaphysical and Physiological Arguments in Favor of Materialism" (1781), Udo Theil, ed., Philosophical Writings of Thomas Cooper: Miscellaneous Works, vol. III, (Bristol, 2001)

${ }^{8}$ Wilentz, The Rise of American Democracy, pp. 374-379; Schlesinger, The Age of Jackson, pp. 34, 95-96.

${ }^{9}$ Expressions of Smith's skepticism are found throughout his Theory of Moral Sentiments. For example, "The natural causes of things can not be entirely controlled by the impotent endeavors of man," a race, Smith argued, that is "allotted a humbler department...one much more suitable to the weakness of his powers, and to the narrowness of his comprehension." The Theory of Moral Sentiments (1759; reprint, New York, 1966), p. 239. And in the Wealth of Nations, "the sovereign is completely discharged from a duty, in attempting to perform which he must always be exposed to innumerable delusions, and for the proper performance of which his human wisdom of knowledge could never be sufficient." An Inquiry into the Nature and Causes of the Wealth of Nations (1776; reprint, New York, 1937), vol. II, p. 290.
} 
uniformly on the obvious motive of self-interest. I was mistaken. The fact is otherwise; not in a few, but in a majority of cases." 10

Cooper and Smith shared a cynicism toward the legislator's capacity to judge the interests of individuals. This skepticism served as a foundational principle for laissez-faire economics. Smith, however, never explicitly tied his philosophical skepticism to political theory. Cooper broadened the scope of Smithian laissez-faire to be inclusive of all policy-political, social, and economic. Cooper's suspicions of man's intellectual capacities were intensified in his discussion of elected officials. Legislators, Cooper wrote, "promiscuously chosen, who have neither the same means of minute information, the same imperious motives to use them, or the same experience," should exercise deference in economic matters, for "every man who has dedicated his whole time and attention to the business by which he supports himself and his family, must have more perfect and accurate knowledge."11

From this point Cooper constructed a case against the positive state. Having already attacked the practical value of legislative judgments, Cooper denied the moral and historical value of nations. The tendency of philosophers to exaggerate the importance of states by finding in them "some existing intelligent being" drew Cooper's ire. The state was simply a means to secure the well-being of individuals. "Every nation is composed of its individual citizens; the terms nation, state, community, are words merely-they do not denote any thing separate from the individual members whose aggregation and association has received these names."12 Nations

\footnotetext{
${ }^{10}$ Thomas Cooper, Lectures on the Elements of Political Economy (1831; reprint, New York, 1971), pp. 332-333.

${ }^{11}$ Thomas Cooper, Two Tracts: On the Alteration of the Tariff; and on Weights and Measures (Charleston, 1823), p. 5.

${ }^{12}$ Ibid., p. 5.
} 
were no more than associations of men, created to "protect nothing but the laws affording a common protection."13

In the antebellum economic discourse, Cooper offered the strongest case for the negative state. He combined philosophical skepticism and the discounting of state authority with two key economic principles. First, Cooper presented a narrow definition of what constituted national wealth. He argued national wealth was simply the aggregate of that which is possessed by individuals. "The wealth, the capital of every nation, is nothing else than the aggregate of the wealth and capital of the individuals who compose it." ${ }^{14}$ Second, his political economy was based on the "buy where you can buy cheapest" principle. "If I can buy of my neighbor any commodity, cheaper than I can make it at home, I save the difference of expense of buying it; and I am more profitably employed in making some exchangeable commodity for my neighbor. Cheaper than he can make it, then by making the article that I want from him." ${ }^{\text {"15 }}$ Cooper aimed to shape the economic and political narratives over the legal exercise of state authority. An individual-centered definition of wealth devalued the role of political institutions. And the "buy where you can buy cheapest" tenet undermined state prerogatives in establishing restrictions on trade.

By diminishing the role of the state Cooper united his political and economic thought. He also made nullification the natural adjunct of his version of laissez-faire. Restrictions on trade were contrary to economic logic, "founded on fraud, misrepresentation, and intrigue on the part of monopolists," and thus politically void. ${ }^{16}$ Cooper vilified protectionists and their supporters in Congress as perpetuators of legislative corruption. Neither represented political legitimacy.

\footnotetext{
${ }^{13}$ Cooper, Lectures on the Elements of Political Economy, p. 253

${ }^{14}$ Cooper, Two Tracts, p. 7.

${ }^{15}$ Ibid., p. 5.

${ }^{16}$ Cooper, Lectures on the Elements of Political Economy, p. 219.
} 
Protectionists were like any other special interest group, anathema to republicanism, damaging to individual liberty, and the executors of aristocracy in the modern age.

The anti-statism in Southern political economy corresponded to theoretical developments in the nineteenth-century laissez-faire movement. In the trans-Atlantic discourse, laissez-faire was increasingly wedded to liberal politics. In Britain, for instance, laissez-faire was associated with a larger set of values consistent to social, political, and economic freedoms. ${ }^{17}$ But Cooper's attachment to Southern institutions also drove him to articulate a version of laissez-faire without reference to industrialization. Moreover, he celebrated traditional agrarianism. "If any profession is to be fostered, let it be the tiller of the earth, the fountain head of all wealth, and all power, and all prosperity."18 "The whole system," Cooper wrote of manufactures, "tends to increase the wealth of a few capitalists, at the expense of the health, life, morals, and happiness of the wretches who labor for them...we want in this country, no increase of proud and wealthy capitalists." ${ }^{19}$ Cooper's agrarian brand of laissez-faire was an anomaly in the nineteenth-century discourse, especially after David Ricardo had championed industrial interests.

Cooper's tirade against industry symbolized the larger debate in antebellum literature over the trajectory of the American economy. During the middle decades of the antebellum period two incompatible national economic and political programs had emerged. Protectionists encouraged the rapid industrial development of the North. Southern free traders imagined a zerosum game, whereby Northern industrial development undermined the plantation economy and empowered Northern politicians with the legislative authority to hasten the demise of slavery. The Southern attachment to states-rights and free trade, and the intellectual and policy creation of

\footnotetext{
${ }^{17}$ Anthony Howe, "Restoring Free Trade: the British experience, 1776-1873," Donald Winch and Patrick K. O'Brien, eds., The Political Economy of British Historical Experience, 1688-1914 (Oxford, 2002), p. 212.

${ }^{18}$ Thomas Cooper, "Political Arithmetic, No. II" (1798), Udo Theil, ed., Thomas Cooper, Philosophical Writings: Political Essays, vol. II, p. 50

${ }^{19}$ Cooper, Two Tracts, p. 21.
} 
nullification as a viable option came in part as a response to the increasing influence protectionists wielded over trade policy. ${ }^{20}$ In their defense of Southern institutions, economic thinkers like Cooper drew on long-standing free-trade values that accentuated the political consequences of economic policy. In the antebellum period, the Southern version of laissez-faire evolved into one of the most important political challenges to federal authority. By doing so, the Southern free traders adapted an ideology initiated by the enlightened Smith and grounded in a compassionate moral philosophy to protect slavery.

More than any figure John Calhoun popularized in the public discourse the connection between laissez-faire economics and slavery. ${ }^{21}$ Born in 1782, Calhoun matriculated at Yale and the prestigious Tapping Reeve Law School in Litchfield, Connecticut. He had a long and distinguished career in national politics stretching from 1811 to his death in 1850 . He served terms in the House and Senate, was Vice President under two administrations, and was Secretary of War and State. He was one of the most important political figures of the middle period and the most sophisticated theoretician to serve in Congress. Under Jackson, he led South Carolina in the nullification crisis. It was then that Calhoun provided the intellectual foundation for Southern secession.

Calhoun loaded Cooper's economic analysis with political and sectional overtones. In speeches, papers and letters written during and after the nullification crisis, Calhoun integrated selective principles of laissez-faire into a tightly woven political doctrine. He developed an intellectual affinity for laissez-faire; but he was more concerned with the political ramifications of economic policy than its theoretical rationale. Calhoun employed the standard assumptions of laissez-faire as a defensive strategy aimed at preserving the South's economic and political

\footnotetext{
${ }^{20}$ Onuf and Onuf, Nations, Markets, and War, pp. 10, 174-182, 260-262.

${ }^{21}$ Richard Hofstadter's chapter on Calhoun is one of the significant pieces in the historiography. "John C. Calhoun: Marx of the Master Class," The American Political Tradition and the Men Who Made It (New York, 1948), pp. 86-117.
} 
significance in national affairs. Like Cooper, tariffs were the target of Calhoun's ire. Also like Cooper, Calhoun extended his criticisms of tariffs into an anti-statist and anti-industrial political economy.

The Tariff of Abominations was the catalyst in the development of Calhoun's economic thought. When the tariff was signed into law in 1828 the planter economy of South Carolina was reeling from western migration and exhausted soils. Calhoun wrote a friend that summer that "my property has ceased to give profits, which I believe is true of 9/10 of our planters." $22 \mathrm{He}$ nailed tariffs as the cause of this malaise. "The whole of our profits are intercepted at the customs House, through high duties on what we consume," Calhoun wrote. ${ }^{23}$ "We are the serfs of the system," Calhoun charged, "out of whose labor is raised, not only the money paid to the Treasury, but the funds, out of which are drawn the rich reward of the manufacture and his associates in interest. Their encouragement is our discouragement." 24

Like most Southerners, Calhoun saw the tariff through a sectional lens. The tariff, Calhoun figured, enriched the North at the expense of the South. It served as a bounty for Northern labor and a tax on Southern consumers. "The very acts, which imposes the burden on the consumers gives to the labor of one section the power of recharging and more than recharging the duty, which cannot be shifted to the shoulders of others." For every cent paid in tariffs Northern labor was awarded higher prices for their products and thus higher wages. "Almost every man to the North, let his employment be what it may...hopes to receive more from the tariff by the increased price of his labor, or his property than what he pays in duties, as a consumer." 25 Since trade was merely a transfer of commodities and labor, paying an additional

\footnotetext{
${ }^{22}$ John C. Calhoun to Samuel Ingham, July 23, 1828, Clyde N. Wilson, ed., The Papers of John C. Calhoun (Columbia, SC, 1977), vol. X, p. 402.

${ }^{23}$ John C. Calhoun to John McLean, July 10, 1828, Ibid, p. 397.

${ }^{24}$ John C. Calhoun, "Exposition and Protest," Ibid., p. 456.
} 
tax diminished the exchange value of Southern commodities and labor. This weakened the South's competitive advantage. Tariffs burdened the South with added costs on articles necessary in the production of staples, undermining the region's capacity to contend with foreign producers. Furthermore, by diminishing the number of goods imported into America, the tariff restricted access of cotton producers to foreign demand. Duties on imports were equivalent to taxes on exports. British textile manufacturers, Calhoun argued, would only consume in Southern cotton an amount equal to what Americans purchased in British wares. ${ }^{26}$

Calhoun's economic reasoning illustrates the sectional tone of Southern economic thought. Southerners believed the tariff made them dependent upon either heavily taxed British imports or Northern manufactures. The necessity, forced upon the South by tariffs, of having to resort to the latter incensed Calhoun. Legislation imposing habits of consumption to create pecuniary advantages for a specific class of producers reeked of privilege. "You compel an exchange with you by taxing our exchanges with the rest of the world..."27

With the theory of nullification Calhoun raised particular principles embedded in freetrade economics into a full-fledged political doctrine. In essence, he advocated an ideology that synthesized states-rights and laissez-faire. He interpreted tariff legislation as having grown from practical measures to stabilize the revenue and remit government debt into policies that doled out privilege to the North and enhanced the authority of national institutions. The tariff, Calhoun lectured Congress, "extracts from the South a large portion of the proceeds of its industry, which

\footnotetext{
${ }^{25}$ John C. Calhoun to Micah Sterling, September 1, 1828, Ibid., p. 415.

${ }^{26}$ On this point, see Calhoun's ally in Congress George McDuffie. "Speech of Mr. McDuffie Against the Prohibitory System," Southern Quarterly Review (November, 1831).

${ }^{27}$ John C. Calhoun to Samuel Ingham, October 30, 1830, Clyde N. Wilson, ed., The Papers of John C. Calhoun (Columbia, SC, 1978), vol. XI, p. 252.
} 
bestows upon the other sections, in the shape of bounties to manufactures." ${ }^{28}$ Calhoun added to his argument principles of classical republicanism. Excessive duties gave the national government revenue to spread patronage and ultimately corrupt the republican character of the American polity. It made no difference that tariff legislation was promulgated by a democratic legislature. According to Calhoun, majority rule was the most dangerous form of all governments. "No government, based on the naked principle, that the majority ought to govern, however true the maxim in its proper sense, under proper restrictions, ever preserved its liberty even for a single generation. ${ }^{, 29}$ Calhoun's constitutional reasoning brought him to nullification. The reserved rights of the states implied "a veto or control within its limits on the action of the General Government, on contested points of authority," or put simply, the right to nullification. ${ }^{30}$ Laissez-faire complimented other important factors in Calhoun's political philosophy. Like Cooper, he challenged the positive state. "That all governments are actuated by a spirit of ambition and avarice, and that there is a universal tendency in consequences to the abuse of power, be the form of government what it may, monarchical, aristocratical, or republican, and which, if unchecked, must lead to tyranny and oppression, is a truth so well established by uniform experience, that it may be considered an axiom in political science."31 Calhoun's distrust of government extended beyond the conventional republican fears of legislative abuse of power and corruption; like Smith he doubted the legislator's ability to manage the economy. ${ }^{32}$ Writing

\footnotetext{
${ }^{28}$ John C. Calhoun, "Speech on the Force Bill," The Papers of John C. Calhoun (Columbia, SC, 1978), vol. XII, p. 65; also, John C. Calhoun, "Speech on the Bill to Reduce the Duties on Certain Imports," February 23, 1837, The Papers of John C. Calhoun, vol. XII, p. 455.

${ }^{29}$ Merrill D. Peterson, The Great Triumvirate: Webster, Clay, Calhoun (Oxford, 1987), pp. 409-413.

${ }^{30}$ John C. Calhoun, “Exposition and Protests," The Papers of John C. Calhoun, vol. X, pp. 492, 506, 526.

${ }^{31}$ John C. Calhoun, "Rough Draft of an Address to the People of South Carolina," The Papers of John C. Calhoun, Vol. XI, p. 272.

32 On Calhoun's republicanism see Lacy Ford, "Republican Ideology in a Slave Society: The Political Economy of John C. Calhoun," The Journal of Southern History (August, 1988), pp. 421-422.
} 
in the Southern Quarterly Review, Calhoun cautioned, "In view of the errors to which legislators are subject...it appears to us that the benefits that may flow from it are more than counterbalanced by the ill consequences that may arise from unadvised attempts to foster an unnatural growth, which no care or protection can naturalize." However genuinely interested the impartial, seasoned legislator might be, the intricate webs of commerce spread throughout and beyond the American economy made any attempt at supervision impossible. "The ramifications of trade are so extensive, the circumstances that combine to make any manufacture in this or that position, likely to succeed, or the contrary, are so numerous, that it is altogether beyond the grasp of human intellect to adjust to nice calculation." 33

Calhoun's thought also reveals the dialectic between a staunch dedication to laissez-faire and a commitment to agrarianism. Southern free traders like Calhoun were part of an earlier eighteenth-century trans-Atlantic free-trade tradition grounded in agrarianism. ${ }^{34}$ Smith had decried the harmful social ramifications of industrial labor, and he noted the economic efficiencies of agricultural pursuits. ${ }^{35}$ Accommodating laissez-faire to manufacturing and machine-based systems of social production was hardly Smith's intention.

It was not until Ricardo's defense of manufacturers that an association between free trade and industrialization emerged. Ricardo's position was owed to historical circumstances then evolving in nineteenth-century Britain, much like the Southern commitment to free trade was determined by peculiarities in the American condition. Free trade in Britain was, according to

\footnotetext{
${ }^{33}$ John C. Calhoun, “The Tariff,” Southern Quarterly Review (April, 1842), pp. 514-515.

${ }^{34}$ Joyce Appleby, Capitalism and a New Social Order: The Republican Vision of the 1790s (New York, 1984), pp. 39-47; Allan Kulikoff, The Agrarian Origins of American Capitalism (Charlottesville, VA, 1992).

${ }^{35}$ Smith wrote, "The capital employed in agriculture, therefore, not only puts into motion a greater quantity of productive labor than any equal capital employed in manufactures, but in proportion, too, to the quantity of productive labor which it employs, it adds a much greater value to the annual produce of the land and labor of the country, to the real wealth and revenue of its inhabitants. Of all the ways in which a capital can be employed, it is by far the most advantageous to the society." Wealth of Nations, vol. II, p. 53.
} 
one historian, the product of "vast cultural dimensions." 36 Those credited with synthesizing the maxims of Smith, Malthus and Ricardo with the industrial order were not academics, but a mixbag of manufacturers and political entrepreneurs. When industrialists reckoned free trade in agriculture would cheapen the cost of British labor and thus make its manufactures less expensive, they launched a campaign that elevated laissez-faire to orthodoxy. ${ }^{37}$ British freetraders targeted the Corn Laws. By the early nineteenth century Britain's growing population and increases in domestic grain prices brought the Corn Laws to the fore of domestic politics. In 1839 free-trade activists organized the Manchester based Anti-Corn Law League. The League matured into a political machine the likes of which had never before been seen in Britain and shortly after its establishment spun off a subsidiary organization popularly known as the Manchester School of Economics. These two groups popularized laissez-faire in British intellectual and political culture and brought an air of respectability to the industrial sector. ${ }^{38}$ The campaign against the Corn Laws was provided further impetus by Parliamentarians interested in advancing the industrial superiority of Britain, or in the words of Joseph Hume, MP, "render all the world tributary to us." ${ }^{, 39}$ When the Corn Laws were repealed in 1846 it signaled a marked shift in public opinion over trade policy. ${ }^{40}$ From this point free trade was increasingly considered

\footnotetext{
${ }^{36}$ Howe, "Restoring free trade: the British experience, 1776-1873," p. 193; Donald Winch, Riches and Poverty: An Intellectual History of Political Economy in Britain, 1750-1834 (Cambridge, 1996).

${ }^{37}$ Bernard Semmel, The Rise of Free Trade Imperialism: Classical Political Economy, the Empire of Free Trade and Imperialism (Cambridge, 1970).

${ }^{38}$ William Grampp, The Manchester School of Economics (Stanford, 1960),p. 5; William Grampp, "How Britain Turned to Free Trade," The Business History Review (Spring, 1987), pp. 86-112; Norman McCord, The Anti-Corn Law League, 1838-46 (London, 1953); Paul Pickering and Alex Tyrrell, The People's Bread: A History of the Anti-Corn Law League (London, 2000).

${ }^{39}$ Semmel, The Rise of Free Trade Imperialism,p. 148.

${ }^{40}$ Howe, "Restoring free trade: the British experience, 1776-1873;" Richard Teichgraeber, 'Free Trade' and Moral Philosophy (Oxford, 1988); Grampp, "How Britain Turned to Free Trade," pp. 86-112.
} 
the policy most effective at developing Britain's industrial economy, and has since affixed laissez-faire ideology to the industrial order.

While free trade metamorphosed into a doctrinal instrument of modern industrialism in Britain, in the South it was attached to an agrarian regime. Conversely, the landed aristocracy in Britain defended tariffs with arguments against laissez-faire ideology that mirrored almost verbatim those employed by antebellum protectionists, the difference being that American protectionists championed industrialization. ${ }^{41}$ These differences indicate both the variance attendant to ideas in their historical context, as well as the malleability of nineteenth-century political economy to serve divergent interests. Southern free traders borrowed concepts from British classicists, but only those that suited their particular regional context.

Like Cooper, Calhoun pushed the Southern free-trade movement against industry and away from the style and purpose of free trade in the Mancunian tradition. Calhoun also tied his defense of slavery to agrarianism, which the rapidly industrializing North increasingly challenged. At the same time, industry, according to Southern doctrine, also undermined the republican experiment by radicalizing the working class and destroying America's social structure. On the floor of the Senate Calhoun warned of the dangers posed by the twin evils of industrialization and urbanization. "I hold then, that there has never existed a wealthy and civilized society in which one portion of the community did not, in point of fact, live on the labor of the other." 42 Wages would sink below levels of subsistence, until civil strife descended on the North, "between the capitalists and operatives for into these classes it must, ultimately, divide society. The issue of the struggle here, must be the same as it has been in Europe."43 Northern

\footnotetext{
${ }^{41}$ Anna Gambles, Protection and Politics: Conservative Economic Discourse, 1815-1852 (Suffolk, U.K., 1999), pp. 42, 51, 69, 77, 183-185, 207, 217-218.

${ }^{42}$ John C. Calhoun, "On the Reception of Abolitionist Petitions," February 6, 1837, Richard K. Cralle, ed., The Works of John C. Calhoun, vol. II(New York, 1854), p. 631.

${ }^{43}$ Calhoun, "Exposition and Protest," The Papers of John C. Calhoun, vol. X, p. 480.
} 
workers were quickly realizing their condition was comparable to, if not worse than the chattel slave. Leveling elements would inevitably seize the private property of all Americans. These fears prompted Calhoun to propose a partnership between conservative 'gentlemen' of the North and Southern planters. Southerners would work to silence labor if Northern capitalists helped hush abolitionists.

There was, however, more to Calhoun's proposed union between Northern capital and Southern slaveholders. Calhoun's version of laissez-faire was compatible with classical republicanism. He feared most an alliance between capitalists-manufacturers and bankers for Calhoun-and the federal government. As Lacy Ford has pointed out, "Calhoun fought in defense of economic liberalism against a potentially reactionary alliance of government and capital." He dreaded equally the revolutionary inclinations of industrial workers as he did the ability of capital, wielding the powerful arm of state, to exploit the working class and subvert the republican nature of American government. ${ }^{45}$

Calhoun's Tory-like disparaging of industrialization, couched in a Jeffersonian agrarian idealism, represented a prominent strain in the American free-trade tradition. ${ }^{46}$ It compels historians to refigure conventional associations between laissez-faire and industrial capitalism. The Southern version of laissez-faire was not, in twenty-first-century parlance, anti-capitalist. But it was aimed at perpetuating economic institutions as they existed, resisting the forces of economic modernization, and thwarting the North's desire to catapult America into the industrial age.

In the antebellum economic discourse the champions of free trade provided some of the strongest arguments against industrialization. The relationship between Southern laissez-faire

\footnotetext{
${ }^{44}$ Ford, "Republican Ideology in a Slave Society," p. 421.

${ }^{45}$ Hofstadter, The American Political Tradition, p. 86.

${ }^{46}$ Hartz, The Liberal Tradition in America, p. 197.
} 
and agrarianism marks a breach between the domestic free-trade movement and British classicism. American freetraders followed an alternative course in the intellectual and historical development of laissez-faire political economy as it passed from Smith to Ricardo. In short, laissez-faire in the American discourse broke from the British authorities.

In antebellum America there co-existed two forms of laissez-faire ideology that were fundamentally incompatible with each other.If the United States did indeed symbolize in practical terms the ideal of free-trade economy, the nation did not harbor a singular, synthesized expression of free-trade ideology, rather there were multiple articulations. Neither did America's free-trade political economists conform to the widely recognized theoretical authorities of the trans-Atlantic laissez-faire tradition. The Southerners in particular, existed on an isolated laissez-faire intellectual plane. Although the Southern free traders adopted a more secular methodology, something the Northeastern academics were reluctant to do, the Southern version of laissez-faire failed to incorporate the values of the Mancunian tradition. Neither did it emphasize Smithian moral philosophy. The highly politicized nature of Southern thought compelled men like Cooper and Calhoun to engage the laissez-faire discourse pursuant of interests and ideas that were radically different from all other nineteenth-century free-trade political economists.

The American free-traders were, in this way, awkwardly arranged. The Northeastern brand was bound to an intellectual tradition that by the early nineteenth-century had largely expired. And the Southerners, prone to resourceful theoretical inventiveness, chartered their own laissez-faire course. Although the origins of both the Northeastern and Southern free-trade brands were Smithian neither maintained an absolute commitment to the Scotsman, and they were less interested in devoting themselves to the British authorities who succeeded Smith.

The latter is exhibited in the following chapter. Antebellum Americans were obstinate in their treatment of Thomas Malthus and David Ricardo. Like the Northeastern and Southern packaging of Smith, the Americans who reviewed Malthus and Ricardo were not theoretical 
purists; they manipulated, detracted, and essentially rejected the British giants. The belief in American exceptionalism, which almost every antebellum American subscribed to, inhibited domestic thinkers from consenting to the sometimes apocalyptic forecasts of Malthus and Ricardo. In consequence, a distinctly American political economy emerged; one that did not depend on tradition, nor seek out intellectual precedent. American free-trade literature discovered its own discourse, suited to the American experience and fit for the American mind. 


\section{Chapter IV}

Progress and Poverty: Malthus and Ricardo in America

The flexibility of Adam Smith's principles facilitated the accommodation of laissez-faire to the cultural traditions of both the Northeastern and Southern free-traders. Thomas Malthus and David Ricardo, however, took laissez-faire in a new direction, one that did not easily conform to American intellectual traditions. Most antebellum Americans rejected the pessimism inherent to the economic reasoning of Malthus and Ricardo. Domestic conditions simply denied the dismal forecasts of Malthus and Ricardo. This chapter will review the American treatment of Malthus and Ricardo during the antebellum era, with special emphasis given to those who wrote in the laissez-faire paradigm.

Smith launched political economy into the mainstream of the trans-Atlantic public sphere. In 1805 , the first academic post in the world bearing the name of the nascent science was established at the East India College in Hertfordshire, England. The position was awarded to Thomas Malthus. Malthus was born in the 1766 in south England. At eighteen he enrolled at Jesus College, Cambridge for a career in the clergy. Shortly after graduation, Malthus was ordained in the Church of England. He became something of a celebrity following the 1798 publication of his Essay on the Principle of Population. ${ }^{1}$ The work went through six editions during Malthus' lifetime, each with important revisions that reflected contemporary criticisms of the book as well as changes in Malthus' perspective. He published several other works in political economy, but he is largely remembered for his work on population.

\footnotetext{
${ }^{1}$ For an overview of Malthus's career and writings see Donald Winch, Riches and Poverty: An Intellectual History of Political Economy in Britain, 1750-1834 (Cambridge, 1996), chapters 8-12; Charles Gide and Charles Rist, History of Economic Doctrines: From the Time of the Physiocrats to the Present Day (1913; reprint, New York, 1915), pp. 119-121; Robert Heilbroner, The Worldly Philosophers: The Lives, Times, and Ideas of the Great Economic Thinkers (New York, 1999), pp. 82-86.
} 
In the Essay, Malthus condemned much of humanity to a life of depravity and melancholy. Providence arranged natural laws without regard to the happiness of humanity, Malthus concluded. The most insensitive and pressing of nature's dictate was the rapidity with which humanity populates the earth and the inability of the food supply to keep pace."These two laws," Malthus wrote, "ever since we have had any knowledge of mankind, appear to have been fixed laws of nature; and, as we have not hitherto seen any alteration in them, we have no right to conclude that they will ever cease to be what they are now."2 Man increases its numbers geometrically, but the means of subsistence increase by arithmetical progression, or simple addition. Confronted with this ominous calculation, Malthus penned what has become his most famous passage:

A man who is born into a world already possessed, if he cannot get subsistence from his parents on whom he has a just demand, and if society do not want his labor, has no claim of right to the smallest portion of food, and, in fact, has no business to be where he is. At nature's mighty feast there is no vacant cover for him. She tells him to be gone, and will quickly execute her own orders, if he do not work on the compassion of some of her guests. If these guests get up and make room for him, other intruders immediately appear demanding the same favor. The report of a provision for all that come fills the hall with numerous claimants. The order and harmony of the feast is disturbed, the plenty that before reigned is changed into scarcity; and the happiness of the guests is destroyed by the spectacle of misery and dependence in every part of the hall, and by the clamorous importunity of those who are justly enraged at not finding the provisions which they had been taught to expect. The guests learn too late their error, in counteracting those strict orders to all intruders, issued by the great mistress of the feast, who, wishing that all guests should have plenty, and knowing that she could not provide for unlimited numbers, humanely refused to admit fresh comers when her table was already full. ${ }^{3}$

Malthus predicted little better for the United States. In America, where labor was well compensated, the masses might avoid immediate suffering, but, he cautioned, "It may be expected that in the progress of the population of America, the laborers will in time be much less

\footnotetext{
2 Thomas Malthus, An Essay on the Principle of Population (1798; reprint, Oxford, 1993), pp. 12-13.

${ }^{3}$ Thomas Malthus, An Essay on the Principle of Population (London, 1803), p. 531. This paragraph was omitted from the 1806 edition.
} 
liberally rewarded. The numbers will in this case permanently increase, without a proportional increase in the means of subsistence."4

Malthus was widely referenced in the antebellum discourse, but with few exceptions, Americans rejected Malthusian population theory. Malthusian population theory was not, however, in the words of one historian, "a side attraction." Antebellum free traders accepted Malthus as a central figure in British laissez-faire, but they developed an independent logic based on the belief that American conditions existed without historical precedence. ${ }^{6}$ Antebellum free traders integrated a distinctly American understanding of population growth into a wider defense of laissez-faire. In the antebellum discourse, laissez-faire was not rigidly confined to the strictures of a single paradigm. Rather Americans engaged laissez-faire with a sense of intellectual autonomy. ${ }^{7}$ The Americans recognized that some principles of British classicism suited the domestic context, while other principles did not. This was particularly the case in the South where Malthusianism was manipulated to vindicate the region's social, political, and economic institutions. ${ }^{8}$ It was not uncommon, however, for Southerners who were sympathetic to Malthusianism to simultaneously reject other tenets of classical doctrine. The American

\footnotetext{
${ }^{4}$ Malthus, An Essay on the Principle of Population, p. 58. 1798 edition.

${ }^{5}$ George Johnson Cady, “The Early American Reaction to the Theory of Malthus," The Journal of Political Economy (October, 1931), p. 632.

${ }^{6}$ On the relationship between Malthusianism and Smithian laissez-faire see Winch, Riches and Poverty, pp. 224, 269.

${ }^{7}$ Joseph Spengler's assessment that the Americans misunderstood Malthusianism is not accurate. "Population Doctrines in the United States, I: Anti-Malthusianism," The Journal of Political Economy (August, 1933), p. 435. Charles Dunbar initiated in the historiography the argument that antebellum political economists contributed nothing to the science, "Economic Science in America, 1776-1876," The North American Review (January, 1876), pp. 137, 140, 146. Dunbar's argument was repeated by Joseph Schumpeter, History of Economic Analysis (Oxford, 1954),pp. 514, 519. And more recently by A.W. Bob Coats, On the History of Economy Thought, "American Economic Thought" (London, 1992), p. 342.

${ }^{8}$ Joseph Spengler, "Population Theory in the Ante-Bellum South," The Journal of Southern History (August, 1936), p. 362.
} 
treatment of Malthus was remarkably varied and illustrative of the malleability of laissez-faire in the antebellum discourse.

Benjamin Franklin's 1751 "Observations Concerning the Increase of Mankind and the Peopling of Countries" was the first serious attempt made by an American to deal with population theory. ${ }^{9}$ American conditions, Franklin argued, prevented redundant numbers. Even if the population doubled every 25 years, a rate calculated by Franklin and one that proved true until the Civil War, there was no need to fear overpopulation. "Notwithstanding this increase," Franklin wrote, "so vast is the territory of North America, that it will require many ages to settle it fully..."10 With a seemingly infinite supply of land, labor would not compete for dwindling resources. Rather wages would be kept high enough to afford a decent standard of living. "A laboring man," Franklin found, "can in a short time save money enough to purchase a piece of new land...whereon he may subsist a family." "11 Rules suitable for Europe, Franklin concluded, were inapplicable to America. ${ }^{12}$ Thus, population studies "formed on observations, made on fullsettled old countries, as Europe," Franklin wrote, "will not suit new countries, as America."13

Franklin's ideology was more pragmatic than dogmatic, and he was hardly a laissez-faire type. Still, Franklin set the tone for antebellum treatment of population theory. The underlying tenet that motivated the breach between the Americans and Malthus was American

\footnotetext{
${ }^{9}$ James Gibson, Americans versus Malthus: The Population Debate in the Early Republic, 1790-1840 (New York, 1989), p. 27.

${ }^{10}$ Benjamin Franklin, "Observations Concerning the Increase of Mankind and the Peopling of Countries" (1755), Jared Sparks, ed., Essays on General Politics, Commerce and Political Economy (1836; reprint, New York, 1971), p. 313.

${ }^{11}$ Franklin, "Observations Concerning the Increase of Mankind and the Peopling of Countries," p. 313.

${ }^{12}$ On the belief in exceptionalism in American intellectual history see Dorothy Ross, The Origins of American Social Science (Cambridge, 1991); Seymour Lipset, American Exceptionalism: A Double-edged Sword (New York, 1996); Deborah Madsen, American Exceptionalism (Jackson, MS, 1998); Jonathan Glickstein, American Exceptionalism, American Anxiety: Wages, Competition, and Degraded Labor in the Antebellum United States (Charlottesville, VA, 2002).

${ }^{13}$ Franklin, "Observations Concerning the Increase of Mankind and the Peopling of Countries," p. 311.
} 
exceptionalism. By emphasizing American exceptionalism, the antebellum free traders signaled their willingness to pursue an alternative economic narrative. On some occasions, the belief in American exceptionalism led to sacrificing the internal consistency of their logic. If free-trade political economy delineated axioms applicable to all, then historical conditions were immaterial. But the Americans acknowledged the potential for some laws, in this case population, to bend according to prevailing circumstances. The natural order could be compromised, and the otherwise holistic system of laissez-faire political economy be made to account for the American experience. $^{14}$

The belief in American exceptionalism dominated Northern treatment of Malthus. Northeastern clergy freetraders rejected Malthus for its apparent skepticism in God's benevolence. ${ }^{15}$ Protectionists countered Malthus with an explicitly optimistic vision of American economic development. ${ }^{16}$ The protectionist rejection of Malthus was based on several points of criticism. First, protectionists quelled contemporary anxieties by arguing that even if the Malthusian trap was possible, overpopulation was not "for centuries to come." ${ }^{\text {"17 }}$ Few antebellum Americans could find any benefit in restricting domestic population growth. ${ }^{18}$ Besides, western

\footnotetext{
${ }^{14}$ Sidney Sherwood, "Tendencies in American Economic Thought," Johns Hopkins Studies $\left(15^{\text {th }}\right.$ series, 1897), p. 10.

${ }^{15}$ Michael O'Connor, Origins of Academic Economics in the United States (New York, 1974), p. 160. Spengler, "Population Theory in the Ante-Bellum South," p. 36. Reverend Samuel P. Newman's (17971842) The Elements of Political Economy (1835; reprint, Clifton, NJ, 1973) is illustrative of the Northern anti-Malthusian tone, pp. 254-256. See also Francis Wayland, The Elements of Political Economy (New York, 1837), pp. 339-340.

${ }^{16}$ Gibson, Americans versus Malthus, argues that the Americans met Malthus with the machine. Americans perceived industrialization as the harbinger of unprecedented growth, and thus, capable of sustaining large populations. Edmond Cocks, "The Malthusian Theory in Pre-Civil War America: An Original Relation to the Universe," Population Studies (March, 1967), pp. 351-352; Spengler, "Population Doctrines in the United States, I: Anti-Malthusianism," pp. 437-439.

${ }^{17}$ Francis Bowen, The Principles of Political Economy Applied to the Condition, and the Resources of the American People (1856; reprint, New York, 1974), p. 141.

${ }^{18}$ John Roscoe Turner, The Ricardian Rent Theory in Early American Economics (New York, 1921), pp. 34,112 .
} 
lands provided a 'safety-valve' for redundant labor. Second, Malthus considered each increase in humanity as an addition to the pool of consumers, but he failed to calculate the potential each human addition had for increasing production levels. Population pressures spurned Americans toward greater industry, advanced specialization, led to the mechanization of labor, and ultimately a more effective cultivation of the soil. Combined, these developments occasioned higher yields and higher wages. ${ }^{19}$ Population density was not something to fear; rather it was a reflection of American progress. The future promised higher standards of living as production gains would outpace population numbers. ${ }^{20}$ Or, put differently, the accumulation of capital would outpace population growth. Finally, protectionists argued that Malthusian overpopulation was evident only in countries with corrupt political and social institutions. ${ }^{21}$ The European masses faced a population crisis because their governments were instruments of the aristocracy. Reared in aristocratic England, Malthus was incapable of imagining the benefits afforded to ordinary citizens under a democratic-republican regime. For protectionists, democratic legislation was the cure to all economic evils. ${ }^{22}$

Northern optimism on American population growth was carried into the antebellum South by J.D.B. De Bow, a central figure in Southern political economy. Born in Charleston in 1820 , he moved to New Orleans as a young man where in 1846 he established the popular journal that carried his name. Two years later he was appointed professor of commerce and statistics at the University of Louisiana (Tulane). In 1853 De Bow was made head of the United States

\footnotetext{
${ }^{19}$ Alexander Everett, New Ideas on Population with Remarks on the Theories of Malthus and Godwin. With the addition of the correspondence between Everett and George Tucker on the Malthusian Theory, published in The Democratic Review for 1845 and 1847 (1827; reprint, New York, 1970), p. 40.

${ }^{20}$ E. Peschine Smith, A Manual of Political Economy (1853; reprint, New York, 1974),pp. 50-75. Protectionist optimism, and especially their refutation of diminishing returns, is highlighted in chapters 6 and 7 below.

${ }^{21}$ Daniel Raymond, The Elements of Political Economy (1823; reprint, New York, 1964), vol. II, p. 71-80.

${ }^{22}$ On this point, see Daniel Raymond, Thoughts on Political Economy (Baltimore, 1820),pp. 88, 129, 367368,379 .
} 
census. His three-volume The Industrial Resources, Statistics, \&c, of the United States and More Particularly of the Southern and Western States published in 1854 was a monumental achievement in statistical economics. ${ }^{23}$

A Southern nationalist and a staunch supporter of slavery, De Bow's chief concern was advancing the economic interests of the South. De Bow illustrated how a devotion to regional interests combined with a general optimism in antebellum conditions shaped the Southern treatment of Malthus. Although dedicated to laissez-faire principles, his economic philosophy maneuvered around the Malthusian trap. The republican nature of America's polity cultivated particular "habits" that engendered a robust industrious spirit, he believed. Southerners were compensated for their virtuous commercial and industrial character with augmented provisions of capital and increased wages. Thus, labor and capital were afforded a constant improvement in their condition. ${ }^{24}$

Southern free traders like De Bow broke from the British classical tradition in significant ways. They operated on a fundamentally different understanding of the natural order. In the process they effectively established a radically different paradigm distinguished by a genuinely Southern appreciation of economic phenomena. De Bow's enthusiasm over the development of the Southern economy was couched in a sectional tone. The natural order, De Bow argued, issued laws "just as fixed and unalterable as those that presided over the motions of planetary masses, or that regulate chemical affinities." 25 But for the South, nature's system did not promise the dismal circumstance described by Malthus. Indeed, the natural order, at least as it existed in the South, offered charitable bounties. De Bow discovered an alternative state of nature in the

\footnotetext{
${ }^{23}$ Eric Walther, The Fire-Eaters (Baton Rouge, 1992), pp. 204-205; Spengler, "Population Theory in the Ante-Bellum South," p. 373.

${ }^{24}$ J.D.B. De Bow, "Notes on Political Economy," De Bow's Southern and Western Review (October, 1855), pp. 422-423.

${ }^{25}$ J.D.B. De Bow, The Industrial Resources, Statistics, \&c. of the United States and More Particularly of the Southern and Western States (1854; reprint, New York, 1966), vol. I, p. 12.
} 
antebellum South. The laws governing the Southern universe were benign, providing opportunity rather than peril.

This appreciation was grounded in Southern optimism. Southerners had perfected the exploitation of nature. "Speed the plow" De Bow ordered, "raise the capacity of the earth, say we, to satisfy the requisitions of a rapidly augmenting population." Southern labor commanded nature's treasures, accumulated a vast reserve of capital, and evaded the population crisis that troubled Malthus. "The innate faculty of our people to subdue the physical world, their energy and self-reliance, their habitual disregard of discomfort, difficulties and dangers, have made other nations say of us, that we alone could instill heroism in the common pursuits of life." De Bow touted the industrious spirit of Southerners and celebrated the region's natural resources. "Let two blades of grass shoot up where but one grew before. Let one man conduct the previous operations of two men." 26

De Bow's economic thought captures Southern political economy in many ways. Although he rejected the Malthusian paradigm for the South, he saw the North in darker terms. De Bow is illustrative, in the words of his biographer, of one "reared in an era when the South grew conscious and fearful of its inferior position in the union." 27 Employing Malthusianism as an intellectual strategy to defend Southern institutions, he considered the population of the industrial North moving inevitably toward redundancy. "The mining and manufacturing operatives of the North...labor there from early dawn until after candle-light, from one year to another, for a miserable pittance, scarcely above the starvation point and without hope for

\footnotetext{
${ }^{26}$ Ibid., vol. I, p. 69.

${ }^{27}$ Ottis Clark Skipper, “J.D.B. De Bow, the Man,” The Journal of Southern History (November, 1944), pp. 404-423.
} 
amelioration. ${ }^{28}$ But in the South, slavery provided a social and economic safety-valve. ${ }^{29}$ The region's slave-based agrarian economy inhibited the development of industry and thus prevented the Malthusian cycle from operating. Slavery raised wages for Southern white workers, raised the status of free labor in the South, and precluded Southern labor from finding "employment in crowded cities and...competition in close and sickly workshops and factories, with remorseless and untiring machinery., ${ }^{30}$

The peculiar uses of Malthusianism in the South found another clear expression in George Tucker. Tucker was born into a prominent merchant family in Bermuda in 1775 . He moved to Virginia to study law under the tutelage of his uncle, St. George Tucker. He later served six years in Congress between 1819 and 1825 and was appointed by Thomas Jefferson to professor of moral philosophy at the University of Virginia. ${ }^{31}$ Tucker died in 1861 just two days before the attack on Fort Sumter.

Like De Bow, Tucker failed to recognize nineteenth-century convention that bound Malthus with laissez-faire universalism. Early in his career, Tucker offered what stood as the earliest critique of Malthus, only to have later, in the words of one historian, "out-Malthus Malthus." ${ }^{32}$ His version of laissez-faire was malleable, driven by a will to defend the South's

\footnotetext{
${ }^{28}$ J.D.B. De Bow, "The Non-Slaveholders of the South: Their Interest in the Present Sectional Controversy Identical with that of the Slaveholders," De Bow's Southern and Western Review (January, 1861), p. 72; Ross, The Origins of American Social Science, p. 32

${ }^{29}$ Malthus was an abolitionist. When Malthus learned his earlier appraisals of slavery's effect on Africa's populations were being used by anti-abolitionists in Parliamentary debates he rushed to press an appendix to the third edition of his Essay in order to advance the cause of British abolitionists and, in his own words, "rescue my character from the imputations of being a friend of the slave trade." Quote found in Seymour Drescher, The Mighty Experiment: Free Labor versus Slavery in British Emancipation (Oxford, 2002), p. 43.

${ }^{30}$ De Bow, "The Non-Slaveholders of the South,” p. 72.

${ }^{31}$ James Fieser, ed., The Life and Philosophy of George Tucker (Bristol, 2004), vol. II, pp. vii-xiv; Tipton Snavely, George Tucker as Political Economist (Charlottesville, VA, 1964), pp. 1-3; Leonard Helderman, "A Social Scientist of the Old South," The Journal of Southern History (May, 1936), p. 151.
} 
peculiar institution. Tucker's economic thought is indicative of the Southern tendency to avoid theoretical discipline, as well as the inability of American freetraders to formulate a consensus. "The laws of population, as laid down by Malthus must be considerably modified," Tucker wrote, for "it is clear, then, that moral causes-probably by producing a slight retardation of marriage-constitute the operative check in the United States, and that the extraordinary facility of subsistence which exist here, seems to exert no influence."33 His early criticisms of Malthus rested on a belief in a benevolent system of natural liberty. "Liberty seems to have been productive of so much good in whatever it has been fairly tried....that we are encouraged to hope it would not occasion a mischievous excess of population." ${ }^{34}$ Tucker's natural economic order was markedly different from that described by Malthus. Large populations stimulated human progress through increased specialization, a more effective exploitation of markets, and by encouraging literature and the fine arts. The whiggish tone of Tucker's thought was combined with American exceptionalism. The young nation existed in unprecedented historical circumstances. "There is seldom a day that the most indigent person among us does not eat animal; and it is next to impossible for many to suffer seriously here from the want of employment." ${ }^{35}$ He attributed these conditions to the prudent character of America's republican citizenry. Population checks in America operated as subtle, voluntary social forces. In short, the American experiment was atypical.

Tucker's population theory grew more Malthusian as tensions between North and South intensified. Tucker's optimism was replaced by Malthusian fatalism in a set of correspondences

\footnotetext{
${ }^{32}$ Spengler, "Population Theory in the Ante-Bellum South," p. 362.

${ }^{33}$ George Tucker, Progress of the United States in Population and Wealth in Fifty Years With an Appendix Containing an Abstract of the Census of 1850 (1855; reprint, New York, 1964), pp. iii, 27.

${ }^{34}$ George Tucker, "On Density of Population," Essays on Various Subjects of Taste, Morals, and National Policy (Georgetown, 1822), p. 82.

${ }^{35}$ Ibid., p. 76.
} 
with the well-known Boston protectionist Alexander Everett, a Northern anti-Malthusian. These were published in the late 1840s and widely circulated in Everett's Democratic Review. "I have read much, and thought much, on the subject," Tucker wrote, "and have persuaded myself that...Malthus's premises are in the main true..." ${ }^{36}$ Tucker struck a Malthusian tone with Everett, arguing that the natural limitations on fertile land coupled with humanity's propensity to multiply would depress labor to subsistence levels. With civilization came decay as redundant numbers exerted a slow, agonizing effect on the food supply; passing from animal, to vegetable, to grain, and eventually potatoes. "Food cannot go on increasing," Tucker reasoned. ${ }^{37}$ Labor would suffer disproportionately as provisions dwindled to a quantity barely able to support life. ${ }^{38}$

Other Southerners, mainly Thomas Cooper and Thomas Roderick Dew, were more consistent in their application of Malthusianism to fit the Southern narrative. Southern political economists, according to Dennis Hodgson, "were attracted to Malthusianism...because it allowed them to project a bleak future for the "free-labor' system." 39 As the nation drew closer to Civil War Southerners manipulated Malthusian logic and laissez-faire principles to argue the failure of free-labor society and bolster the legitimacy of Southern slavery. ${ }^{40}$ Cooper engaged the latter

\footnotetext{
36 "The Malthusian Theory Discussed in a Correspondence between Alexander Everett and Prof. George Tucker May 14, 1844" (1845), in Everett, New Ideas on Population with Remarks on the Theories of Malthus and Godwin, p. 298. Tucker restated his Malthusian position in his 1859 Political Economy for the People (New York, 1970), "As population advances, and the means of subsistence become comparatively more difficult of attainment, a portion of the community must pass from a dearer to a cheaper mode of subsistence, or the population must become stationary," p. 80.

37 “The Malthusian Theory Discussed in a Correspondence between Alexander Everett and Prof. George Tucker," in Everett, New Ideas on Population with Remarks on the Theories of Malthus and Godwin, p. 299.

${ }^{38}$ See also George Tucker, The Laws of Wages, Profits and Rents Investigated (1837; reprint, New York, 1964), pp. 32, 117-120, 155.

${ }^{39}$ Dennis Hodgson, "Malthus' Essay on Population and the American Debate over Slavery," Comparative Studies in Society and History (October, 2009), p. 748.

${ }^{40}$ Laurence Shore, Southern Capitalists: The Ideological Leadership of an Elite, 1832-1885 (Chapel Hill, NC, 1986), pp. 26-28; Hodgson, "Malthus' Essay on Population and the American Debate over Slavery," pp. $744,747$.
} 
tactic, as we saw in chapter 3, in writings during the nullification crisis. On population, Cooper warned that man's “tendency to increase is a law of nature: it may be checked, controlled, counteracted: by natural causes, by artificial means; but it can not be stopped." Cooper wrote in contrast to the prevailing optimism of antebellum culture, "if there be more human beings than food to support them, some of them must starve." ${ }^{41}$

In Cooper's political economy Malthusianism fit neatly into his larger narrative of the failure of Northern society and the moral superiority of slavery. Slavery acted as a positive check against overpopulation. ${ }^{42}$ Northern free society allowed its mud-sills to multiply with wanton rapidity, but in the South masters managed slave numbers and, if necessary, restricted their generation. Furthermore, because capital (master) in the South owned its labor, the slaveholder was more likely afford slaves a decent subsistence to labor since by doing so he improved his own assets. ${ }^{43}$

Thomas Roderick Dew developed Southern Malthusianism into a formidable defense against state-sponsored regulation of slavery. Born in 1802 into prominent a Virginian slaveowning family, by the 1830s Dew was, in words of one biographer, a "Southern touchstone" of pro-slavery philosophy. ${ }^{44}$ In 1827 Dew returned to his alma matter of William and Mary as professor of history, metaphysics and political economy. ${ }^{45}$ He was elected president of the college the following year and served in this capacity until his death in 1846. A free-trade

\footnotetext{
${ }^{41}$ Thomas Cooper, Lectures on the Elements of Political Economy (1831; reprint, New York, 1971), pp. $273,276$.

${ }^{42}$ Joseph Spengler, "Population Doctrines in the United States. II.Malthusianism," The Journal of Political Economy (October, 1933), p. 646.

${ }^{43}$ Hodgson, "Malthus' Essay on Population and the American Debate over Slavery," pp. 747-751.

${ }^{44}$ Lowell Harrison, "Thomas Roderick Dew: Philosopher of the Old South," The Virginia Magazine of History and Biography (October, 1949), p. 390.

45 Joseph Dorfman, The Economic Mind in American Civilization, 1606-1865 (New York, 1946),vol. I, pp. 895-896.
} 
fundamentalist, Dew instructed his students from the Wealth of Nations. "The South," one historian writes, "sat in his classroom and was told what to think."

Dew's population theory advanced an anti-statist, laissez-faire maxim that aimed at justifying the Southern slave prerogative. He employed Malthusian rationale to strike at federal and state legislation to regulate slavery. For Dew, Malthus provided evidence of the authority of market outcomes. The free-trade regime was not only nature's prescribed economic order, but it was also consistent with Southern slave interests. ${ }^{47}$ The principles of laissez-faire, Dew argued, "may truly be compared to the great law of gravity in the material world; powerful in its agency, frequently counteracted by other forces, but in consequence of its constancy and steadiness of its operation, overcoming every other power in the end. ${ }^{, 48}$ The slave population adjusted to a natural economic order that was beyond the scope of legislatures, thus statutes designed to check the slave population would be countered by natural, market-oriented directives.

Dew's understanding of population growth was communicated in his Review of the Debate in the Virginia Legislature of 1831 and 1832. He argued against a proposal to collect funds intended for purchase of the state's slaves for future deportation or colonization. Since, according to Dew, "Malthus has clearly shown population depends on the means of subsistence" the sluggish pace at which Virginia's white population increased would grind to halt, as taxes diminished the availability of the basic necessities. State-sponsored purchases of slaves would instead augment demand, luring enterprising masters to breed slaves at prodigious rates, thus counteracting the purpose of legislation. "The energies of government," Dew charged in the

\footnotetext{
${ }^{46}$ Michael O'Brien, Conjectures of Order: Intellectual Life and the American South, 1810-1860 (Chapel Hill, NC, 2004), vol. II, p. 888.

${ }^{47}$ Shore, Southern Capitalists, pp. 26-27.

${ }^{48}$ Thomas Dew, Lectures on the Restrictive System (1829; reprint, New York, 1969),p. 30.
} 
Virginia legislature, "are for the most part feeble or impotent" in their attempts to counter the inexorable natural economic order. ${ }^{49}$

As the Civil War drew closer, Dew and other laissez-faire Southerners increasingly adapted Malthusianism to their own ends. They employed the logic of Malthusian population theory to highlight the positive effects slavery had on mitigating redundant numbers. American political economists made more profound adjustments in their treatment of Ricardo ${ }^{50}$ By the mid-nineteenth century reputable political economists could not write on economic matters without discussing Ricardo. "Ricardo's influence on economic thought in the United States of the nineteenth century," Joseph Dorfman wrote, “was enormous." ${ }^{, 51}$ Dorfman's assessment glosses over the intricacies of the antebellum economic discourse. Antebellum free-traders treated Ricardo in a similar fashion to how they handled Malthus. Southerners balked at accepting the totality of Ricardo's doctrine, while most Northerners were unable to find a practical application of Ricardian principles in the American economic environment. The lack of intellectual commitment to Ricardo is further indication that British classicism did not dominate the domestic discourse. By the middle decades of the antebellum period the Americans developed a sense of intellectual autonomy from the British authorities, one that encouraged a break from classical orthodoxy and the construction of a distinctly native laissez-faire political economy.

Ricardo was born in London in 1772. The third of seventeen children, at fourteen he joined his father on the London Stock Exchange. Shortly thereafter, Ricardo renounced his Jewish faith to marry a Quaker. In the process he was estranged from his family. Ricardo began his own brokerage business, made a fortune, and retired at age forty-two to become a country

\footnotetext{
${ }^{49}$ Thomas Dew, Review of the Debate in the Virginia Legislature, 1831 and 1832 (Westport, CT, 1979), p. 53.

${ }^{50}$ For analysis of the American reception of Ricardo, see Tuner's The Ricardian Rent Theory in Early American Economics.

51 Joseph Dorfman, "Henry Vethake: Jacksonian Ricardian,” Joseph Dorfman and Rex G. Tugwell, Early American Policy: Six Columbia Contributors (Plainview, 1972), p. 155.
} 
gentlemen in Gloucestershire. In 1819 he became a member of the House of Commons representing Portarlington, Ireland, a seat he held until his death in 1823. By chance at age twenty-seven, Ricardo came across Smith's Wealth of Nations. This was his first exposure to the subject, and, in his own words, he "liked it so much as to acquire a taste for the study." ${ }^{2}$

Ricardo brought a new level of theoretical abstraction to nineteenth-century economic thought and he did more than any other economist to articulate classical orthodoxy. He wrote on a wide range of economic topics, but his theories on distribution-mainly rent, wages and profits-distinguished his writings. In his 1817 Principles of Political Economy and Taxation Ricardo defined rent as "that portion of the produce of the earth which is paid to the landlord for the use of the original and indestructible powers of the soil." ${ }^{153}$ Rent is paramount to Ricardo's analysis since it determines income distribution. When population expands greater sums of labor are required to cultivate less fertile lands. As it becomes more difficult to extract food from marginal lands the costs of labor, food, and rent increase. Over time labor competes for a smaller real wage and is forced to plow less fertile soils. "The fate of the laborer will be less happy," Ricardo wrote, "he will receive more money wages, it is true, but his corn wages will be reduced; and not only his command of corn, but his general condition will be deteriorated, by his finding it more difficult to maintain the market rate of wages above their natural rate," i.e., the Iron Law of Wages. $^{54}$

Labor is not the only sector disturbed by increased rents. Because labor's compensation is determined by a wages-fund, what the manufacturer pays in wages is subtracted from profits.

\footnotetext{
${ }^{52}$ Quote found in Henry Spiegel, The Growth of Economic Thought (Englewood Cliffs, NJ, 1971), p. 308. For discussion of Ricardo's Principles, see the editors' introduction in PierroSraffa and M.H. Dobbs, eds., The Works and Correspondences of David Ricardo (Indianapolis, 2005), vol. I; John Cunningham Wood, ed., David Ricardo: Critical Assessments (London, 1985); T.W. Hutchison, On Revolutions and Progress in Economic Knowledge (Cambridge, 1978), pp. 54-56; Gide and Rist, History of Economic Doctrines, pp. 139-160.

${ }^{53}$ David Ricardo, The Principles of Political Economy and Taxation (1817, London, 1992), p. 33.

${ }^{54}$ Ibid., p. 58.
} 
As food costs eat away at profits, manufacturers face declining returns. "Each man may, and probably will, have less absolute quantity; but as more laborers are employed in proportion to the whole produce retained by the farmer, the value of a greater proportion of the whole produce will be absorbed by wages, and consequently the value of a smaller proportion will be devoted to profits." 55 Tensions between rents and profits, combined with Malthusian overpopulation, keep labor at subsistence levels and diminish profits for manufacturers. Capital, Ricardo posited, "will diminish with every diminution of profit, and will cease altogether when their profits are so low as not to afford them adequate compensation for their trouble," i.e., the Law of Diminishing Returns. ${ }^{56}$ In the Ricardian system, capitalist and labor and the proprietors of land are at odds, precipitating social conflict. "The interest of the landlord is always opposed to that of the consumer and manufacturer. ${ }^{, 57}$ Ricardo's version of the natural order confined commercial society to the same rules that command the behavior of plants and animals. ${ }^{58}$ Market forces are comparable to scientific formulas that are ungovernable, indiscriminate in their application, and "rendered permanent by the powers of laws of nature."

The American treatment of Ricardo was as varied and critical as the antebellum discussion on Malthus. There were a few staunch Ricardians, mainly Thomas Cooper, John McVickar, and Francis Wayland, who repeated with slight variations the teachings of the Englishman. Their adherence to Ricardo was not determined by the same type of sectional biases that influenced the American reception of Malthus. Protectionists, on the other hand, flatly rejected Ricardo. Protectionists envisioned a dynamic economy, one quite different from the

\footnotetext{
${ }^{55}$ Ibid.,p. 75.

${ }^{56}$ Ibid.,p. 73.

${ }^{57}$ Ibid., p. 225

${ }^{58}$ Margaret Schabas, The Natural Origins of Economics (Chicago, 2005), pp. 113-119, 124, 129-134.

${ }^{59}$ Ricardo, The Principles of Political Economy and Taxation, p. 75.
} 
static model presented by Ricardo. Americans were destined for prosperity, increasing returns, and had yet to settle the continent's most fertile lands. Neither was America home to a monopolist class of landlords, as Ricardo had observed in England. Moreover, capital, labor, and agriculture coexisted in perfect harmony. Finally, Ricardo's theory of distribution was a bridge to laissez-faire, a logic naturally at odds with protectionist ideology. ${ }^{60}$

The immediacy of industrial development in the North brought upon its free-trade political economists a special urgency to review Ricardo's work. More than any Northern economists Henry Vethake exhibited the sharpest appreciation of the Ricardian system. Born in 1790 in British Guyana, Vethake moved to the United States at an early age. He enjoyed a long and illustrious academic career, teaching a variety of subjects and serving in various capacities at a number of Northeastern institutions. These included Columbia, Queen's College (Rutgers), College of New Jersey (Princeton), Dickinson, University of the City of New York (New York University), and the University of Pennsylvania. A well-regarded intellectual in his own time, Vethake was awarded honorary degrees from the College of New Jersey and Columbia, edited an entire volume of Encyclopedia Americana, and was considered the first professor in America to teach students political economy. He died in 1866 as professor of Mathematics at Philadelphia's Polytechnic College. ${ }^{61}$

Vethake's 1838 Principles of Political Economy drew heavily from Ricardo. ${ }^{62}$ But his sensibility to American exceptionalism precluded Vethake from accepting the totality of

\footnotetext{
${ }^{60}$ Many of these ideas are elaborated in chapters 6 and 7. They are succinctly reviewed in Turner's chapter on Henry Carey. The Ricardian Rent Theory in Early American Economics, pp. 110-142.

${ }^{61}$ Turner, The Ricardian Rent Theory in Early American Economics, p. 67; Dorfman, "Henry Vethake: JacksonianRicardian," p. 155.

${ }^{62}$ Paul Conkin, Prophets of Prosperity: America's First Political Economists (Bloomington, IN, 1980),pp. 133-134.
} 
Ricardo's system. He was, according to John Turner, "not...limited by the orthodox teaching."63 Vethake echoed the underlying optimism that marked domestic intellectual culture. His optimism did not rely solely on a materialistic foundation, however. Like many of his colleagues teaching in the Northeast, Vethake was a devout man. His belief in a benevolent creator provided the spiritual inspiration for his economic optimism. The economic order, Vethake wrote, was governed by an "Author of nature...co-operating" with humanity to ensure that individuals enjoyed the greatest amount of happiness possible. ${ }^{64}$ An unwillingness to admit that God rewarded the pious worker and industrious capitalist with economic and social disorder convinced Vethake of a more positive economic future.

Religion was not the only factor that influenced Vethake's thought. His economic thought reflected the social and political context of the era. Vethake's academic posts in the Northeast brought him in proximity to the epicenters of American industrialization. There he discovered, contrary to Ricardo's England, capital and labor working in harmony, encouraging prosperity and social stability rather than poverty and social strife. The entrepreneurial ethos that characterized antebellum culture prevented Vethake from forecasting the class tensions explicit in Ricardo's work. A Jacksonian Democrat, his ideal was a middle-class society where laissez-faire benefitted those of an industrious spirit. Vethake was drawn to political economy in part because the discipline offered practical lessons to improve the condition of labor without having to resort to the politician's "superficial views of expediency."65 But Vethake also made clear that his political economy was not geared toward radicalizing labor. Contrary to labor militants that employed Ricardo's labor theory of value for revolutionary designs, Vethake's was geared

\footnotetext{
${ }^{63}$ Turner, The Ricardian Rent Theory in Early American Economics, p. 71.

${ }^{64}$ Henry Vethake, The Principles of Political Economy (1844; reprint, New York, 1971), pp. 230, 303.

${ }^{65}$ Ibid., pp. 283, 258, 225, 404.
} 
toward subtle reforms. ${ }^{66}$ He anticipated an alternative industrial course, one with increasing returns to manufactures that had the potential to soften labor's transition into the industrial age. ${ }^{67}$

Vethake's liking for moderation is obvious in his treatment of distribution. His theory of distribution was heavily influenced by a belief in American exceptionalism and a Jacksonian ideology of equal opportunity industrial capitalism. Vethake rejected Ricardo's three-tiered economic class structure, for "the same person may unite in himself the characters of landlord, of capitalist, and of laborer, or of any two of them." ${ }^{98}$ The opportunity for social mobility, and even more, the parity of land distribution in the antebellum economy drew Vethake further from Ricardo and closer to the traditions of American political economy. ${ }^{69}$

While Vethake adapted Ricardian principles to the burgeoning industrialism of the North-and in a context of Yankee piety, the Southern treatment of Ricardo was not as clearly tied to the region's institutional and cultural traditions. A few radical fire-eaters interpreted classical doctrine as evidence of an impending collapse of free-labor society, but the more objective, academic economists found little relevance in Ricardo's writings to conditions in America. ${ }^{70}$ Like most Americans, the Southerners were not categorically committed to the

\footnotetext{
${ }^{66}$ A sect of neo-Ricardians/Ricardian Socialists emerged in Britain during the 1820s and 1830s. They employed the labor theory of value to attack industrialization. Noel Thompson, The People's Science: The Political Economy of Exploitation and Crisis 1816-1834 (Cambridge, 1984); Esther Lowenthal, The Ricardian Socialists (New York, 1924); George Stigler, "Ricardo and the 93\% Labor Theory of Value," The American Economic Review (June, 1958).

${ }^{67}$ Turner, The Ricardian Rent Theory in Early American Economics, p. 72.

${ }^{68}$ Vethake, Principles of Political Economy, p. 73. Vethake was, however, conscious of the struggles between labor and capital over income. Principles of Political Economy, p. 51.

${ }^{69}$ Conkin, Prophets of Prosperity, p. 126; Joseph Dorfman, The Economic Mind of American Civilization, 1606-1865 (New York, 1946), vol. II, p. 37.

${ }^{70}$ Lacy Ford, The Origins of Southern Radicalism: The South Carolina Upcountry (New York, 1988); Wilfred Carsel, “The Slaveholders' Indictment of Northern Wage Slavery," The Journal of Southern History (November, 1940); Jonathan Glickstein, Concepts of Free Labor in Antebellum America (New Haven, CT, 1991);Eric Foner, Free Soil, Free Labor, Free Men: The Ideology of the Republican Party Before the Civil War (Oxford, 1995); William Jenkins, Pro-Slavery Thought in the Old South (Gloucester,
} 
classical paradigm. Jacob Cardozo illustrates this point. He provided the South's most learned and critical review of Ricardo.

Like Ricardo, Cardozo was of Sephardic Jewish heritage. He was born in Savannah, Georgia in 1786, but he spent most of his life in Charleston. There he published the free-trade organ The Southern Patriot. ${ }^{71}$ He ran the paper until his death in 1873. As a journalist, according to one biographer, he exercised tremendous influence on public opinion and he "reveals Southern intellectual thought at its highest level.",72

Cardozo's 1826 Notes on Political Economy was written largely in reaction to the growing trans-Atlantic Ricardian consensus. ${ }^{73}$ "We are...convinced that if the principles of this theory," Cardozo wrote of Ricardian orthodoxy, "should be adopted as texts for lectures in our Colleges and Universities, it will greatly retard the progress of this important science among us. ${ }^{74}$ He challenged the two most fundamental precepts of the Ricardian paradigm. First, Cardozo rejected the labor theory of value. He argued that intellectual conventions and European conditions gave the labor theory of value its authority in nineteenth-century political economy. In European societies where land was becoming increasingly less productive, economists overstated labor's importance in wealth creation. The determinant of value was, according to Cardozo, never absolute; rather it was decided by a myriad of factors. ${ }^{75}$

VA, 1960); Shore, Southern Capitalists: The Ideological Leadership of an Elite, 1832-1885. See chapter 5 below.

${ }^{71}$ Barnett Elzas, The Jews of South Carolina: From the Earliest Times to the Present Day (Philadelphia, 1905), p. 177.

${ }^{72}$ Melvin Leiman, Jacob Cardozo: Economic Thought in the Antebellum South (Columbia, 1966),pp. 73$87,27-28$.

${ }^{73}$ Dorfman, The Economic Mind of American Civilization, vol. II, p. 558; Abram Flora, "Economic Thought in South Carolina, 1820-60,” (Ph.D. diss., University of North Carolina, 1957), p. 12.

${ }^{74}$ Jacob Cardozo, Notes on Political Economy (Charleston, 1826), p. iii.

${ }^{75}$ Ibid., pp. 66-70. 
Second, Cardozo attacked Ricardian rent. He was far more optimistic than the

Englishman. "What evidence is there, that skill, science and ingenuity are not, in all stages in the progress of society, able to overcome the natural inferiority of the soil which refuses to yield, without the co-operation of these powerful human aids, an increase of the means of subsistence." ${ }^{, 76}$ Cardozo also attacked Ricardo for integrating into his rent theory a Physiocratic bias that exaggerated the importance of land and agriculture. ${ }^{77}$ "The larger portion of the produce of the soil transferred, in the form of rent, in consequence of the social arrangements that have taken effect throughout Europe, has given rise to the idea of a net surplus that is peculiar to Agriculture.” This prejudice reflected an implicit social value common to European societies where land was monopolized by an aristocratic regime. "But...where more natural arrangements prevail, there is no surplus for rent, in the sense of this term as it is generally understood." ${ }^{, 78}$ Cardozo's criticisms of Ricardian rent were expanded to cover more generally the methodology by which political economists conducted the science. He emphasized the role of historical circumstances in economic analysis, understood political economy as culturally specific, and he rebuked Ricardo's claims of universality. Cardozo drew on American conditions for evidence to disprove Ricardo's so-called natural economic laws. He was one of the only free traders in the antebellum period to explicitly call for an absolute American divorce from European models. The British authorities, Cardozo discovered, had formulated economic principles without considering American conditions. Cardozo advocated for the construction of a distinctly American political economy. The nascent science, Cardozo wrote, could be more properly investigated here than in Europe since American "institutions and laws have done less to

\footnotetext{
${ }^{76}$ Ibid., p. 36.

77 Ibid.,p. 8. For analysis of Cardozo's theory of rent see Turner, The Ricardian Rent Theory in Early American Economics, p. 78; Allen Kaufman, Capitalism, Slavery, and Republican Values: Antebellum Political Economists, 1819-1848 (Austin, TX, 1982), pp. 127-129.

${ }^{78}$ Cardozo, Notes on Political Economy, p. 38.
} 
derange the natural order of things than where a vicious social organization has resulted either from military violence or a selfish policy."79

The political economy of Vethake and Cardozo exemplified the American reception of Ricardo. The Americans were not passive recipients of classical doctrine. Ricardo was not, contrary to the historian Paul Conkin, "domesticated." Neither did the Americans attempt, as Conkin claims, to "amend and revise" Ricardo's system "in ways that only illustrated how much they remained within the same analytical tradition." 80 The Americans operated on an alternative paradigm. Vethake's theological doctrine was simply more optimistic than Ricardo, and Cardozo initiated his economic analysis from a radically different set of precepts.

In the process of refuting Malthus and Ricardo, the Americans forged a new brand of laissez-faire, one that paid special consideration to domestic conditions. The failure to fall in line with the Malthusian/Ricardian paradigm does not exclude the antebellum economists from the trans-Atlantic free-trade movement. Rather it illustrates the lack of consensus within that movement. ${ }^{81}$ The tent under which liberal thinkers found shelter was broader and more complex than traditionally believed, welcoming a plurality of personalities whose understanding of the laissez-faire ideal varied considerably. In the antebellum discourse it was perfectly acceptable to be anti-Malthusian, anti-Ricardian, and yet still be labeled a free trader. The treatment of Malthus and Ricardo in the domestic laissez-faire discourse is also indicative of how many antebellum free traders did not take seriously the perils the British economists had linked to industrialization. Overpopulation, class warfare, and other dangerous features of free-market industrialization were attributed to the aristocratic qualities of British political and social systems. These dangers were neutralized by the exceptionality of American circumstances.

\footnotetext{
${ }^{79}$ Ibid., p. iii.

${ }^{80}$ Conkin, Prophets of Prosperity, p. 111.

${ }^{81}$ Hutchison, On Revolutions and Progress in Economic Knowledge, pp. 54-58, 77-79, 90.
} 
As the following chapter will show, however, the belief in American exceptionalism was not shared by all. The forecasts of Malthus and Ricardo were taken seriously by minority sects. These groups rejected contemporary notions of American exceptionalism, rebuked bourgeois values, rejected Malthus and Ricardo, and decisively broke from the American versions of laissez-faire economics. Although divide by regional lines, they expressed an affinity of ideas that provides a rather intriguing expression of the intellectual course of American economic thought. In the South, George Fitzhugh and George Frederick Holmes struck at Smith, Malthus, Ricardo and all that was sacred to free-trade ideology. In the North, the Jacksonian-era race toward industrialization cultivated the philosophical origins of American socialist thought. Combined, the Southern reactionaries and Northern laborites formed something of an intellectual alliance, encouraging a radically alternative social, political, and economic system, and providing antebellum American with its most definitive theoretical challenge to the free-market paradigm. 


\section{Chapter V}

The Crisis of Free Society: The Southern and Northern Reactionaries

By the mid-nineteenth century American economic thinkers paid increasing attention to the social externalities of industrial capitalism. In the North, a small but vocal group of labor advocates demanded profound alterations to the industrial economy. They appealed to segments of society outside of academia and government, mostly urban workers frustrated by market economies. The Northern laborites exemplified antebellum working-class mentality and they made important contributions to an organic, domestic version of early socialist thought. Langton Byllesby and Thomas Skidmore were the foremost representatives of this group. They found something akin to an intellectual alliance with Southern pro-slavery theorists, such as George Fitzhugh and George Frederick Holmes, who offered broad denunciations of bourgeois institutions. The philosophical inconsistencies of British classicism, the degradation of labor in industrial society, the callousness of market competition, and the emerging class stratification in the North serviced pro-slavery attacks on the free-labor regime. Both the Northern laborites and Southern pro-slavery writers struck at the core of classical/free-trade orthodoxy.

This chapter examines antebellum economic thinkers who articulated the sharpest rebuke of the free-trade model. The Northern laborites and pro-slavery reactionaries further indicate the lack of a laissez-faire consensus in the domestic discourse. The expansion of industry and the political conflict surrounding slavery provoked passionate challenges to the intellectual authority of laissez-faire. As the Civil War approached, the anti-market literature, particularly in the South, grew more hostile to social and political institutions associated with laissez-faire. The Northern laborites and pro-slavery reactionaries were not intellectual outliers either; they represented an essential element in the American discourse. 
The sectional divide in American politics exacerbated the divisions in American political economy. Southerners grew increasingly unreceptive of laissez-faire industrial ideology.

Southern free-traders expressed latent hostility toward industrialization, but the criticisms by Southern free-traders like Calhoun and Cooper were moderate, almost affable censures when compared to the militant denunciations of Fitzhugh and Holmes. The radical pro-slavery authors of the 1850s offered the period's most profound rejection of laissez-faire ideology. British classicism, industrialization, and all attendant bourgeois institutions were condemned for their lack of morality and abandoned as a mode of thought and policy. American industrialization, these critics insisted, engendered social, moral, and psychological transformations that Southern gentlemen found culturally distasteful, ethically offensive and socially hazardous. In their proslavery literature, Northern 'wage slavery' subjected white operatives to ceaseless drudgery based on the exploitation of man by man. Northern labor subsisted under conditions even worse than chattel slaves. Pro-slavery thinkers dismissed claims of American exceptionalism and argued that white American labor would be reduced to paupers. They returned, effectively, to the forecasts of Malthus and Ricardo. ${ }^{1}$

To Fitzhugh and Holmes fell the task of articulating pro-slavery ideology in its most essential form. Their writings hardly constituted a well-honed scientific study, but this should not discount their significance. Pro-slavery anti-free-trade thought wielded powerful influence in the South. "You, [Henry] Hughes, and I," Fitzhugh reported to Holmes, "have revolutionized public

\footnotetext{
${ }^{1}$ Jonathan Glickstein, American Exceptionalism, American Anxiety: Wages, Competition, and Degraded Labor in the Antebellum United States (Charlottesville, VA, 2002), pp. 20-26, 38-44; Jonathan Glickstein, Concepts of Free Labor in Antebellum America (New Haven, CT, 1991), pp. 142-159;Eric Foner, Free Soil, Free Labor, Free Men: The Ideology of the Republican Party Before the Civil War (Oxford, 1995), pp. xxvii-xiv; William Jenkins, Pro-Slavery Thought in the Old South (Gloucester, VA, 1960),pp. 298; Laurence Shore, Southern Capitalists: The Ideological Leadership of an Elite, 1832-1885 (Chapel Hill, NC, 1986),p. 17; James Huston, The Panic of 1857 and the Civil War (Baton Rouge, LA, 1987), pp. 99100; Eugene Genovese, The Slaveholder's Dilemma: Freedom and Progress in Southern Conservative Thought, 1820-1860 (Columbia, SC, 1992), pp. 6, 35-37, 56-57; Lacy Ford, The Origins of Southern Radicalism: The South Carolina Upcountry (New York, 1988), pp. 353-362; Wilfred Carsel, "The Slaveholders' Indictment of Northern Wage Slavery," The Journal of Southern History (November, 1940).
} 
opinion at the South on the subject of slavery."2 Their Southern contemporaries took them seriously. "My friends tell me that I lead the Southern mind," Fitzhugh wrote President James Buchanan in $1858 .^{3}$ Although Fitzhugh was prone to exaggeration, he and Holmes were indeed at the fore of pro-slavery philosophy.

Fitzhugh was born in 1806 near Brentsville, Virginia. He received little beyond a common education, rarely traveled, and spent much of his time reading from his personal collection of books and pamphlets. Before the Civil War Fitzhugh held minor government posts in the Attorney General's office and during the conflict he worked with the Southern Treasury. In the Reconstruction era he served alongside an ex-slave as an associate judge in the Freedmen's Bureau. He later moved to Kentucky, and then Texas where he died in 1881. In the pre-war era Fitzhugh's ideas circulated widely in articles written for De Bow's Review and in his two main works published in the 1850s, Sociology for the South and Cannibals All!. ${ }^{4}$

Fitzhugh's critique of laissez-faire political economy was the platform from which he developed the foundational principles of Southern plantation ideology. "He stripped away many of the contradictions and hesitations and brought those assumptions into the open," one historian wrote, "he took a major step toward the formation of a coherent slaveholders' world view."5 Fitzhugh's attack on laissez-faire economics offered a sweeping censure of bourgeois society. He provided the theoretical superstructure for the most radical and confrontational elements within

\footnotetext{
${ }^{2}$ Quote found in Eugene Genovese, The World the Slaveholders Made: Two Essays in Interpretation (New York, 1969), p. 130.

${ }^{3}$ Quote found in Joseph Dorfman, The Economic Mind in American Civilization, 1606-1865 (New York, 1946), vol. II, p. 933.

${ }^{4}$ Cannibals All! was reported to have "aroused the ire of Lincoln more than most pro-slavery books." Quote found in "George Fitzhugh, Sui Generis," C. Van Woodward's introduction to George Fitzhugh, Cannibals All!, or Slaves Without Masters (1857; reprint, Cambridge, MA, 1988), p. xxx.

${ }^{5}$ Genovese, The World the Slaveholders Made, p. 129.
} 
the pro-slavery movement. In the process, Fitzhugh assailed not only the Northern free-trade regime, but the entire edifice on which liberal America stood.

First, Fitzhugh struck at the liberal assumption of the "Right of Private Judgment," or the right to personal intellectual sovereignty and the right to act on that judgment. For Fitzhugh, the right of private judgment was the glue that held together the liberal ideological matrix. ${ }^{6} \mathrm{He}$ blamed the "enthusiastic speculative philosopher" Thomas Jefferson for disseminating values that were both socially and morally dangerous. There were natural and universal rights, Fitzhugh argued, chief among these was the right "to be taken care of and protected, to have guardians, trustees, husbands, or masters; in other words, they have a natural and inalienable right to be slaves."7 He mocked personal sovereignty and self-reliance as impractical ideals. Indeed, Fitzhugh estimated that nineteen out of twenty individuals were incapable of self-care. The one in twenty was fitted for authority, the others for slavery. "The weak in mind or body require guidance, support and protection," and it is the obligation of society's leaders to afford them protection. ${ }^{8}$ The protection of the weak was for Fitzhugh what constituted the sacred moral tenet in conservative government. "Instead of relaxing more and more the bounds that bind man to man, you must screw them up more closely," Fitzhugh demanded, "that, instead of no government, you must have more government."

The significance of Fitzhugh in the antebellum economic discourse lies in the extent to which he inverted the logic of laissez-faire ideology. He carried the rudimentary axioms of laissez-faire to their logical conclusion, illustrated their theoretical inconsistencies, and accomplished what he considered was the overthrow of the entire system of free-trade political

\footnotetext{
${ }^{6}$ Fitzhugh, Cannibals All!, pp. 132-133.

${ }^{7}$ Ibid.,p. 69.

${ }^{8}$ George Fitzhugh, Sociology for the South, or the Failure of Free Society (1854; reprint, New York, 1965), p. 178.

${ }^{9}$ Fitzhugh, Cannibals All!, pp. 253-254.
} 
economy. Although Fitzhugh dubbed Smith "absent, secluded, and unobservant," he did share with the Scotsman deep skepticism in the human intellect. ${ }^{10}$ While Smith's reservations were buried in his moral philosophy and generally raised only in discussions on mercantilist policymakers, Fitzhugh gave explicit and exaggerated expressions of skepticism that went beyond heads of state to ordinary individuals. Ministers and monarchs were badly mistaken in their understanding of the economy, but so too, Fitzhugh argued, were the hewers of wood and drawers of water. The common man was incapable of rationally calculating an enlightened self-interest. "Nature has made them slaves," Fitzhugh wrote, "to protect men, not merely from wrong and injustice from others, but from the consequences of their own vices, imprudence and improvidence."

Showcasing the internal inconsistencies of laissez-faire ideology was one of Fitzhugh's main pursuits, but he also took special pride in supplying a litany of inflammatory moral declamations on the socially abusive features of free-market society. In the decade preceding the Civil War, he participated in an increasingly aggressive campaign against the free-labor system. Slavery advocates argued that the Northern industrial regime was morally bankrupt. Fitzhugh's target was again Smith. The Wealth of Nations, which Fitzhugh judged the most influential book since the Bible, substituted for Christian piety a struggle for survival where the cunning exploit the obtuse. "A beautiful system of ethics this," Fitzhugh noted sarcastically, "that places all mankind in antagonistic positions, and puts all society at war."12 The danger of Smith's teachings, according to Fitzhugh, is its recommendations for both an economic and moral system. "The morality...is one of simple and unadulterated selfishness," Fitzhugh complained. "The

\footnotetext{
${ }^{10}$ Fitzhugh, Sociology for the South, p. 10.

${ }^{11}$ Ibid. ,p. 178; George Fitzhugh, "What Shall be Done with the Free Negroes" (1850), Sociology for the South, p. 265.

${ }^{12}$ Fitzhugh, Sociology for the South, p. 23.
} 
public good, the welfare of society, the prosperity of one's neighbors, is, according to them, best promoted by each man's looking solely to the advancement of his own pecuniary interests."13

Fitzhugh's writings helped introduce in the antebellum discourse sociological and psychological approaches to understanding the transformations wrought by industrial capitalism. His Sociology for the South was the first American treatise having in its title the term 'sociology.' The subtle, underlying cultural factors that constituted the relations between industrial capital and labor elicited Fitzhugh's attention. His description of labor's condition in some ways anticipated Marx and it drew strong parallels to antebellum Northern labor literature. ${ }^{14}$ Labor's woes evidenced the debased moral character of free-market regimes. Fitzhugh found industrial labor in a miserable state, locked in satanic mills toiling without end, living hand to mouth, and susceptible to the abuses of capital. "We do not know whether free laborers ever sleep. They are fools to do so; for, whilst they sleep, the wily and watchful capitalist is devising means to ensnare and exploit them." Capital stalks labor, into "every recess of domestic life, infects its food, its clothing, its drink, its very atmosphere, and pursues the hireling, from the hovel to the poorhouse, the prison and the grave. Do what he will, go where he will, capital pursues and persecutes him." ${ }^{, 15}$ Capital's exploitation of labor is driven by greed, is methodical, organized, and efficient, with booty taking the shape of profits won from a "moral Cannibalism" that free society celebrated as the gentleman's reward.

In the antebellum economic literature Fitzhugh was the most unequivocal in rejecting free-market society as an economic model for the South. Writing in the 1850s, Fitzhugh and most of the Southern intelligencia looked to European rebellions of the 1840s as the North's

\footnotetext{
${ }^{13}$ Ibid., p. 20.

${ }^{14}$ Genovese, The World the Slaveholders Made, pp. 168, 184-190; John Ashworth, Slavery, Capitalism, and Politics in the Antebellum Republic, Volume I: Commerce and Compromise, 1820-1850 (Cambridge, 1995), pp. 230, 232.

${ }^{15}$ Fitzhugh, Cannibals All!, pp. 202-203, 18, 16.
} 
future. Free labor, Fitzhugh wrote, is growing more cognizant of "their own numbers and strength," so that "all the reasoning in the world will not satisfy them that they who produce every thing should starve, in order that a handful of lords and capitalists should live in wanton waste and idle luxury."16 Although equality and liberty were promised to bring unprecedented benefit to the masses, it was precisely this segment of society that suffered under free-market regimes. "The little experiment of universal liberty that has been tried for a little while in a little corner of Europe, has resulted in disastrous and appalling failure."17

As the Civil War approached, radical Southerners like Fitzhugh amplified their warnings of social revolution in the industrialized world. The specter of labor insurrection helped buttress Southern claims that slavery was the most effective form of social organization. In Britain, free markets drove wages to subsistence levels. In Ireland, John Bull starved Irish peasants. In France, the people enjoyed liberté, égalité, fraternité, but lacked bread. And in the American North, labor was without a "home of his own; he is insecure of employment; sickness may overtake him at any time and deprive him of the means of support; old age is certain to overtake him, if he lives, and generally finds him without the means of subsistence; his family is probably increasing in numbers, and is helpless and burdensome to him." ${ }^{\text {"18 }}$ Liberty and equality, what Fitzhugh called "new things under the sun," had given license to the rich to oppress the poor. ${ }^{19}$

Fitzhugh's critique of industrialization drew the Southerner into an awkward intellectual alliance with trans-Atlantic socialism. "We, too, are a Socialist," Fitzhugh declared. ${ }^{20}$ The affinity Fitzhugh and other pro-slavery writers of the 1850s entertained for socialism is one of the

\footnotetext{
${ }^{16}$ Ibid., p. 76.

${ }^{17}$ Fitzhugh, Sociology for the South, pp. 70-71.

${ }^{18}$ Ibid., p. 38.

${ }^{19}$ George Fitzhugh, "Slavery Justified" (1849), Sociology for the South, p. 226.

${ }^{20}$ Fitzhugh, Cannibals All!, p. 23.
} 
peculiar features of antebellum economic thought. ${ }^{21}$ Fitzhugh, Marx and other socialists expressed sharp opposition to industrial capitalism at almost exactly the same time. The lines separating European and domestic socialists from conservative reactionaries in the plantation South often blurred. Fitzhugh's Tory-like disparagement of laissez-faire was influenced more by Carlyle than Marx, but it indicated the extent to which the pro-slavery theorist was willing to stretch his logic to defend Southern institutions, as well as the intellectual elasticity of the antebellum conservative-reactionary mind. Fitzhugh's attraction to socialism was, however, mainly for rhetorical purposes. "I never read a socialist author treating his subject philosophically in my life," he wrote in $1855 .{ }^{22}$ Social unrest, precisely the type advocated by socialists, was for Fitzhugh and other like-minded pro-slavery agitators a perilous evil. He was after all an agent of the planter elite who read with horror reports on the European revolutions of the $1840 \mathrm{~s}^{23}$

Fitzhugh penned most of his writings after the uprisings of 1848. Part of his defense of slavery rested on its ability to cultivate harmonious relations between masters and slaves. The "benign and protective institution" promoted a mutuality of interest between labor and capital. Slavery "begets domestic affection on the one side, and loyalty and respect on the other." ${ }^{24}$ Only under slavery were the masses, blacks and whites, guaranteed security and happiness. The institution sheltered labor in sickness, and in infancy and old age. Slavery provided a caring, paternal master compelled by moral and social norms to protect the weak and poor. "We tell those who ask for or require protection and support that 'they must submit to be controlled, for

\footnotetext{
${ }^{21}$ John Ashworth, Slavery, Capitalism, and Politics in the Antebellum Republic, p. 230.

${ }^{22}$ Quote found in Dorfman, The Economic Mind in American Civilization, vol. II, p. 929.

${ }^{23}$ Ashworth, Slavery, Capitalism, and Politics in the Antebellum Republic, p. 231.

${ }^{24}$ Fitzhugh, Cannibals All!, p. 201; Fitzhugh, Sociology for the South, p. 43.
} 
that price of security has ever been, and will be, the loss of liberty." 25 The master will defend his slave, Fitzhugh wrote, as he would any of his personal possessions. "A man loves not only his horses and his cattle, which are useful to him, but he loves his dog, which is of no use. He loves them because they are his." Such was the omnipotent design of Providence, Fitzhugh discovered, to make "the selfishness of man's nature the protecting aegis to shield and defend wife and child, slaves and even dumb animals."26

In the antebellum economic discourse Fitzhugh's writings encapsulated the philosophy of the American planter reactionary. He took pro-slavery ideology to its furthest conclusions. The pro-slavery voice grew more belligerent as the period came to a close. Driven by political pressures, Southerners like Fitzhugh employed an increasingly boisterous tone in their attacks on laissez-faire ideology. By 1860 the rift between North and South was as palpable in the period's economic discourse as it was in politics. Fitzhugh's attacks on industrial capitalism rattled American bourgeois culture and the aggressive character of his writings presumably helped field an army in defense of planter institutions.

In the post-war period Fitzhugh wrote articles for De Bow's Review, predicting the spread of "Yankee isms" in the North. "We have little hope for the future," Fitzhugh lamented, "the American Republic is near its end." The nation's only hope rested in a "conservative reaction....effected by the untrammeled aid of the South."27 Although a radical voice in the eyes of twenty-first-century historians, Fitzhugh was not an outlier. In the 1850 s scores of pro-slavery 'fire-eaters' challenged the emerging industrial-capitalist regime. ${ }^{28}$ The most systematic and learned analysis of this group came from George Frederick Holmes.

\footnotetext{
${ }^{25}$ Fitzhugh, Cannibals All!, p. 94.

${ }^{26}$ Fitzhugh, Sociology for the South, p. 46.

${ }^{27}$ George Fitzhugh, "The Impending Fate of the Country," De Bow's Southern and Western Review (December, 1866), pp. 567-569.
} 
Holmes was born in 1820 in British Guiana and educated in England before arriving in America at age eighteen. At age twenty-eight he ascended to the presidency of the University of Mississippi. He was by then widely recognized as an authority in social and political thought.

His time at Mississippi was brief, however. Much of the remainder of his career was spent at the University of Virginia where he taught for 40 years until his death in $1897 .^{29}$

In countless articles published in the South's most influential journals, Holmes presented the most mature Southern refutation of laissez-faire in the antebellum discourse. Holmes' criticisms were more profound than Fitzhugh's. He was not, however, as Eugene Genovese called him, "an overrated pedant." communicate analyses of Northern bourgeois society in scholarly assessments. This imbued Holmes' writings with an element of objectivity that was missing from the propagandist style of other Southern fire-eaters like Fitzhugh. Holmes stood closer to the planter-cavalier model than any other Southern thinker. He desired a social order absent of market values and he rejected unequivocally the fundamental principles of free-market industrial capitalism.

Holmes' critique of bourgeois ideology assumed several forms. He was especially interested in the social developments attendant to the emergence of large-scale industry. But Holmes also paid special notice to the development of laissez-faire as an intellectual movement. Free-trade political economy, Holmes argued, lacked the basic standards by which methodical

\footnotetext{
${ }^{28}$ Radical pro-slavery thought is discussed in Eric Walther's The Fire-Eaters (Baton Rouge: Louisiana State University Press, 1992); Ashworth, Slavery, Capitalism, and Politics in the Antebellum Republic, pp. 216-228; Paul Finckleman, ed., Defending Slavery: Proslavery Thought in the Old South (Boston, 2003); Jenkins, Pro-Slavery Thought in the Old South. Several works are representative of Southern radical ideology. The key figures are Henry Hughes, Treatise on Sociology, Theoretical and Practical (1854; reprint, New York, 1968); Edmund Ruffin, The Political Economy of Slavery, or, The Institution Considered in Regard to Its Influence on Public Wealth and the General Welfare (1853), Paul Finckleman, ed., Defending Slavery: Proslavery Thought in the Old South (Boston, 2003); and the writings and speeches James Henry Hammond, Nathaniel Beverly Tucker, Robert Rhett, and William Yancey.

${ }^{29}$ Neal Gillespie, The Collapse of Orthodoxy: The Intellectual Ordeal of George Frederick Holmes (Charlottesville, VA, 1972); Dorfman, The Economic Mind of American Civilization, vol. II, p. 920

${ }^{30}$ Genovese, The World the Slaveholders Made, p. 130.
} 
inquiry is customarily handled and could therefore make no claims to scientific objectivity. Even the most central concepts-capital, labor, and value-lacked precise definition. "The obscurity and fluctuation of their terms arise from the previous want of lucidity in their conceptions, and they generate in the progress of speculation further obscurities and fluctuations, and very frequently fallacies which are neither discerned nor suspected." Holmes contended that political economy could not reach definitive conclusions, "the house is built upon sand," he declared. ${ }^{31}$

Challenging the theoretical basis of laissez-faire was a technique that pro-slavery writers used to undermine the Northern free-labor regime. Free-trade ideology, according to Holmes, was symbolic of the degenerated nineteenth-century liberal mind. Like most antebellum Southerners Holmes was suspicious of liberal intellectual culture. The South grew less and less tolerable of Enlightenment ideas. ${ }^{32}$ This anti-intellectual disposition resonated in Southern economic thought. "We are, indeed," Holmes declared in the Southern Quarterly Review, "no great believers in 'the march of the intellect,' in the nineteenth century." 33 Laissez-faire political economy was the most conspicuous and harmful philosophical fiasco of the era, Holmes insisted. Indeed, Smith, Ricardo and Malthus were little more than charlatans clothed in learned dress, servants to the prevailing industrial order. Their treatises gave a false air of theoretical prestige to “the Gospel according to Mammon," helping legitimize the impetuous desires of humanity by

${ }^{31}$ George Frederick Holmes, “Capital and Labor," De Bow's Southern and Western Review (March, 1857), p. 256.

${ }^{32}$ W.J. Cash, The Mind of the South (New York, 1941); Clement Eaton, The Freedom of Thought Struggle in the Old South (New York, 1964); William Dodd, "The Social Philosophy of the Old South," The American Journal of Sociology (May, 1918); Robert Taylor, Cavalier and Yankee: The Old South and American National Character (New York, 1961); Richard Hofstadter, Anti-Intellectualism in American Life (New York, 1962).

${ }^{33}$ George Frederick Holmes, “Carlyle's Latter-Day Pamphlets," Southern Quarterly Review (November, 1850), p. 329. 
inventing an ideology marked by "the immediate gratification of the most important number-Number One." 34

Holmes also launched antebellum America's most systematic critique of the psychological consequences of free-markets. His writings indicate that the differences between the North and South in antebellum America were as much cultural and they were economic. In free-market societies, "individual life is swallowed up in....business avocations:-the lust of gold is the main-spring of....actions." ${ }^{35}$ The human spirit was transformed, according to Holmes, its mental faculties reconstructed as monetary scales. Moral conventions were determined not by tradition or ethic, but the ability to satisfy pecuniary wants. When material gain becomes the governing spirit of human existence, Holmes wrote, society "rapidly degenerates into a curse."36 The moral and spiritual necessities of the human race were disregarded, "ideas of obligation and duty have given place to gain and expediency:-immutable right and unchangeable wrong are measured and tested by the surplus or deficit of their aggregate money returns." Cast in the allengrossing chase for wealth, the individual has "overlooked everything else."

Like many pro-slavery critics of industrial society, Holmes appealed to Northern workers in his writings. Holmes highlighted the exploitative tendencies of industrial capitalism, strengthening the intellectual bond between socialists and the conservative planter elite. Although his analysis of free labor was geared toward elevating the moral position of slavery, unlike Fitzhugh, Holmes harbored a sincere affinity for socialist programs. "The first grand aim then of social amelioration," he wrote, "should be to establish a more thorough and equal

\footnotetext{
${ }^{34}$ Holmes, "Carlyle's Latter-Day Pamphlets," p. 354; George Frederick Holmes, "The Nineteenth Century," Southern Literary Messenger (August, 1851), p. 460.

${ }^{35}$ Holmes, "The Nineteenth Century," p. 461.

${ }^{36}$ George Frederick Holmes, “Failure of Free Societies," Southern Literary Messenger (March, 1855), p. 133.

${ }^{37}$ Holmes, "The Nineteenth Century," pp. 460, 465.
} 
distribution of the means of sustaining life-of productions-by a natural, healthful, and orderly modification of the laws of property." ${ }^{, 38}$ His interpretation of the historical development of labor was consistent with socialist thought. The transition from slave to feudal to free labor was initiated once capitalists realized the latter optimized profit. "The more it has been released from legal restrictions or deprived of legal protection," Holmes wrote of labor, "the worse has become the condition of the laborer, the more precarious his support, and the more stringent and crushing the pressure of the circumstances-that ever burning circle of fire-by which he is surrounded." The emancipation of serf and slave was prompted not by a pious, enlightened heart, but from capital recognizing new opportunities to exploit labor with scarcely any attendant responsibilities. "The principle which occasioned the substitution of free for slave labor was the prospect of diminished expenditure and increased gain...Look into their declamations, contemplate their tactics, survey the whole literature of political economy, and it will be manifest that the real argument is simply that free labor is cheaper and more productive or profitable than slave labor., 39

For Holmes, industrial capitalism was incompatible with conservative Southern culture. Even so the social and moral cannibalism inherent to industrial regimes undermined the interests of humanity. Southern reactionaries imagined themselves global crusaders charged with rescuing humanity from the perils of industrial capitalism. "It is to be feared that capital is applied most diligently to the procurement of a cheaper substitute for human labor, and to its exclusion. The steam man is the competitor of the human man. ${ }^{40}$ The freemarket employs the wonders of science and technology toward the manipulation of the masses. Laissez-faire political economy turned human exploitation into a technical science, soliciting the most efficient methods to profit

\footnotetext{
${ }^{38}$ George Frederick Holmes, “Greeley on Reforms,” Southern Literary Messenger (May, 1851), p. 263.

${ }^{39}$ Holmes, “Slavery and Freedom,” Southern Quarterly Review (April, 1856), pp. 81, 84.

${ }^{40}$ Holmes, “Carlyle's Latter-Day Pamphlets," p. 345
} 
at the expense of others. Echoing Malthusian pessimism, he prophesized if the industrial machine continued its then current pace, it will "reach speedily the limit when the masses, not of one country, but of the whole commercial world will be pauperized, and unable to keep up with the production... and enfeebled by disease so as to be unable to supply the physical force required for the creation of the raw material." 41

Holmes' critique of capitalist exploitation serviced pro-slavery claims that the North marched inevitably toward social revolution. Calhoun's prediction of worker unrest discussed in chapter 3 was a persistent line of argument employed by radical Southerners against free labor, and as the nation drew closer to Civil War, pro-slavery thinkers highlighted contemporary incidents of worker strife in the North and abroad. "The different classes are arrayed against each other," Holmes warned, "the rich dread and scorn the power of the masses...The multitudes envy, hate, and menace the wealth:-they threaten agrarianism or the less sweeping remedies of violence and fraud:-for they feel that inherent discrepancy has grown into bitter hostility and inexplicable wrong." ${ }^{42}$ Slavery was the obvious alternative. Nineteenth-century reports on the condition of free labor illustrated that the Southern slave was far better off than the factory operative. Holmes voiced the Southern maxim that slavery was a positive good; chiefly because the institution accomplished what no other economic system could. It brought the interests of capital and labor together. ${ }^{43}$

Pro-slavery reactionaries like Holmes and Fitzhugh engaged the free-market discourse to defend slavery, but they also took the opportunity to launch broader criticisms of political liberalism. In the antebellum literature lengthy expositions on political theory often accompanied

\footnotetext{
${ }^{41}$ George Frederick Holmes, "Speculation and Trade," Southern Quarterly Review (November, 1856), p. 23.

${ }^{42}$ Holmes, “The Nineteenth Century,” p. 461.

${ }^{43}$ George Frederick Holmes, "Review of Uncle Tom's Cabin," Eric McKirtrick, ed., Slavery Defended: The Views of the Old South (Englewood Cliffs, NJ, 1963), p. 106; Holmes, "Slavery and Freedom," pp. 71, 73, 86-88, 93; Holmes, "Greeley on Reforms," p. 260.
} 
economic inquiries. This was especially the case in the radical pro-slavery writings where political economy was part of a multi-layered attack on Northern institutions. Holmes and much of the conservative planter elite expressed deep hostility toward liberal political ideology. In the mind of the Southern reactionary, laissez-faire political economy and the doctrine of political individualism were intellectual siblings. "But the cry of the capitalists for the Laissez faire system," Holmes wrote, "in order that their acquisition of gains might be unrestricted, has led to the supposition that the entire absence of political restraints was the Utopia of political organization, and the surest evidence of Democratic principles." ${ }^{44}$ The tendency of nineteenthcentury theorists to unite into a single movement economic and political liberalism threatened social stability. Laissez-faire economics, Holmes argued, finds some truth "within the narrow range of their legitimate application; but when we see it wrenched from its just employment, as an explanation of the increase of wealth, into a cannon for the government of nations," it engendered social catastrophe. ${ }^{45}$

By the 1850 s radical pro-slavery authors were denouncing everything associated with Yankee culture. Like Fitzhugh, Holmes elaborated what other opponents of the liberal creed had only hinted at. "There is one great delusion of political economy, not as a science, but as a practical rule, that it conceives the world will steadily pursue what is best, not what seems best." ${ }^{26}$ For Holmes, laissez-faire and the doctrine of individual sovereignty left society open to chance. He also expressed radically anti-liberal views on private property. In this regard, Holmes illustrated the extent to which reactionary Southern economic thought was divorced from American liberal traditions. "The wants of society," Holmes wrote, "have outgrown received formulas; that the existing elements of social organization have in consequence been thrown into

\footnotetext{
${ }^{44}$ Holmes, "The Nineteenth Century," p. 466.

${ }^{45}$ Holmes, “Carlyle’s Latter-Day Pamphlets,” p. 328.

${ }^{46}$ Ibid., p. 351.
} 
fatal anarchy and discord." ${ }^{47}$ The social transformations wrought by political individualism and industrial capitalism required that nineteenth-century intellectuals rethink their most fundamental assumptions on the moral responsibilities of property ownership. Property was not sacred, Holmes concluded. "In all ages, the forms in which it [property] must be confined, have been a legitimate subject of legislative and constitutional enactment." 48

The economic writings of Holmes indicate that laissez-faire was not the dominant paradigm of the antebellum period. Holmes was not an anomaly in an otherwise laissez-faire American economic discourse either. Antebellum economic thought was inclusive of a wide range of conflicting ideological platforms. These differences were amplified as the nation came closer to the Civil War. This is not to say that the political economy of radicals like Holmes and Fitzhugh was compelled into existence by political imperatives. The radical pro-slavery literature contains ideas central to American conservative thought that predate the $1850 \mathrm{~s} .{ }^{49}$

The Civil War destroyed Holmes' vision of America. He interpreted the conflict as a "crusade of anarchy, corruption, and agrarianism." ${ }^{, 50}$ Holmes predicted the North was headed toward a military dictatorship. At Lincoln's death he forecast that the internal contradictions of Northern society would unleash "all the furies of agrarianism and anarchy." A1 After the war Holmes took the oath of amnesty and returned to teaching and writing at the University of Virginia. His obituary in the American Historical Review noted the professor had "published little, but was of note as a teacher." ${ }^{52}$ Despite Holmes' contributions to the social sciences after

\footnotetext{
${ }^{47}$ Holmes, "Greely on Reforms," p. 260.

${ }^{48}$ Holmes, "Carlyle’s Latter-Day Pamphlets,” p. 331

${ }^{49}$ Louis Hartz, The Liberal Tradition in America: An Interpretation of American Liberal Thought Since the Revolution (Chicago, 1968), pp. 197-200.

${ }^{50}$ Quote found in Gillespie, The Collapse of Orthodoxy, pp. 202-203.

${ }^{51}$ Quote found in Ibid., p. 210.
} 
the Civil War the anti-market thrust of his writings vanished during the Gilded Age and he was only recently rescued from historical oblivion. ${ }^{53}$

Holmes, Fitzhugh and the other radical pro-slavery writers who abhorred the doctrines of classical political economy represented important facets of the antebellum economic mind. "The reactionary enlightenment" of radical pro-slavery ideology was, as Louis Hartz wrote, "the great imaginative moment in American political thought." The ideology was not however, rejected or neglected as Hartz argues. ${ }^{54}$ Rather it was defeated by the superior numbers and resources of the North. And contrary to liberal consensus historiography, the radical pro-slavery writers were not aliens in an otherwise free-market intellectual environment. The North had its own cohort of critics that issued sharp rebukes of laissez-faire doctrine. Although the Northern radicals were often times abolitionists and prescribed reforms that were quite different from the pro-slavery authors, the two groups shared an explicit desire to reconstruct America along pre-market values. The Northern anti-market thinkers, like the Southern pro-slavery radicals, contributed important conceptual tools that challenged the fundamental principles of laissez-faire ideology.

The postponement of an American edition of Marx's Communist Manifesto until 1871 did not prevent circulation of socialist literature in America. European labor radicals that migrated to the United States after the revolutions of 1848 found in the industrial North a burgeoning working-class movement. In the 1820 s trade and craft associations organized two separate Working Men's Party, one in Philadelphia and the other in New York. The leadership consisted mainly of independent journeymen, but the party rank and file included artisans from a variety of industries, as well as dock workers, wage laborers, and even small merchants. They

\footnotetext{
${ }^{52}$ Quote found in The American Historical Review (January, 1898), p. 392.

${ }^{53}$ Gillespie's The Collapse of Orthodoxy is a major work in this effort.

${ }^{54}$ Hartz, The Liberal Tradition in America, p. 176.
} 
sponsored public education reform, the 10-hour day, the abolition of imprisonment for debt and the end of prison labor. ${ }^{55}$

Labor reformers in the 1820 s and 1830 s focused a great deal of energy on land reform.

Increasing rents and the concentration of land ownership that were central components to

Ricardo's analysis attracted American labor to land redistribution schemes. The early American agrarian movement worked largely in unison with the labor movement and often shared the same leadership. But the agrarians tended to advance reforms sympathetic to free-market ideology. Their chief accomplishment, the Homestead Act of 1862, was considered by advocates a fulfillment of the principles of 1776 and in the mode of a Jeffersonian middle-class ideology. ${ }^{56}$ Labor-intellectuals from the agrarian movement injected ideas into the debate that were entirely incompatible with bourgeois institutions. ${ }^{57}$ Chief among these was Langton Byllesby.

\footnotetext{
${ }^{55}$ Timothy Messer-Kruse, The Yankee International: Marxism and the American Reform Tradition, 18481876 (Chapel Hill, 1998). Historians have debated the existence of an anti-capitalist class conscious among antebellum American industrial labor. Sean Wilentz finds a "class-conscious, inter-ethnic New York labor movement of the mid-1830s," Chants Democratic: New York City and the Rise of the American Working Class, 1788-1850 (New York, 1984), p. 9. Wilentz's assessment is supported by Carl N. Degler, "The Locofocos: Urban 'Agrarians,' The Journal of Economic History (September, 1956); James Roger Sharp, The Jacksoniansversus the Banks: Politics in the States after the Panic of 1837 (New York, 1970); John McFaul, The Politics of Jacksonian Finance (Ithaca, NY, 1972); John Ashworth, 'Agrarians' and 'Aristocrats': Party Political Ideology in the United States, 1837-1846 (New York, 1987); Arthur Schlesinger, The Age of Jackson (Boston, 1946); Charles Sellers, The Market Revolution: Jacksonian America, 1815-1848 (New York, 1991); Jamie Bronstein, Land Reform and Working-Class Experience in Britain and the United States, 1800-1862 (Stanford, 1999). Edward Pessen describes the labor leaders as 'uncommon.' Most Uncommon Jacksonians: The Radical Leaders of the Early Labor Movement (New York, 1967). Joseph Dorfman and Walter Hugins argue the heterogeneity of the working class movement precluded the formation of a single ideological pattern and that in general the leaders of the movement were laissez-faire entrepreneurs. Joseph Dorfman, "The Jacksonian Wage-Earner Thesis," The American Historical Review (January, 1949); Walter Hugins, Jacksonian Democracy and the Working Class: A Study of the New York Workingmen's Movement, 1829-1837 (Stanford, 1960).

${ }^{56}$ Bronstein, Land Reform and Working-Class Experience; Mark Lause, Young America: Land, Labor and the Republican Community (Urbana, IL, 2005).

${ }^{57}$ Besides Byllesby and Skidmore, Stephen Simpson and John Pickering illustrate antebellum laboriteideology. Simpson, The Working Man's Manual: A New Theory of Political Economy, On the Principle of Production the Source of Wealth (Philadelphia, 1831); Pickering, The Working Man's Political Economy Founded upon the Principle of Immutable Justice, and the Inalienable Rights of Man; Designed for the Promotion of National Reform (1847, reprint, New York, 1971). Sean Wilentz'sChants Democratic is the most insightful work on the antebellum labor movement and antebellum labor ideology.
} 
Born in Philadelphia in 1789 Byllesby was just an infant when his parents died of cholera. ${ }^{58} \mathrm{He}$ served as an editor for a local newspaper in Western Pennsylvania before moving his family to New York City. There Byllesby worked as a journeyman proofreader for Harper Brothers. In 1826 Byllesby wrote Observations on the Sources and Effects of Unequal Wealth. The work, according to one historian, was "the first angry American economic treatise," initiating "a tradition of class-conscious economic advocacy by those who identified themselves with an American working class." ${ }^{, 59}$

Byllesby assumed the task of articulating the concerns of the disaffected journeyman mechanic. His political economy gave voice to a burgeoning working-class ideology. He did not, as some historians have claimed, advocate a moderate strain of agrarianism. ${ }^{60}$ Land redistribution was part of his program, but it was ancillary to a comprehensive reorganization of the urban, industrial economy. Byllesby's economic thought was set in an alternative paradigm from the classical model. Indeed, he sought the complete overthrow of the market economy, or in his words, "revision of the present system of the arts of life; and distribution of the products of labor."61

\footnotetext{
${ }^{58}$ Joseph Dorfman, "L. Byllesby and His Plan for Economic Reconstruction" provides a brief biographical sketch of Byllesby in an introductory essay to Observations on the Sources and Effects of Unequal Wealth with Propositions Towards Remedying the Disparity of Profit in Pursuing the Arts of Life and Establishing Security in Individual Prospects and Resources (1826; reprint, New York, 1961). Treatment of Byllesby can also be found in Paul Conkin, Prophets of Prosperity: America's First Political Economists (Bloomington, IN, 1980), pp. 234-246; Martin Burke, The Conundrum of Class: Public Discourse on the Social Order (Chicago, 1995), pp. 84-86; John Lauritz Larson, The Market Revolution in America: Liberty, Ambition, and the Eclipse of the Common Good (Cambridge, 2010), pp. 146-147; Wilentz, Chants Democratic, pp. 164-167; Dorfman, The Economic Mind in American Civilization, vol. II, pp. 638-641.

${ }^{59}$ Conkin, Prophets of Prosperity, p. 234.

${ }^{60}$ Conkin, Prophets of Prosperity, pp. 234-236, treats Byllesby under the chapter title "Agrarians." Joseph Dorfman, "L. Byllesby and His Plan for Economic Reconstruction," calls the Observations "the first systematic American treatise" on Owenism, p. 9.

${ }^{61}$ Byllesby, Observations on the Sources and Effects of Unequal Wealth, p. 23.
} 
Byllesby's work is as much a critique of industrial capitalism as it is a systematic inquiry in political economy. He was, however, familiar enough with the nineteenth-century economic discourse to structure his criticisms of laissez-faire on the very principles that serviced classical doctrine. He began his analysis with reaffirmations of the Ricardian labor theory of value. "Labor alone is the source of all wealth," Byllesby declared. ${ }^{62}$ But in the current free-market system "the products of labor belong to almost any other than the producer, who generally obtains from the application of his power no more than a bare subsistence."63 The sequestering of labor's wealth into the hands of a parasitic few forced the American worker into a condition comparable to the chattel slave. Moreover, it cemented the class stratification that marked America's industrial quarters.

Byllesby was one of the first Americans to attribute class hostilities to free markets. He anticipated Fitzhugh and Holmes by more than two decades. Byllesby emphasized the role of four free-market institutions that in his view were responsible for aggravating class relations and precipitating inequities in the distribution of wealth. He struck first at the banking industry. Byllesby anticipated Jackson's war on banks by declaring financial institutions the main culprits in effecting economic inequality. Financiers perpetuated an assembly of frauds on the working class. The moneyed interests combined with middle-men and merchants, or those engaged in what Byllesby called "trafficking," forcing labor to exchange its products for a fraction of their worth. ${ }^{64}$ Commerce, or the various stages separating labor from consumers was tantamount to theft since it failed to compensate workers with wages equal to the labor spent in the production process. Byllesby also challenged the ethical propriety of profits. All profit, he declared, was a morally depraved value exploited from labor. Finally, Byllesby predicted that machinery would

\footnotetext{
${ }^{62}$ Ibid., p. 52.

${ }^{63}$ Ibid., p. 30.

${ }^{64}$ Ibid., p. 53.
} 
hasten unemployment crises, reduce wages, weaken consumer purchasing power, and initiate general gluts. Thus, according to one historian, Byllesby was one of the first American political economists to investigate the effects of technology on unemployment and the distribution of wealth. $^{65}$

The reforms suggested by Byllesby would have abolished the market system. His plan for an "Association for Securing Equal (or Mutual) Advantages (or Interests)" designed a program of "equalization." "66 This included the organization of society into industrial communities in the form of joint-stock corporations. These labor associations harnessed the productive powers of industry, secured high employment, provided just reward for labor, and eliminated poverty. Labor should, Byllesby figured, when combined with industrial machinery, find four to five hours a day sufficient for the production of subsistence. Under the new regime trade would be based rightfully on the principle of reciprocity, all would have equal entitlement to the land, inheritance abolished, and interest prohibited.

Byllesby's economic system was not, as Joseph Dorfman has suggested, designed to defend the laissez-faire ideal. Neither was Byllesby simply protesting "against privilege and invidiousness. ${ }^{, 67}$ Dorfman's liberal/consensus reading of Byllesby-that the laborite incorporated "business promotion with socialist rhetoric" is based on the latter's spoof on the opponents of patents. ${ }^{68}$ Dorfman's assessment failed to recognize the seriousness of Byllesby's proposals. Neither does Dorfman provide adequate explanation for how the revolutionary reforms suggested by Byllesby could be reconciled with the free-market antebellum economic order.

\footnotetext{
${ }^{65}$ Bruce Laurie, Artisans into Workers: Labor in Nineteenth-Century America (New York, 1989), p. 65.

${ }^{66}$ Byllesby, Observations on the Sources and Effects of Unequal Wealth, pp. 110, 117.

${ }^{67}$ Dorfman, “The Jacksonian Wage-Earner Thesis,” p. 306.

${ }^{68}$ Dorfman, The Economic Mind of American Civilization, vol. II, p. 641.
} 
Like the Southern reactionaries, Byllesby's political economy was antithetical to the laissez-faire model. Unlike the Southern reactionaries, however, Byllesby was committed to a socialist agenda. He admitted an intellectual debt to the British neo-Ricardian/Ricardian Socialists, in particular the Scottish economist John Gray. The neo-Ricardians/Ricardian Socialists extrapolated principles from Ricardian political economy, mainly the labor theory of value, to undermine the logic of classical doctrine. The neo-Ricardians/Ricardian Socialists argued that since the value of commodities equaled the quantity of labor embodied in them, yet capitalists apportioned the lion's share of income through interest, rent, and profits, then labor's compensation was unjustly appropriated. Their ideas were developed during the first-half of the nineteenth century and eventually found a more acute exposition in the works of Marx. ${ }^{69} \mathrm{After}$ having read Gray, Byllesby found a clear "similarity of ideas" and rushed to include protracted quotations from Gray's Lecture on Human Happiness (1826) in his own Observations. ${ }^{70}$

Byllesby's work must be treated beyond the context of the Jacksonian war on monopoly and banks. Antebellum economists were deeply engaged in the trans-Atlantic discourse and often exchanged ideas with European thinkers. Byllesby's work is indicative of an antebellum working-class ideology growing increasingly hostile to free-markets. As one historian has noted, "with Byllesby...we witness the acceleration of a fundamental shift in language and sentiment...toward a recognition that a deeper matrix of exploitation and unequal exchange for labor was responsible for the plight of the mass...,"71

The socialist impulse behind Byllesby's thought also appeared in Thomas Skidmore's work. Son of Connecticut farmer, Skidmore spent his early adult years searching for work in the

\footnotetext{
${ }^{69}$ Noel Thompson, The People's Science: The Political Economy of Exploitation and Crisis 1816-1834 (Cambridge, 1984); Esther Lowenthal, The Ricardian Socialists (New York, 1924); George Stigler, "Ricardo and the 93\% Labor Theory of Value," The American Economic Review (June, 1958).

${ }^{70}$ Quote found in Wilentz, Chants Democratic, p. 164. For an examination of John Gray see Thompson, The People's Science; Lowenthal, TheRicardian Socialists.

${ }^{71}$ Wilentz, Chants Democratic, p. 167.
} 
Northeast. In 1819 he settled in New York City, educated himself with the works of Jefferson, Locke and Rousseau, and became active in local politics. Journalist, teacher, printer, carpenter, and listed as a "machinist" in the catalogues of New York's Working Men's Party, the otherwise obscure craftsman had by 1830 became the intellectual head of the antebellum labor movement. He died in 1832 of cholera at age forty-two.

Skidmore articulated the most mature expression of working-class antagonisms toward laissez-faire ideology. ${ }^{72}$ His criticisms were as incendiary as Fitzhugh's. In his 1829 The Rights of Man to Property! Skidmore proposed radical transformations to the antebellum economy. He scoffed at the notion of private property, attacked the foundational principles of classical doctrine, and aimed to reconstitute society along pre-bourgeois capitalist lines. Skidmore intended, in his own words, to "entirely remodel the political structure of our state, and make it essentially different from anything else.",73

Skidmore's criticisms of free-market institutions were developed into an economic doctrine entirely at odds with laissez-faire ideology. He advanced what he described as a political economy pursuant of rational ends, taking basic though radical economic assumptions to their furthest logical conclusions. According to one historian, Skidmore contributed to "something of a theoretical breakthrough" for antebellum working-class ideology. ${ }^{74}$ His first target was the labor theory of value. Although labor adds value to property, it does not imply property rights. "Why will not labor bestowed upon property in possession give title: Because the property itself, is another's, and before any labor can be honestly bestowed upon it, that other,

\footnotetext{
${ }^{72}$ For a sympathetic biography on Skidmore, see Amos Gilbert, A Sketch of the Life of Thomas Skidmore (1834; reprint, Chicago, 1984). Other analysis of Skidmore include Conkin, Prophets of Prosperity, pp. 237-239; Wilentz, Chants Democratic, pp. 182-187; Dorfman, The Economic Mind in American Civilization, vol. II, pp. 641-645; Wilentz, The Rise of American Democracy, p. 353.

${ }^{73}$ Thomas Skidmore, The Rights of Man to Property! (1829; reprint, New York, 1966), p. 8.

${ }^{74}$ Wilentz, Chants Democratic, p. 185.
} 
who alone owns its, must give his consent." abolition of private property. All men have equal claim to the earth's resources. "The soil," Skidmore declared, "belongs....equally....to all who are found upon it."76 Only through the community's consent can property rights exist. Property rights are not sacred. Rather they are entirely conventional. Moreover, the accumulation of property by one should never inhibit another's claim to subsistence, for this entailed a violation of the most basic human right. The latter incensed Skidmore and other laborites of the Jacksonian era. Under bourgeois property rights, he wrote, "a part, and that a very large part, of the human race, are doomed, of right, to the slavery of toil, while others are born only to enjoy.",77

The transformative effects of Skidmore's program separated his economic ideology from other laborites. Skidmore called for immediate working-class revolution. "Is it not time for the people," Skidmore asked, "those who have rights as well as the rich, to interpose on their behalf?" His measures were directed explicitly at the rich. "Let us look then upon the rich man, as he has been, or as he now is, among us, rather as a curse, than as a blessing, rather as a something, himself, which it is proper to exterminate... Nor let the word exterminate, be thought a harsh one. Both rich and poor ought to be exterminated: the latter by being made what we call rich; and the former by being brought to the common level." political economy was precisely the type of extremism that Southern reactionaries feared and led them to infer the failure of free society. To "unclench the hand of avarice, and make it give up its dishonest possessions," Skidmore urged a radical reconfiguration of the antebellum economy. ${ }^{79}$

\footnotetext{
${ }^{75}$ Skidmore, The Rights of Man to Property!, p. 37.

${ }^{76}$ Ibid., p. 136.

${ }^{77}$ Ibid., p. 4.

${ }^{78}$ Ibid., pp. 246-247.

${ }^{79}$ Ibid., pp. 228, 346.
} 
The first practical step in Skidmore's project was the abolition of inheritance. An individual's lease on property ended with death. Just as succeeding generations do not interfere with the destiny of those who have come before them, the dead have no claim over the destiny of the generations that follow them. God's resources shall be returned to a common pool upon an individual's death. "The system which I thus place before the world," Skidmore declared, "will rigidly maintain the principle, that no man or generation of men, have property, or the disposition of property, either as to who shall own, or shall not own it, or as to the use that shall be made of it, one moment after they cease to exist." ${ }^{\prime 80}$ Every adult member of society was entitled to the property of the deceased, placing each on an equal footing at the entrance of mature life.

The revolutionary character of Skidmore's agenda is difficult to exaggerate. He advocated a complete alteration of antebellum property rights. Skidmore, as one historian wrote, "carried the questioning and ambitious temperament of the American artisan radical to new heights...in a relentless assault on institutions and hierarchies even his most radical predecessors did not challenge." 81 To suggest, as Dorfman has, that Skidmore pursued "business ends" is inaccurate. ${ }^{82}$ Rather Skidmore expressed working-class hostilities toward the laissez-faire model. Dorfman's evaluation is based in part on Skidmore's support for tariffs. Dorfman failed to understand that Skidmore understood protective tariffs as a means to curtail what he perceived were the harmful effects of international competition. Skidmore's protectionism was not intended to advance the interests of industrial capitalists.

Neither is it entirely accurate to represent Skidmore's political economy as alien to an American free-market ideology consensus. In the antebellum economic discourse there were dozens of working-class intellectuals who echoed Skidmore's resistance to industrial capitalism

\footnotetext{
${ }^{80}$ Ibid., p. 121. Many of Skidmore's proposals are repeated in his shorter work, Moral Physiology Exposed and Refuted (New York, 1831).

${ }^{81}$ Wilentz, Chants Democratic, p. 187.

${ }^{82}$ Dorfman, "The Jacksonian Wage-Earner Thesis,” p. 300.
} 
and laissez-faire political economy. He found a receptive audience, too. On October 19, 1829 he presented his ideas to a New York's Working Men's Party convention. The party endorsed Skidmore's reforms and nominated him a candidate for the New York state assembly. When the final tallies of the 1829 election were counted Skidmore was short of victory by only twenty-three votes. $^{83}$

The Northern laborites and Southern reactionaries presented antebellum America with the most penetrating critique of the laissez-faire model, both as an intellectual system and a practical social/economic system. They constructed alternative paradigms to understand economic phenomena and both aimed to reconstitute the American economy without bourgeois capitalist institutions. The cerebral alliance between the two may be owed to what Holmes called the "anarchy and confusion" of the nineteenth-century discourse. ${ }^{84}$ Far from working under a freemarket consensus, the antebellum economic mind lacked clear ideological parameters.

It is also possible, within the context of the antebellum discourse that both groups genuinely believed they were advancing humanity's cause. The slave system advocated by the Southern reactionaries and the socialism of the Northern radicals sought to liberate the masses from the physical drudgery of industrial labor and the mental slavery of the cash nexus. In the antebellum discourse 'liberal' was largely appropriated by those who followed a Smithian brand of free-market economics. However, the Northern socialists and Southern reactionaries constructed economic visions that claimed to optimize human freedom. "The Socialists, the Communists" Holmes wrote, "are precisely those who most loudly proclaim their desire to establish a concentrated and consolidated government, which shall constantly interfere in all the

\footnotetext{
${ }^{83}$ Wilentz, Chants Democratic, pp. 195-198, 202-208; Pessen, Most Uncommon Jacksonians, pp. 60-61; Bronstein, Land Reform and Working-Class Experience, p. 42

${ }^{84}$ Holmes, "The Nineteenth Century," p. 466.
} 
affairs of private life...Yet this is...an indication of the progress of freedom." ${ }^{, 85}$ Socialism promised, according to Holmes' interpretation, emancipation from market forces, the end to labor's suffering, and mitigation of conditions that classical doctrine described as inevitable. In the logic of socialists like Byllesby and Skidmore, freedom from the natural economic order of Smith, Malthus and Ricardo represented the ultimate form of human liberty.

For the Southern reactionaries freedom was interpreted as safety from capital's exploit and security from want. The differences between the socialist understanding of liberty and that of the Southern reactionaries may be obvious to twenty-first-century historians. But in the context of antebellum economic thought the distinctions were not clear. "Socialism proposes to do away with free competition," Fitzhugh wrote, "to afford protection and support at all times to the laboring class; to bring about, at least, a qualified community of property, and to associate labor. All these purposes, slavery fully and perfectly attains. ${ }^{" 86}$ For Fitzhugh slavery was the most perfect form of socialism.

It was in this intellectual setting that American protectionism emerged. Protectionists, like the free-traders, the Northern laborites and the Southern reactionaries, constructed a political economy that promised to augment American freedoms. They argued that by restricting Smith's 'natural system of liberty' in international trade Americans would find their economic freedoms enlarged. In the antebellum discourse it would not have appeared especially contradictory for protectionists to argue for an economic system that preserved individual economic freedoms while simultaneously sealing off the domestic market from foreign competitors. Protectionists were, in this sense, championing an economic order that offered a different set of freedoms from those proposed by the Northern laborites and Southern reactionaries. Within the protectionist framework, restrictions were conceived as liberal, in the same way that the abolition of property

\footnotetext{
${ }^{85}$ Ibid., p. 466.

${ }^{86}$ Fitzhugh, Sociology for the South, p. 48.
} 
rights and the enslavement of the masses were perceived as human emancipation. When taken together, the various strains in American political economy illustrate that the domestic discourse functioned in its own particular cerebral sphere, one that can not be accounted for without reference to antebellum intellectual traditions. 


\section{Chapter VI}

Protectionism: An American Political Economy

The domestic treatment of Smithian free trade varied between regions, and Malthus and Ricardo were widely refuted by antebellum thinkers who wrote in the laissez-faire tradition. The Southern reactionaries and Northern laborites presented economic ideologies outside of the American mainstream, and neither organized into a bona fide school of political economy. In consequence, antebellum Americans expressed the desire for a distinctly native political economy. Protectionists believed they offered just that.

Protectionism was the antebellum period's most successful challenge to classical orthodoxy. It was also antebellum America's main contribution to the trans-Atlantic discourse. Alexander Hamilton fathered the movement, but it was not until the 1850s that protectionist thought was united under a coherent ideology by Henry Carey. During this period protectionism went through several stages of theoretical development. At each juncture, protectionists incorporated principles at the core of antebellum economic, political, and social culture. These included American exceptionalism, free-labor entrepreneurialism, national industrial development, and economic, political, and ideological independence from the Old World.

This chapter traces the intellectual development of antebellum protectionism. It identifies the origins of several key points of protectionist criticisms of laissez-faire economics, and shows how protectionism reflected important intellectual and cultural elements of the antebellum economic experience. Protectionism was the period's most authentic brand of American political economy. The progression of protectionism as an economic ideology corresponded to several seminal political and economic events of the period. Nationalism and domestic economic security were the principles that undergirded protectionism during its formative years. Throughout the antebellum period, protectionism was centered on questions of American 
sovereignty. The War of 1812 encouraged protectionists to elaborate on Hamilton's nationalist assertions. The collapse of the domestic economy following the peace at Ghent led protectionists to refine and expand their positions. These included the so-called infant industries argument, the claim that industrialization bolstered agricultural production, and the notion that tariffs benefitted American labor. The economic arguments were, however, secondary to assertions that protectionism secured the republic's political independence from Britain.

Protectionist thought was given additional stimulus during the nullification crisis. The spread of free-trade economics in the domestic discourse forced protectionists to sharpen their economic reasoning, become more critical of laissez-faire political economy, and connect economic policies to larger questions about the role of government in the antebellum economy. The nullification crisis also pushed protectionists to devise a more organic system of thought. Finally, the instability that characterized the antebellum economy during the 1830 s and 1840 s gave protectionists further impetus to polish the case behind high tariffs. By the 1850s the ideas of earlier protectionists were cultivate into a well-structured economic ideology that was ultimately crystallized in the writings of Henry Carey. ${ }^{1}$

Protectionism was also the economic ideology of American industrialization. It promised Americans industrial hegemony and economic security without the social hazards forecast by Malthus and Ricardo. In this way, the protectionists also anticipated the course of American politics. Originally aligned with the Whigs, Republicans later featured protectionism in their platforms before, during, and after the Civil War. Protectionist arguments provided Whig and Republican legislators the economic logic behind some of the world's highest tariffs of the

\footnotetext{
${ }^{1}$ The tariff played an important role in hostilities between North and South. Richard Bensel, Yankee Leviathan: The Origins of Central State Authority in America, 1859-1877 (Cambridge, 1990), p. 73, argues the tariff, along with other economic measures advanced by Republicans just prior to secession, aimed at undermining the Southern economy; Nicholas Onuf and Peter Onuf, Nations, Markets, and War: Modern History and the American Civil War (Charlottesville, VA, 2006), pp. 174-177, argue the tariff was central to the antagonistic views over national economic development.
} 
nineteenth century. ${ }^{2}$ But the protectionists also had a keen eye for American history. They argued British laissez-faire was incompatible with the course of American history, and developed instead what they regarded as an alternative grounded in the exceptional conditions of the American experience.

Although historians recognize the importance of tariffs to antebellum politics, they have largely ignored the ideology that undergirded protectionist thought. ${ }^{3}$ Much of what has been written on protectionism is by economic historians who approach the subject with a free-trade bias. ${ }^{4}$ These tend to minimize the value protectionists contributed to the antebellum discourse and they fail to appreciate protectionism as a cohesive economic ideology. They argue that the protectionist movement was orchestrated by industrialists, who for pecuniary advantage

${ }^{2}$ Richard Bensel, The Political Economy of American Industrialization, 1877-1900 (Cambridge, 2000); Paul Bairoch, Economics and World History: Myths and Paradoxes (Chicago, 1993).

${ }^{3}$ The exceptions are Frank Taussig, The Tariff History of the United States (New York, 1964); Percy Ashley, Modern Tariff History: Germany-United States-France (New York, 1970); Judith Goldstein, Ideas, Interests, and American Trade Policy, (Ithaca, N.Y., 1993); Richard Edwards, "Economic Sophistication in Nineteenth Century Congressional Tariff Debates," Journal of Economic History (December, 1970); Malcolm Rogers Eiselen, The Rise of Pennsylvania Protectionism (New York, 1974); Michael Hudson, Economics and Technology in $19^{\text {th }}$-Century American Thought (New York, 1975); Edward Stanwood, American Tariff Controversies of the Nineteenth Century (New York, 1974), vols. I and II; Joseph Dorfman, The Economic Mind in American Civilization, 1606-1865 (New York, 1946), vol. II; James Huston, Securing the Fruits of Labor: American Concepts of Wealth Distribution (Baton Rouge, LA, 1998).

${ }^{4}$ There is also an implicit judgment that the free-trade position occupied a higher moral plant. Jonathan Pincus, Pressure Groups and Politics in Antebellum Tariffs (New York, 1977), p. 1, begins his work on antebellum tariffs and political coalition building with the following: "The term 'Free trade,' like 'Virginity,' refers to one condition only, whereas 'Protection' covers a multitude, as does 'Sin.' This book is an investigation into the morphology of the sin of Protection, not into the conditions of a fall from Grace." See also Robert McGee, A Trade Policy for Free Societies: The Case Against Protectionism (Westport, CT, 1994), pp. vii-viii. "The only two kinds of trade are free trade and restricted trade...If trade is restricted because of some tariff, quota, or antidumping policy, it is the result of special interests (producers) going to the legislature to seek the hand of government to protect them from foreign competitors...protectionist policies are an abuse of governmental power." Also, Robert Nozick's quote found in Ibid, p. 4, "The illegitimate use of a state by economic interests for their own ends is based upon a preexisting illegitimate power of the state to enrich some persons at the expense of others." And W.M. Curtis found in Ibid, p. 4, "Through the years, some men have discovered how to satisfy their wants at the expense of others without being accused of theft: they ask their government to do the stealing for them." 
converted Congress into a paper mill for special interest legislation. ${ }^{5}$ While producer interests did contribute to tariff legislation, this interpretation gives much greater credence to free-trade ideas than Americans at the time did, and it ignores the complex of interests and thinkers who developed and supported the protectionist position.

The development of American protectionism began with Hamilton's 1791 Report on Manufactures. ${ }^{6}$ In it, Hamilton dispelled what was then the popular Physiocratic convention on the advantages of agriculture and the disadvantages of manufactures. Conditions in America, he admitted, gave the appearance that the nation was perfectly suited for agrarian pursuits, but that agriculture should be allotted, Hamilton argued, "any thing like an exclusive predilection, in any country, ought to be admitted with great caution." ${ }^{7}$ Hamilton's rebuke of Physiocracy was in essence a swipe at Jeffersonian agrarianism, and it helped establish legitimacy to industry in the domestic discourse. Second, Hamilton explained how the expansion of manufactures complimented agrarian economies by affording an "extensive domestic market for the surplus of the soil." ${ }^{8}$ Western and Southern agriculture was assured a steady home-market from Northern

\footnotetext{
${ }^{5}$ More recently, tariffs have been studied by political scientists through quantitative analysis, political coalition building, and evaluation of international trade theory. See Helen Milner and David Yoffie, "Between Free Trade and Protectionism: Strategic Trade Policy and a Theory of Corporate Trade Demand," International Organization (Spring, 1989); Edward Mansfield and Marc Busch, "The Political Economy of Nontariff Barriers: A Cross-National Analysis," International Organization (Autumn, 1995); Beth Yarbrough and Robert Yarbrough, "Cooperation in the Liberalization of International Trade: After Hegemony, What?," Benjamin Cohen and Charles Lipson, eds., Issues and Agents in International Political Economy: an International Organization Reader (Cambridge, MA., 1999); Robert Gilpin, Global Political Economy: Understanding the International Economic Order (Princeton, 2001).

${ }^{6}$ In the historiography, Alexander Hamilton is perhaps the only protectionist who has escaped neglect. A sample of the historiography on Hamilton includes Gerald Stourzh, Alexander Hamilton and the Idea of Republican Government (Stanford, 1970); Stanley Elkins and Eric McKitrick, The Age of Federalism: The Early American Republic, 1788-1800 (Oxford, 1993); Peter McNamara, Political Economy and Statesmanship: Smith, Hamilton, and the Foundation of the Commercial Republic (DeKalb, IL, 1998); Louis Hacker, Alexander Hamilton and the American Tradition (Westport, CT, 1957); E. James Ferguson, The Power of the Purse: A History of American Public Finance, 1776-1790 (Chapel Hill, NC, 1961).

${ }^{7}$ Alexander Hamilton, Report on Manufactures (1791), Henry Cabot Lodge, ed., The Works of Alexander Hamilton (New York, 1903),vol. IV, p. 71.

${ }^{8}$ Ibid., p. 98.
} 
industry, thus cementing the union into a harmonious economic and political relationship. Third, encouraging manufactures would increase America's productive capacity. Compared to husbandry, industry employed more machinery and capital, and it advanced the specialization of labor. Industry also brought idle women and children into the workforce. Finally, to critics who charged that tariffs inflated the price of manufactured wares, Hamilton reasoned that tariffs increased the number of domestic manufactures, enhanced competition, lowered prices, and prevented the establishment of monopolies. ${ }^{9}$

Nationalist and statist overtones saturate Hamilton's writings on tariffs. For Hamilton protectionism was as much a political doctrine as it was an economic policy. His brand of protectionism enhanced the economic authority of the sovereign. Hamilton linked a nation's political strength to its economic power. The surest path to defending American sovereignty was a strong domestic economy independent from international markets. This, Hamilton argued, would promote wholly American political institutions free of European influence. National security and national culture were central to Hamilton's protectionist program. ${ }^{10}$

The generation of economic writers who lived through the War of 1812 picked up and elaborated on Hamilton's economic nationalism. The conflict with Britain incited an insurgent nationalism that was precipitated by what contemporaries believed was an economic and political rivalry with Britain. ${ }^{11}$ Few could ignore the recurrent military hostilities between America and Britain. It was also evident that London and Washington engaged in a kind of commercial Cold War, both sides competing for markets and vying to better the other in their respective capacities for industry. Throughout the antebellum period, protectionists exploited nationalist and anti-

\footnotetext{
${ }^{9}$ Ibid., pp.85, 97, 95, 139, 84, 130-131.

${ }^{10}$ See for instance, Ibid., pp. 100-101. Liah Greenfield, The Spirit of Capitalism: Nationalism and Economic Growth (Cambridge, MA, 2001), pp. 386, 388-391, 396-397; Virgle Wilhite, Founders of American Thought and Policy (New York, 1958), p. 279.

${ }^{11}$ Onuf and Onuf, Nations, Markets, and War, pp. 17, 157-163.
} 
British currents then prevalent in American culture. ${ }^{12}$ Much of protectionist ideology hinged on anxieties that Britain threatened America's political and economic sovereignty. "We were," an American protectionist testified, "as much bound to Britain after the Revolution as before." ${ }^{13}$ Perceptions of Britain provided the superstructure on which protectionists based their theoretical claims. "What all have at present most to fear," a protectionist warned, "is the industrial supremacy of England." ${ }^{14}$ Britain was master of the economic universe to be guarded against with all that America could muster. "The gigantic power of England...the wonder of the world," that mighty nation was powerful enough to bring the world to its knees. ${ }^{15}$ "All states," a protectionist reported, "have a common interest in defending themselves against the damage that England, enjoying world economic supremacy, can arbitrarily inflict upon their industries." 16 Protectionists gave special emphasis to Britain's ability to undermine American sovereignty through economic imperialism. "Well might Napoleon dispense with arms when he had conquered the world; and well might Mr. Huskisson recommend free-trade when it would make the world tributary to England." ${ }^{17}$ The notion that British commercial policy intended an economic "war of extermination" drummed up fears, and protectionists were keen on manipulating this worry. ${ }^{18}$ Parliament, one protectionist wrote, sought to "revive the old system

\footnotetext{
${ }^{12}$ Steven Watts, The Republic Reborn: War and the Making of Liberal America, 1790-1820 (Baltimore, 1987), pp. xvii, 230-232, 310, 316; George Dangerfield, The Awakening of American Nationalism, 1815 1828 (New York, 1965); Roger Brown, The Republic in Peril: 1812 (New York, 1964).

${ }^{13}$ Nathaniel Ware, Notes on Political Economy: As Applicable to the United States by a Southern Planter (1844; reprint, New York, 1967), p. 217.

${ }^{14}$ Friedrich List, National System of Political Economy (1841; reprint, New York, 1974), p. 403.

15 "Memorial to the Senate" (1831), Alexander Everett, ed., Journal of the Proceedings of the Friends of Domestic Industry (1831; reprint, New York, 1974), p. 176.

${ }^{16}$ Friedrich List, The Natural System of Political Economy (1837; reprint, London, 1983), p. 47.

${ }^{17}$ Andrew Stewart, Speeches on the Tariff and on Internal Improvements (1872; reprint, New York, 1974), p. 167.
} 
of colonial dependence," capturing the young nation with a "manufacturing and commercial yoke." Economic policy was critical to assuring national sovereignty. Free trade with Britain meant Americans would essentially "cede their political power in order to render British productive and political power omnipotent." ${ }^{19}$

More than any figure Mathew Carey infused protectionist thought with an Anglophobic tone. Dublin born in 1760, Carey worked as a pamphleteer campaigning for Irish independence in his youth. In 1784 Carey's essays caught the attention of royal authorities who issued warrants for his arrest. He fled for America and eventually settled in Philadelphia. There he became one the nation's leading publishers and one of the founding members of the pro-tariff Philadelphia Society for the Promotion of National Industry. ${ }^{20}$ Carey was one of the principal figures in the early protectionist movement. He died in 1839 .

Carey did little to refine the economic logic behind protectionist ideology. However, the Anglophobic tone of his writings became a permanent staple in antebellum protectionist thought. Carey's works emphasized the need to protect American markets from British economic imperialism. His brand of protectionism was geared primarily at inciting anti-British fervor. American political culture was especially receptive of Carey's economic nationalism following the War of 1812. British industrial power, according to Carey, threatened America's independence. He wrote frequently of Irish suffering under British rule, cautioning Americans of the dangers that came with failing to guard their economic sovereignty. By opening its markets,

\footnotetext{
${ }^{18}$ List, National System of Political Economy, p. 378; Tench Coxe, A Brief Examination of Lord Sheffield's Observations on the Commerce of the United States in Seven Numbers with two Supplementary notes on American Manufactures (Philadelphia, 1792), pp. 33-40, 57-58.

${ }^{19}$ Friedrich List, Outlines of American Political Economy in a Series of Letters (1827),Margaret Hirst, ed., Life of Friedrich List, and Selections from His Writings (1909; reprint, New York, 1965), p. 178; Calvin Colton, The Junius Tracts (1844; reprint, New York, 1974), p. 37; List, National System of Political Economy, p. 62.

${ }^{20}$ Kenneth Rowe, Mathew Carey: A Study in American Economic Development (Baltimore, 1933), pp. 429435; Eiselen, The Rise of Pennsylvania Protectionism, p. 49.
} 
the United States, according to Carey, "have voluntarily adopted the colonial policy of England." ${ }^{21}$ All were aware of the current commercial warfare that existed between the United States and Britain. "It was vain for any man to shut his eyes against the active rivalship and persevering hostility of British manufacturers." 22

Carey's anti-British tune was carried into the latter half of the antebellum period by Calvin Colton. Born in 1789 in Massachusetts, Colton graduated from Yale and was later a Whig propagandist. He became something of a celebrity among Whigs with his partisan, ten-essay Junius Tracts published in 1840 . His major literary accomplishment, however, was a six-volume work The Life and Times of Henry Clay in $1846 .{ }^{23}$ He died in 1857.

Colton's seminal economic treatise Public Economy for the United States (1848) offered little akin to refined analysis. Instead, Colton stroked the nationalist key by exposing what he believed were British commercial policies aimed at colonizing the United States. It was "simply a question of justice, as the American revolution was a war of justice-and precisely, identically the same interests are at stake now as then. 'Free trade' would give up all which American independence acquired—all that is worth having." ${ }^{24}$ Colton believed he had uncovered British plans to sabotage America in Parliament debates. Lord Henry Broughman, an influential British statesman, was a favorite culprit for Colton. He believed Broughman's speeches evidenced a British plot. Speaking to the House of Commons in 1816 on the state of American industry, Broughman declared "it was well worth while to incur a loss upon the first exportation in order by the glut to stifle in the cradle those rising manufactures in the United States which the war had

${ }^{21}$ Mathew Carey, ed., Addresses of the Philadelphia Society for the Promotion of Domestic Industry (1820; reprint, New York, 1974), pp. 185, 189.

${ }^{22}$ Ibid., p. 152.

${ }^{23}$ For biographical information on Colton see Dorfman, The Economic Mind in American Civilization, 1606-1865, vol. II, pp. 777-779; Michael Hudson's Introduction in Colton's Public Economy for the United States (1848; reprint, New York, 1969), pp. v-xvi.

${ }^{24}$ Colton, Public Economy for the United States, p. 63. 
forced into existence contrary to the usual course of things. ${ }^{, 25}$ In this light, protectionists like Colton pictured the British threat; economic imperialists bent on undermining American sovereignty by exploiting the republic as a metropolis does its colony.

The threat of British economic imperialism was amplified by a supposed intellectual offensive on the American mind. Protectionists grew paranoid over the circulation of British laissez-faire on domestic soil. Carey estimated the works of Adam Smith and the French free trader Jean-Baptiste Say to have sold over 7,000 copies in America. These works, according to Carey, were intended "to paralyze our industry, and, to a certain degree, to render the United States virtually colonies of the manufacturing nations of Europe." ${ }^{26}$ Protectionists pointed to sinister forces to account for the dissemination of British laissez-faire in the domestic discourse. Free traders were instruments, accused one protectionist, of "British manufacturers and their agents and representatives." ${ }^{27}$ British free-trade imperialists had infiltrated Washington. "Our anti-tariff politicians," another wrote, "are as much playing into the hands of the English, in all their measures, as if the words were put into their mouths by England, and our laws penned by her too... No two nations ever existed, that could have played into each other's hands so completely, as this country and England." ${ }^{28}$

Colton, Carey and other protectionists sensed something akin to British intellectual imperialism. Before Smith, the British wrote exclusively in the mercantilist tradition. But once Britain became an industrial power its economists advocated laissez-faire. British cunning and deceit explained the transformation. "The doctrine of free-trade is a fraud, imposed upon the

\footnotetext{
${ }^{25}$ House of Commons, April 9, 1816. Found in Niles' Weekly Register, December 28, 1816, p. 284. For another example of Parliament debates cited in protectionist works, see Willard Phillips, Propositions Concerning Protection and Free Trade (1850; reprint, New York, 1968), p. 230.

${ }^{26}$ Mathew Carey, Autobiographical Sketches in a Series of Letters Addressed to a Friend (1829; reprint, New York, 1970), p. ix.

${ }^{27}$ Phillips, Propositions Concerning Protection and Free Trade, p. 163.

${ }^{28}$ Ware, Notes on Political Economy, pp. 97-98.
} 
world by pensioned writers for the benefit of Great Britain chiefly, which originated the fraud...Dr. Smith did not begin his Wealth of Nations till he was seduced from his high dignity at Glasgow...and became a beneficiary of the British government."29 With no American author was this belief held stronger to than by Colton. Smith, the "pensioned economist," perpetuated a "great conspiracy against mankind." "Was he not paid for it?" Colton asked. "And how should it happen that nearly all British writers on this subject, from Adam Smith down to this time, and nearly or quite nearly all the lecturers of the universities, and almost the entire periodical press...should have become one solid phalanx of Free-Trade advocates...This, certainly, is a very extraordinary spectacle." ${ }^{30}$

Protectionist suspicions over the legitimacy of laissez-faire were added to by nineteenthcentury British trade policy. Although British writers were at the fore of the laissez-faire movement, London promulgated mercantilist policies. ${ }^{31}$ For centuries, one protectionist reported, Britain kept her ports "hermetically sealed...If every bale and parcel of manufactures from every part of the world had been infected with the plague." ${ }^{32}$ Now that Britain was the industrial hegemon its economists clamored for free trade. ${ }^{33}$ "Here is the misfortune," Colton wrote, "the trick, as it might, with more propriety and truth, be called: Great Britain is the Jew, that has furnished other nations with books on political economy, to suit herself-not such as she follows,

${ }^{29}$ Calvin Colton, The Rights of Labor (1846; reprint, New York, 1974), p. 89.

${ }^{30}$ Colton, Public Economy for the United States, pp. 93, 94. Smith began researching and writing his Wealth of Nations while contracted as a tutor to the future third Duke of Bucchleuch,

${ }^{31}$ Britain abolished the Corn Laws in 1846.

${ }^{32}$ Alexander Everett, British Opinions of the Protecting System, Being a Reply to Strictures on that System, Which Have Appeared in Several Recent British Publications (Boston, 1830), p. 13.

${ }^{33}$ Colton, The Rights of Labor, p. 13; Carey, ed., Addresses of the Philadelphia Society, pp. 33-40; Horace Greeley, ed., The American Laborer (1843; reprint, New York, 1973),p. 277; George Tibbits, Essay on the Expediency of and Practicality of Improving of Creating Home Markets for the Sale of Agricultural Productions and Raw Materials by the Introduction or Growth of Artisans and Manufactures(1827), Carey, ed., Addresses of the Philadelphia Society for the Promotion of Domestic Industry, p. 19. 
but such as she wishes them to follow, and they are quoted in argument by American free-traders, who are, by this means, Jewed." The spread of laissez-faire literature was projected to advance British interest, so that she might "become the richest nation in the world—in that way, the most powerful—and to maintain that ascendancy." Free trade, another wrote, "had not been intended for home consumption. It had been intended for export." ${ }^{34}$ Modern historians find some legitimacy in this claim. "The parliamentary free traders," according to one historian, "strove not so much to achieve a cosmopolitan system...but to preserve Britain's industrial predominance, and, if possible, to achieve a virtual monopoly for a British Workshop of the World." ${ }^{35}$ An industrial and commercial Pax Britannica accomplished through free-trade policies and the proliferation of laissez-faire doctrine was according to protectionists calculated to undermine America's economic independence, and thus its political sovereignty.

Protectionist criticisms of British free-trade imperialism were typically combined with charges that laissez-faire political economy lacked scientific rigor. Smith was consistently targeted by protectionists. "Whilst he treats," one protectionist wrote, "detached matters with great ingenuity and experience, his system, considered as a whole, is so confused and distracted, as if the principal aim of his books were not to enlighten natives, but to confuse them for the benefit of his country..." ${ }^{36}$ Carey found that "in no science, are the general maxims of mere theorists more delusive, and more distrusted, than in political economy. This branch of knowledge is yet in its infancy...Its principles are not yet established. Those which have been considered as the most fixed, have been overthrown; those which have been taught as selfevident, are questioned; and the whole are subject of ardent discussion." Carey quoted Smith's

\footnotetext{
${ }^{34}$ Colton, The Rights of Labor, pp. 74, 89; List, The Natural System of Political Economy, p. 140.

${ }^{35}$ Bernard Semmel, The Rise of Free Trade Imperialism: Classical Political Economy, the Empire of Free Trade and Imperialism, 1750-1850 (Cambridge, 1970), p. 157; Timothy McKeown, "Hegemonic Stability Theory and $19^{\text {th }}$ Century Tariff Levels in Europe," International Organization (Winter, 1983).

${ }^{36}$ List, Outlines of American Political Economy, p. 148
} 
Wealth of Nations at length, arguing certain passages contained "much sophistry and unsound reasoning....and there is likewise, as in all the rest of the doctor's work, a large portion of verbiage, which is admirably calculated to embarrass and confound common understanding, and prevent their forming a correct decision. ${ }^{137}$

Protectionists also disparaged Smith and other laissez-faire economists for having indulged in speculative abstractions. Smith's background as an Enlightenment philosopher predisposed the Scotsman to metaphysical assumptions on human psychology and morality that clouded his assessment of economic systems. "The casual association of its teaching with moral philosophy," one protectionist alleged, "is the circumstance to which is to be attributed that metaphysical bias, manifested by almost all Economical writers, in their method of investigation, and which has conducted them to such vague, hypothetical, and unsatisfactory results. ${ }^{138}$ Deductive reasoning was, protectionists charged, a critical flaw in laissez-faire methodology. Public policy and a stronger regard for the empirical sciences were for protectionists important analytical tools in economic inquiry. "This science is in its nature essentially practical, and should be treated in a plain, practical way. Adam Smith, Mr. Say, and others who wrote upon this subject, were too abstract and theoretical for common use." ${ }^{39}$ Carey found Smith "to have been duped by his own system." ${ }^{40}$ A sophist confused by webs of abstractions and an idealist cosmopolitanism out-of-touch with real-world conditions. A "fool's gold," Colton wrote, "born in a closet" with assumptions passed off as natural laws, able only to "prove itself by itself." ${ }^{41}$ The freetrader was a "speculative professor, who concocts abstract theorems of political economy in

\footnotetext{
${ }^{37}$ Carey, ed., Addresses of the Philadelphia Society, pp. 182, 17.

${ }^{38}$ E. Peschine Smith, A Manual of Political Economy (1853, New York, 1974),p. iii.

${ }^{39}$ Ware, Notes on Political Economy, p. 1.

${ }^{40}$ Carey, ed., Addresses of the Philadelphia Society, p. 17.

${ }^{41}$ Colton, Public Economy for the United States, pp. 17, 20, 95.
} 
his closet." A doctrine "profligate, false, and absurd," based on "dreamy hallucination, made up of fallacies, sophistical assumptions," and unsound reasoning. ${ }^{42}$ "It is against such visionary projects, that we have raised our hands," Carey declared, "it is to warn you from the closet speculations of theorists, to invite you to common sense practice, founded on the nature of things." 43

Protectionist criticisms of the metaphysical tone of laissez-faire were indicative of the pragmatic bent of antebellum intellectual culture. The American knack for common sense was raised above the 'book wisdom' of laissez-faire philosophers. Distrust of the privileged, cloistered philosopher formulating abstract theories in an Ivory Tower was American custom. This attitude informed protectionist critiques of laissez-faire. By placing in the fore regard for American conditions and keeping as a central goal for economic inquiry the discovery of practical policy, protectionism conformed to domestic intellectual traditions. ${ }^{44}$ Protectionism, according to one historian, was an "economics of the street." ${ }^{45}$ The experimentalist, utilitarian, and policy-oriented tradition of Hamilton was raised above the 'enlightened economics' of Smith and the abstractions of Ricardo.

${ }^{42}$ Phillips, Propositions ConcerningProtection and Free Trade, pp. 8, 33, 108.

${ }^{43}$ Carey, ed., Addresses of the Philadelphia Society, p. 183.

${ }^{44}$ Since colonial times American economic thought valued practical measures over sophisticated theory. See E.A.J. Johnson, American Economic Thought in the Seventeenth Century (New York, 1961), pp. 9-11, 16, 27-29; John McCusker and Russell Menard, The Economy of British America, 1607-1789 (Chapel Hill, NC, 1991); Stephen Innes, Creating the Commonwealth: The Economic Culture of Puritan New England (New York, 1995); Arthur Schlesinger, "Ideas and the Economic Process," Seymour Harris, ed., American Economic History (New York, 1961), pp. 7-8; William Appleman Williams, "The Age of Mercantilism," The William and Mary Quarterly (October, 1958); Louis Hartz, Economic Policy and Democratic Thought: Pennsylvania 1776-1860 (Chicago, 1968); John Larson, Internal Improvement: National Public Works and the Promise of Popular Government in the Early United States (Chapel Hill, NC, 2001); Henry F. May, The Enlightenment in America (Oxford, 1976), pp. 121, 132, 342-346.

${ }^{45}$ J.F. Normano, The Spirit of American Economics: A Study of the History of Economic Ideas in the United States Prior to the Great Depression (New York, 1943), p. 196; Richard Hofstadter, AntiIntellectualism in American Life (New York, 1963); Clinton Rossiter, Conservatism in America (Cambridge, MA, 1982), pp. 50-52; John Ashworth, 'Agrarians' versus 'Aristocrats': Party Political Ideology in the United States, 1837-1846 (Cambridge, 1987),p. 14. 
The cultural tendencies that shaped protectionist skepticism of laissez-faire philosophy were reinforced by antebellum political events. During the Jacksonian era anti-intellectualism reached new heights. The egalitarian thrust of democracy engendered a culture where academics were suspect. A political mileu with an "I'm-as-good-as-you population" of equals raised few men's knowledge to esteemed levels. ${ }^{46}$ Alexis de Tocqueville noted this distinctly American quality. The "independence of the mind" led Americans "to mistrust the judgment of others, and to seek the light of truth nowhere but in their own understanding. Everyone then attempts to be his own sufficient guide, and makes it his boast to form his own opinions on all subjects." ${ }^{47}$ Accustomed to distrust the scholar's counsel, knowledge was sought not in books or philosophy but in home-grown intuition and folkish wisdom.

The pragmatic style of protectionist thought reflected American culture. But to reconcile the anti-theoretical, more pragmatic bent of antebellum culture with their own demands for scientific rigor protectionists incorporated into their works a bounty of economic data. ${ }^{48}$ Protectionists extolled the value of historical details in political economy. It served the dual purpose of toughening their claims to scientific legitimacy while simultaneously challenging the methodological approach of free-trade ideology. In doing so, the protectionists championed a methodological revolution in economic inquiry. While laissez-faire was based on "the invisible, the mysterious, the fluctuating internal nature" of moral philosophy and deductive reasoning,

\footnotetext{
${ }^{46}$ Fanny Trollope, Domestic Manners of the Americans (1832; reprint, London, 1997), p. 261; Edward Pessen, Jacksonian America: Society, Personality, and Politics (Homewood, IL, 1978),p. 28; Ann Douglas, The Feminization of American Culture (New York, 1998), pp. 37-42.

${ }^{47}$ Alexis de Tocqueville, Democracy in America (1835; reprint, New York, 2000),p 516.

${ }^{48}$ Edwin Seligman, Essays in Economics (New York, 1964), notes that the American interest in statistics was first taken by Samuel Blodget's, Economia: A Statistical Manual for the United States of America (1806). The American Statistical Association was founded in 1839. By the Civil War most states had bureaus for statistical accumulation; see Carl Abbot, Boosters and Businessmen: Popular Economic Thought and Urban Growth in the Antebellum West (Westport, CT, 1981), pp. 109, 111, 203.
} 
protectionism "pursued the opposite method; to have started from facts, and not assumptions." ${ }^{49}$

Protectionists steered economic inquiry away from abstraction. Argument by deduction,

protectionists believed, had skewed objective analysis and widened the gap between political economy and the positive sciences.

Historical statistics were for protectionists a natural bridge to economic history. Blending economic history with theoretical economics is one of the lasting contributions protectionists made to the trans-Atlantic discourse. The Historical School, that is, the enrichment of economic study by emphasizing history, institutions, sociology, politics, and culture became a seminal feature in American economic thought for the second-half of the nineteenth century. The historical economics movement materialized in 1885 when the American Economic Association adopted principles that stressed the historical economics of antebellum protectionist literature. ${ }^{50}$

Friedrich List is considered "the earliest example on American soil of the Historical School of Economic thought." ${ }^{51}$ Born in 1789 in Württemberg, List came to the United States in 1825 fleeing Prussian arrest for inciting German nationalism. He settled first as a farmer near Harrisburg, Pennsylvania, then Reading where he worked as a journalist until his return to Europe in 1832. After a series of literary and business failures List fell deathly ill and in 1846 committed suicide. List is remembered as the architect of the Zollverein, a customs union that brought

\footnotetext{
${ }^{49}$ Found in Michael Hudson's Introduction to Smith's A Manual of Political Economy, p. 11.

${ }^{50}$ Joseph Schumpeter, History of Economic Analysis (Oxford, 1954), pp. 808, 812; Joseph Dorfman, "The Role of the German Historical School in American Economic Thought," The American Economic Review (May, 1955); Richard Ely, "A Decade of Economic Theory," Annals of the American Academy of Political and Social Science (March, 1900), pp. 96-101; Dorothy Ross, The Origins of American Social Science (Cambridge, 1991), p. 110.

${ }^{51}$ William Notz, "Friedrich List in America," The American Economic Review (June, 1926), p. 264.
} 
eighteen German states under a single trade regime. In the words of one List scholar, he was "the driving force behind the Zollverein...In a very real sense he was the Alexander Hamilton. ${ }^{52}$

During his American sojourn List became a leader in the protectionist movement. ${ }^{53}$ By emphasizing historicism and a more relativist approach to economic theory, List further cemented protectionist ideology to American intellectual currents. For List, political economy comprised three distinct fields-philosophy, politics, and history. He argued that history was critical to political economy since it encouraged the formulation of economic theory based on national history. ${ }^{54}$ List expanded on the theoretical basis of the Hamiltonian matrix by renewing the association between national economic growth, industrial might, and political sovereignty. List imparted his vision in a series of letters prepared for the protectionist Harrisburg Convention in 1827. The letters were syndicated in over 50 newspapers and later compiled in his Outlines of American Political Economy.

As with Hamilton, List brought questions of national sovereignty to the fore of his political economy. "Between the individual and the whole human race there is the nation," List wrote. ${ }^{55}$ Citizens were bound to a common will that obligates individuals to contribute toward national economic power. Political sovereignty, List argued, rested on a nation's ability to control its economic destiny free from foreign, mainly British influence. Though expressed in economic terms, List's nationalist ideals were more political. They reflected a cultural statism

\footnotetext{
${ }^{52}$ Louis Snyder, The Roots of German Nationalism (Bloomington, IN, 1978), pp. 17, 2; W.O. Henderson, List, Economist and Visionary, 1789-1846 (Totowa, NJ, 1983), p. 145.

${ }^{53}$ William Notz, "Frederick List in America," p. 264; Ugo Rabbeno, American Commercial Policy (London, 1895), pp. 346-347; Schumpeter, History of Economic Analysis, pp. 807-812; Henry William Spiegel, The Growth of Economic Thought (Englewood Cliffs, NJ, 1971),pp. 421-424; Charles Gide and Charles Rist, History of Economic Doctrine, From the Time of the Physiocrats to the Present Day (New York, 1915), pp. 379-395; Seligman, Essays in Economics, pp. 15-16; Laurence Laughlin, "The Study of Political Economy in the United States," The Journal of Political Economy (December, 1892), pp. 6-8.

${ }^{54}$ Friedrich List, "Introduction to the National System of Political Economy," Life of Friedrich List, pp. 290-292.

${ }^{55}$ List, National System of Political Economy, p. 263
} 
typical of nineteenth-century German thought and an inclination growing within American protectionist circles. List argued the nation-state deserved special notice in political economy. "National economy," what List labeled his brand of economic thought, "teaches by what means a certain nation, in her particular situation, may direct and regulate the economy of individuals...to increase the productive powers within herself... a world within herself, in order to grow in power and wealth." ${ }^{56}$

List's influence in antebellum protectionism is indicative of the importance nationalist sentiment played during the formative years of the movement. List emphasized the role of the state in industrializing economies. Protectionists argued industrial development, and thus economic independence from stronger, more mature economies like Britain, required developmental policies aimed at advancing national industrial evolution. To achieve this end, domestic industrial forces required instructions from central government cognizant of the historical differences between nations. "Every nation," List argued in direct contrast to the universalism of free trade, "has its particular political economy." ${ }^{57}$ British laissez-faire, List argued, discounted the concept of nationalism and ignored the responsibility of the nation-state in advancing growth-oriented policies. ${ }^{58}$

List's national political economy helped refresh in antebellum protectionism a Hamiltonian/realist perception of international relations. Protectionist ideology took as a basic assumption a Hobbesian view of international relations. This was a diametrically opposed world view from British laissez-faire. ${ }^{59}$ Free-traders posited a world moving toward peace, harmonious trade, and a fraternal order where nations were obsolete. "In the actual world," List wrote,

\footnotetext{
${ }^{56}$ List, Outlines of American Political Economy, p. 155.

${ }^{57}$ List, Outlines of American Political Economy, p. 203.

${ }^{58}$ Onuf and Onuf, Nations, Markets, and War, pp. 157-170, 261-262; Liah Greenfield, The Spirit of Capitalism: Nationalism and Economic Growth, pp. 200-203.

${ }^{59}$ Onuf and Onuf, Nations, Markets, and War, pp. 247, 260.
} 
humanity was divided into nations violently competing for economic power. ${ }^{60}$ To defend American sovereignty from foreign aggression List advocated well-measured trade policies that favored national industry over personal interests. Laissez-faire only considered "how the economy of the individual and of mankind would stand if the human race were not separated into nations." Failure to appreciate the essential correlation between individuals and nations, and moreover the centrality of the nation-state in the modern world, List found laissez-faire misguided by "a chimerical cosmopolitism, which does not comprehend nationality, and has little regard for national interest." ${ }^{61}$ List elevated the nation over the individual. In his communalistic brand of political economy, coordination and cooperation at the national level were essential. Economic policy ought to promote national concerns, nurture a nation's productive powers, and if necessary, restrict personal behavior. "An individual, in promoting his own interest, may injure the public interest; a nation, in promoting the general welfare, may check the interest of a part of its members. But the general welfare must restrict and regulate the exertions of individuals." ${ }^{62}$

The emphasis protectionists gave to national economics marks an important ideological breach with the laissez-faire tradition. List was not concerned with maximizing private wealth. He believed there was a higher, national calling for the burgeoning science. Rather than instruct individuals on how to amass personal fortunes, political economy should focus on national economic policy. The writings of List and other antebellum protectionists stressed the interplay between economic and political institutions. "The Scot's theory," List wrote, "in spite of the very name they chose to give their science, they will make us believe that there is nothing of politics in political economy. If their science is properly called 'political economy,' there must be just as much 'politics' in it as 'economy,' and if there is no 'politics' in it, the science has not got the

\footnotetext{
${ }^{60}$ List, National System of Political Economy, p. 200.

${ }^{61}$ Ibid., p. 262.

${ }^{62}$ List, Outlines of American Political Economy, pp. 215, 212.
} 
proper name, it is nothing else than economy." ${ }^{63}$ Protectionists challenged the standard free-trade maxim that political and economic inquiries were two distinct fields of study. ${ }^{64}$ Political economy, List argued, "should be concerned as much with politics as with economics." 65

On this point List was not entirely original. His visit to the United States came just after the publication of the first treatise on political economy written in America. Daniel Raymond published in 1820 his Thoughts on Political Economy. Raymond issued a second edition with significant revisions under the title The Elements of Political Economy in 1823. John Adams wrote to Raymond that he had "never read any work upon Political Economy with more satisfaction," and that the book stood as "a proud monument of American literature." Raymond's work did not reach a wide audience. Only 750 copies were issued and of that number over 200 were sold at auction. Born in Connecticut in 1786, Raymond attended the prestigious Litchfield Law School and eventually settled in Maryland where he was accepted to the bar in the Baltimore County Court. In 1842 he moved to Cincinnati and established a weekly paper, but the endeavor lasted less than six months. He died in 1849 of cholera. ${ }^{67}$

A romantic nationalist sentiment guided Raymond's economic thought. He treated economics from a research paradigm squarely at odds with the laissez-faire tradition. "Political

${ }^{63}$ Ibid., p. 161.

${ }^{64}$ J.B. Say, the leading French disciple of Smith, declared the divorce between political studies and economic science in his 1803 Treatise on Political Economy. "Since the time of Adam Smith, it appears to me, these two very distinct inquiries have been uniformly separated; the term political economy now being confined to the science which treats wealth, and that of politics, to designate the relations existing between a government and its people, and the relations of different states to each other." Treatise on Political Economy (Boston, 1824), pp. xix-xx. Say's work was standard reading for American free traders. Michael O'Connor, Origins of Academic Economics in the United States (New York, 1974), pp. 23, 121, 124.

${ }^{65}$ List, TheNaturalSystem of Political Economy, p. 40.

${ }^{66}$ Adams to Daniel Raymond, Feb. 8, 1821, "Preface to the Third Edition," Daniel Raymond, The Elements of Political Economy (1823; reprint, New York, 1964), vol. I, p. v.

${ }^{67}$ For biographical information on Raymond see Donald Frey, "The Puritan Roots of Daniel Raymond's Economics," History of Political Economy (Fall, 2000); C.P. Neil, Daniel Raymond: An Early Chapter in the History of Economic Theory in the United States (New York, 1974), pp. 47-49. 
economy is a science which teaches the nature and causes of public or national wealth...the means of promoting a nation's wealth..." ${ }^{68}$ Raymond anticipated List by censuring free traders for being fixated on the individual accumulation of riches. "Instead of treating public economy they in fact treat private economy; instead of talking about nations they talk about individuals." ${ }^{69}$ Private economy reflected an individual's temporary, pecuniary interests. Political economy, on the other hand, was for Raymond the science of the legislator. In Raymond's vernacular, political economy took into account that a nation might last into perpetuity. The science was not a secondrate branch of knowledge for private interests; rather it dealt with more important issues that effected national conditions and the public's well-being.

Raymond's definition of what constituted political economy illustrated the ideological differences between protectionism and laissez-faire. By confusing private and public economy, the free traders had also obscured the differences between national and individual wealth. For Raymond, private wealth and national wealth were radically different concepts. "It is most unfortunate that for the science of political economy, that the word wealth has been applied indiscriminately, to nations and to individuals." ${ }^{70}$ Private wealth was defined by Raymond as an individual's possession of property to obtain the necessities and comforts of life. National wealth was comprised of a number of elements-political, economic, social and cultural-that contributed toward national production in the present and future.

The basic error regarding individual and national wealth led to other points of confusion regarding private and public interests, according to Raymond. Laissez-faire assumed what was good for the individual was beneficial to the nation. Raymond found this association erroneous. An individual's interest could be opposed to a nation's interest, just as the nation's prosperity may

\footnotetext{
${ }^{68}$ Daniel Raymond, Thoughts on Political Economy (Baltimore, 1820),p. 9

${ }^{69}$ Ibid.,p. 58.

${ }^{70}$ Raymond, The Elements of Political Economy, vol. I, pp. 47-50, 33.
} 
be detrimental to an individual's private economy. "The sophistry of Dr. Smith's reasoning consists in a great measure," Raymond wrote, "in his not discriminating between national and individual interests. He considers the interests of some particular class of citizens, as identical with the interests of the nation, when in reality they are, perhaps, directly opposed." ${ }^{71}$ The failure of laissez-faire to provide clear direction for legislators on how best to increase national wealth originated in its reasoning from individuals to nations.

Like Hamilton, Raymond's political economy transmitted the concerns of a newly independent nation still debating the role of the sovereign. Personal economic freedoms were not sacred, particularly if they undermined national interests. Government had the right and obligation to place the national economy ahead of its citizens. "It is ever to be remembered," Raymond wrote, "that the public interests are paramount to individual interests...that when a political economists has shown that public and private interests are opposed...the interposition of the government is necessary-he cannot be required to prove that private interests ought to give way-this is to be taken for granted." ${ }^{72}$

Both List and Raymond echoed antebellum nationalist currents, particularly in the North, by emphasizing the role of government in the development of emerging economies. But it was List who entreated Americans to recognize that the United States was perfectly situated to assert its economic independence. Indeed, America was presented with an "unexampled" opportunity to control its economic destiny. "The condition of this nation cannot be compared with the condition of any other nation," List declared. ${ }^{73}$ Like many antebellum foreign visitors, List articulated a feeling that the American experience offered something positively different. A number of laissez-faire thinkers employed American exceptionalism to counter Malthus and

\footnotetext{
${ }^{71}$ Daniel Raymond, The Elements of Political Economy (1823; reprint, New York, 1964), vol. II, p. 228.

${ }^{72}$ Ibid, vol. II, p. 201.

${ }^{73}$ List, Outlines of American Political Economy, pp. 166-167.
} 
Ricardo. These laissez-faire economists did not, however, make American exceptionalism a foundational element of their ideology.

More than any antebellum school of economic thought the protectionists made American exceptionalism a central tenet in their political economy. Protectionists combined socially accepted notions regarding the exceptionality of America's historical, political, and economic conditions to challenge classical assumptions and construct an explicitly optimistic economic philosophy. ${ }^{74}$ In doing so, they aligned protectionism with a seminal feature of America culture. Unlike the antebellum free traders, the protectionists relied heavily on American exceptionalism to advance their understanding of economic phenomena, but they also incorporated the concept to defend their vision of economic development.

Protectionists pointed to several political, social, and cultural elements that contributed to America's distinct historical standing. First, the nation's democratic institutions promised unprecedented economic opportunity. Protectionists reflected antebellum cultural assumptions regarding the wide-spread benefits of democracy, and they incorporated the economics of democracy into their ideology. Protectionism grew increasingly popular in the 1830 s and 1840 s precisely during the so-called 'Age of Democracy. ${ }^{75}$ Protectionists believed democratic government was genuinely responsible to the people's demands. "Government is instituted to

\footnotetext{
${ }^{74}$ On American exceptionalism see Seymour Lipset, American Exceptionalism: A Double-edged Sword (New York, 1996); WenerSombart, Why There is no Socialism in the United States? (White Plains, N.Y., 1976); Deborah Madsen, American Exceptionalism (Jackson, MS, 1998); Jonathan Glickstein, American Exceptionalism, American Anxiety: Wages, Competition, and Degraded Labor in the Antebellum United States (Charlottesville, VA, 2002).

${ }^{75}$ Richard P. McCormick, The Second American Party System: Party Formation in the JacksonianEra (New York, 1966); Sean Wilentz, The Rise of American Democracy, Jefferson to Lincoln (New York, 2005), p. 309. On the expansion of the suffrage before and during the Jacksonian era see Lee Benson, The Concept of Jacksonian Democracy, New York as a Test Case (New York, 1967); Dixon Ryan Fox, The Decline of Aristocracy in the Politics of New York, 1801-1840 (New York, 1965); Robert Remini, Andrew Jackson and the Course of American Democracy, 1832-1845 (New York, 1984); Edward Pessen, Riches, Class, and Power Before the Civil War (Lexington, MA, 1973).
} 
guard the interests of the nation confided to its care," Carey wrote. ${ }^{76}$ Carey considered the tariff an honest effort to defend through democratic means the economic prerogatives of constituents. In this way protectionism revealed the nation's political milieu and might be considered a form of economic democracy. Their confidence in democratic institutions was premised on a belief in American exceptionalism. The United States was the first nation with an enlightened majority willing to sacrifice their economic interests for the common good. But the United States was also exceptional because its legislators were responsive to voters. British laissez-faire mistakenly assumed that political interference in the economy was adverse to the public's interests.

Protectionists argued that the anti-statist tone of laissez-faire was a natural reaction to experiences under the Old Regime. However, Americans had no reason to dread state meddling in the economy. The constitution itself, Colton posited, was "enacted for the purpose of establishing a protective policy...to protect the persons and rights of people. ${ }^{177}$ In protectionist ideology the strong arm of government was not feared. ${ }^{78}$ A positive state promoted prosperity, facilitated industrial development, and served as a paternal figure in the economy. Its principal function was to aid the people. For Raymond, this meant providing Americans with employment. "So it is the duty of the legislator to find employment for all people, and if he cannot find them employment in agriculture and commerce, he must set them on manufacturing. ${ }^{79}$

The historical uniqueness of American democracy made for economic and social conditions that were equally distinct. Protectionists celebrated these distinctions as essential

\footnotetext{
${ }^{76}$ Carey, ed., Addresses of the Philadelphia Society, p. 86; see also Mathew Carey, The New Olive Branch: or, an Attempt to Establish and Identity of Interest Between Agriculture, Manufactures and Commerce (1821), Essays on Political Economy, or the Most Certain Means of Promoting the Wealth, Power, Resources, and Happiness of States Applied Particularly to the United States (1822; reprint, New York, 1968), p. 376.

${ }^{77}$ Colton, The Rights of Labor, pp. 15-16.

${ }^{78}$ Edwards, "Economic Sophistication in Nineteenth-Century Congressional Tariff Debates," pp. 815, 820.

${ }^{79}$ Raymond, The Elements of Political Economy, vol. II, p. 242.
} 
qualities of American exceptionalism. The absence of aristocratic institutions fashioned a landscape free of rank and hereditary privilege, abound with social mobility, and an equality of access to a vast continental expanse where every citizen could fulfill republican dreams of proprietorship and economic independence.

American exceptionalism also contributed to protectionist understanding of the historical uniqueness of domestic labor. The celebration of American labor was palpable in Northern economic literature. The American worker, if protected by high tariffs, had no reason to fear the dismal conditions described by Malthus and Ricardo. Indeed, in an American fortress no sector of the population was promised greater prosperity than the laboring classes. By the 1850 s labor was raised to the pinnacle of American economic, social, and political life, especially in Whig and Republican circles. ${ }^{80}$ Labor was thought as an instrument for self-advancement, the source of all value, the fountain of improvement and the cause of civilization's progress. Labor was not demoralized by endless competition, nor the unfortunate result of Adam's curse. Rather, it was a dignified calling eagerly and voluntarily responded to by all. ${ }^{81}$

Free-labor ideology was one of the sacred principles of protectionism, and it brought protectionists further in-line with American cultural traditions. ${ }^{82}$ The use of free-labor mythology in protectionist thought was not a form of industrial/capitalist apologetics. Neither was it a dishonest effort to capitalize politically on the assumptions of naive workers. Instead,

\footnotetext{
${ }^{80}$ Foner, Free Soil, Free Labor, Free Men, pp. 12-17; Huston, Securing the Fruits of Labor, pp. 175-178, $187,248-251$.

${ }^{81}$ American labor mythology stretches to colonial times. See John Smith, A Description of New England (1616), Marianne Johnson, Steven G. Medema, and Warren J. Samuels, eds., Foundation of the American Economy: The American Colonies from Inception to Independence. From Theocracy to Secular, Materialist Commercial Society (London, 2003), vol. I, pp. 10, 18.

${ }^{82}$ James Huston, The Panic of 1857 and the Coming of the Civil War (Baton Rouge, LA, 1987), p. 101; G.B. Mangold, The Labor Argument in the American Tariff Discussion (New York, 1974); Huston, Securing the Fruits of Labor, pp. 175-176, 248-250; Daniel Walker Howe, The Political Culture of the American Whigs (Chicago, 1979),p. 190.
} 
protectionists hoped tariffs would soften the social externalities of industrialization. ${ }^{83}$

Protectionism was as much a social creed as it was an industrial one. ${ }^{84}$ Protectionist sympathy for labor illustrated a producer/collectivist mentality that was shared by many antebellum Americans. They argued British laissez-faire overestimated the importance of distribution and therefore failed to acknowledge that the essence of men lay in the fruits of their labor. Malthus and Ricardo taught that labor was an instrument of capital, the human spirit behind labor's production a materialistic reaction to satisfy base desires. "In the eyes of modern political economy he [labor] is nothing, and can be nothing, because it takes no note of the qualities by which he is distinguished from the brute." ${ }^{85}$ For protectionists man was a producer first, then a consumer. The protectionists however, did more than purport a germane version of free-labor ideology. They infused the labor theory of value with moral authority. The American worker, Colton argued, "occupies an elevated, influential, honorable position." 86 To toil was the American fashion, that which provided one distinction. "Labor, work, is the spirit, the genius of the American people. It was so from the beginning by of necessity; it became a fixed habit of the community; and has ever been a part of the morale of the country." ${ }^{87}$ The founding of the new republic had ushered "a new era of labor...the true millennium of labor." ${ }^{88}$ Only after the revolution from Britain was labor able to exercise its long-dormant republican virtue. "The

\footnotetext{
${ }^{83}$ James Huston, "The Political Response to Industrialism: The Republican Embrace of Protectionist Labor Doctrine," The Journal of American History (June, 1983).

${ }^{84}$ Karl Polayni, The Great Transformation: The Political and Economic Origins of Our Times (Boston, 2001), pp. 160-162; Jeffrey Sklansky, The Soul's Economy: Market Society and Selfhood in American Thought, 1820-1920 (Chapel Hill, NC, 2002); Tony Freyer, Producers versus Capitalists: Constitutional Conflict in Antebellum America (Charleston, VA, 1994); John Ashworth, Slavery, Capitalism, and Politics in the Antebellum Republic: Volume I, Commerce and Compromise (Cambridge, 1995), p. 493.

${ }^{85}$ Henry Carey, Principles of Social Science (1858; reprint, New York, 1963), vol. I, p. 31.

${ }^{86}$ Colton, Public Economy for the United States, p. 281.

${ }^{87}$ Ibid., p. 282.

${ }^{88}$ Colton, The Junius Tracts, p. 106.
} 
breaking of the British scepter was the installation of American labor in its rights; it was the foundation of an empire of working men; and from that hour labor has been the great political power of the country. The event was a jubille-the jubille of labor." 89 The political leverage provided domestic labor with social and economic power. In the American republic of labor, the worker was not simply the handmaiden of capital. Labor acted as an "independent agent." 90 Indeed, capital courted labor; it was dependent upon labor; labor was its master. In this environment labor, "does not accept a price imposed but commands its own price." ${ }^{11}$ Capital, however, had nothing to fear about labor's power. Domestic conditions made anxieties over class conflict a moot point. Protectionists were keen on dispelling Ricardian assertions of class conflict.

In their celebration of free labor, protectionists presented a radically different narrative from classical orthodoxy. Protectionists assumed a progressive American working class that took advantage of the nation's easy upward mobility. Indeed, capital and labor shared identical interests; they were essentially one in the same. ${ }^{92}$ High tariffs engaged workers and capitalists in a mutually beneficial relationship where increasing wages corresponded to augmented production and did not infringe on profits. "That the interests of the capitalist and the laborer are thus in perfect harmony with each other," one protectionist reported, "as each derives advantage from every measure that tends to facilitate the growth of capital." ${ }^{13}$ Writing in 1844, Colton declared "That every American laborer can stand up proudly, and say, I AM THE AMERICAN

${ }^{89}$ Colton, Public Economy for the United States, pp. 282-283.

${ }^{90}$ Colton, The Rights of Labor, p. 7.

${ }^{91}$ Colton, The Junius Tracts, p. 105.

${ }^{92}$ Louis Hartz, The Liberal Tradition in America: An Interpretation of American Political Thought since the Revolution (New York, 1955), pp. 108-112; John Ashworth, 'Agrarians' versus 'Aristocrats', pp. 6569; Richard Hofstadter, The American Political Tradition and the Men Who Made It (New York, 1974), pp. 132-135.

${ }^{93}$ Carey, Principles of Political Economy, vol. I, p. 339; see also vol. II, p. 310. 
CAPITALIST, which is not a metaphor, but a liberal truth." ${ }^{94}$ The social and economic divisions imagined by British free traders did not exist in America. In protectionist thought, there was no reason for labor to rebel, and thus no reason for capital to shrink from the laboring masses. By strengthening labor, the rule of law and the sanctity of property were not jeopardized. ${ }^{95}$ Indeed, higher wages, according to one protectionist, promised "a steady improvement in the condition of both laborer and capitalist. That the former, while enjoying a constantly increasing measure of the comforts and conveniences of life, experiences a constantly increasing facility in becoming himself a capitalist." 96

In protectionist logic, the power of labor was made possible by the availability of western lands. The safety-valve theory, widely accepted in Northern intellectual culture, was a standard assumption of antebellum protectionism. It is also another clear indication that features of American exceptionalism were critical to protectionist ideology. ${ }^{97}$ The condition of domestic labor was unique precisely because it had access to an expanse of unclaimed territory. Access to Western lands inhibited European-style pauperism for American workers by affording labor an alternative. The safety-valve concept contributed to protectionist arguments that American industrialization would follow a course that was fundamentally different from that posited by British laissez-faire.

Protectionism reflected American economic culture in still other ways. Protectionism was the only school in the antebellum discourse that championed the rapid and comprehensive industrialization of the American economy. The exceptionality of American historical

\footnotetext{
${ }^{94}$ Ibid., p. 106.

${ }^{95}$ Alexander Everett, "Address of the Friends of Domestic Industry Assembled in Convention at New York, Oct. 26, 1831, to the People of the United States," Journal of the Proceedings of the Friends of Domestic Industry, p. 21.

${ }^{96}$ Henry Carey, Principles of Political Economy (1837; reprint, New York, 1965), vol. I, pp. 142-143, 76, 78; Greeley, ed., The American Laborer, pp. 237-239.

${ }^{97}$ Henry Smith, Virgin Land: The American West as Symbol and Myth (New York, 1957), p. 240.
} 
circumstances, the unique conditions of domestic labor, and the harmony that existed between labor and capital contributed to protectionist optimism over the expansion of industry. Contrary to the Southern free traders, the Southern reactionaries like Fitzhugh and Holmes, and the Northern laborites, industrialization promised wide-spread benefits. Industrialization guaranteed national economic and political sovereignty. Carey argued that industry advanced society by cultivating the sciences, the arts and literature, and served as "the only sure foundation of national virtue, happiness, and greatness." ${ }^{98}$ Manufactures were, according to one protectionist, "the great agents and tokens of the increase of national opulence, and the progress of civilization." 99 Neither did domestic labor have anything to fear over industrialization. Industrial workers gained the most. According to Colton, industrial labor was provided "the best state of health in body and mind... What industrial calling has not its quiet aspects by day, and its refreshing sleep at night?"100

Despite protectionist glorification of industry, many Americans believed the nation's future wealth rested on its comparative advantage in agriculture. Protectionists were, therefore, compelled to explain how industry could advance without threatening agriculture's place in American culture. Indeed, America was such an exception that agriculture and industry could development in harmony. The growth of industry subtracted from what protectionists believed was an overstocked labor supply in agriculture. This increased domestic demands for the farmer's labor. Industrialization also provided a home market for agrarian produce. Operatives in search of food, as well as industrialists in search of raw materials, guaranteed a steady market for domestic agriculture. To bring, in the words of one protectionists, "the loom and the anvil to take

\footnotetext{
${ }^{98}$ Carey, ed., Addresses of the Philadelphia Society, p. 22.

${ }^{99}$ Francis Bowen, The Principles of Political Economy Applied to the Condition, and the Resources of the American People (1856; reprint, New York, 1974), p. 91.

${ }^{100}$ Colton, The Junius Tracts, p. 106.
} 
their natural place by the side of the plough and the harrow." ${ }^{101}$ Carey argued that without an industrial sector the future of American agriculture was jeopardized. ${ }^{102}$ Farmers and planters saw their products carried from port to port seeking buyers, expending great costs in transportation, and ultimately sold at dock-side auctions. Foreign markets were glutted with American agriculture, precipitating a fall in commodity prices and the exhaustion of domestic soils. "The system of foreign trade, of itself, necessarily tends to impoverish the land already under cultivation...in order to maintain its rate of production." ${ }^{103}$ The expansion of domestic industry even benefited Southern planters. "It will then have a home market," one protectionist declared, "there is no interest that ought to hail the establishment of manufactures louder than this."104

The home-market argument posited not only the preservation of agriculture's predominance, it also served commercial interests. Protectionists crafted arguments that appealed to a variety of economic sectors. They assured the public that merchants and industrialists were not rivals competing for a fixed income fund. Rather industrialization expanded the merchant's share of national wealth by opening new trading opportunities. Coastal and internal trade would increase if food staples and raw materials from the South and Mid-West were provided industrial markets in the Northeast. ${ }^{105}$

\footnotetext{
${ }^{101}$ Henry Carey, The Harmony of Interests Agricultural, Manufacturing, and Commercial (1851; reprint, New York, 1967), p. 190.

102 Carey, The New Olive Branch, Essays on Political Economy, p. 343.

${ }^{103}$ Smith, Manual of Political Economy, p. 203.

${ }^{104}$ Ware, Notes on Political Economy, pp. 124-125; Mathew Carey, "Address to Congress" (1820), Essays on Political Economy, pp. 386, 400-401, 407; Mathew Carey, "Preamble and Constitution of the Society for the Promotion and Encouragement of American Manufactures" (1829), Autobiographical Sketches in a Series of Letters, pp. 120, 141.

${ }^{105}$ Tench Coxe, A Statement of the Arts and Manufactures of the United States of America for the year 1810 (Philadelphia, 1814), pp. xx-xxi; Tibbits, Essay on the Expediency, p. 48; Carey, ed., Addresses of the Philadelphia Society, pp. 61-64.
} 
The emphasis given to the home-market drew protectionists into the logic of isolationism. "Protection looks homeward. Free trade, under existing circumstances, looks abroad." ${ }^{106}$ The isolationist tone of protectionist thought was colored with a patriotic zeal that reflected antebellum notions of nationalism and Anglophobia. ${ }^{107}$ No nation's economic sovereignty was assured without a self-sufficient, interdependent domestic market. "Home consumption, and a home market," Raymond wrote "is, therefore, always to be preferred to a foreign one."108 Economic isolationism was consistent with an over-arching view that the world was a dangerous place. "The occasional occurrence of war...must be calculated on as inevitable." In protectionist ideology international markets were characterized by conflict and fluctuation. "Every alternative year," one protectionist figured, "has been on an average a year of war." ${ }^{109}$ Protectionists called for Americans to shun the outside. "All people must look at home first, and stop not short of securing the home market in its fullest extent to themselves... The home market is like an inherited patrimony; we may claim it as belonging to us, as of right ours." 110

Isolationism in the protectionist context was a by-product of American exceptionalism. "No nation, ancient or modern," Carey argued, "ever possessed more solid advantages than are here enumerated."111 Colton agreed, declaring "Never, in the history of the world, did a nation

${ }^{106}$ Carey, Harmony of Interests, p. 196.

${ }^{107}$ For anti-British sentiment in antebellum thought see Cook, J.G, Anglophobia: An Analysis of AntiBritish Prejudice in the United States (Boston, 1919).

${ }^{108}$ Raymond, Thoughts on Political Economy, p. 128; see also Smith, Manual of Political Economy, p. 216; Phillips, Protection and Free Trade, p. 202.

${ }^{109}$ Everett, British Opinions on the Protecting System, p. 41.

${ }^{110}$ Ware, Notes on Political Economy, p. 88.

${ }^{111}$ Mathew Carey, "Address to the Farmers of the United States on the Ruinous Consequences to their Vital Interests of the Existing Policy of this Country" (1821), Essays on Political Economy, p. 414; Mathew Carey, "Report of the committee of commerce and manufactures, to which were referred the memorials and petitions of the manufacturers of cotton wool," Addresses of the Philadelphia Society, p. 145; Mathew Carey, "Report of a Philadelphia Committee: Americana Manufactures" (1816), Essays on Political Economy, pp. 226-227. 
occupy such a position, or have within its reach such means of wealth and power, as the United States." ${ }^{112}$ The exceptional conditions existing in America afforded the potential for absolute economic independence. "As if America were not a world in itself, and able by its ingenuity and skill to supply every luxury, as well as every necessity," Colton wrote. ${ }^{113}$

Protectionists grew increasingly isolationist both economically and intellectually as the antebellum period came to a close. "For the most part, ours is a different world from theirs," Colton declared, "things here started different, have grown up different, and are different." 114 This attitude reflected a domestic desire to break from the Old World. Raymond believed his was the first economic treatise for the new nation. He aimed to divorce America, in his own words, "from the fetters of foreign authority-from foreign theories and systems of political economy."115 The American school, as the protectionists called themselves, believed Old World economists were too prejudiced by their social and political institutions to devise economic theory applicable to the American experience. "It is morally impossible from the social position of European economists," Colton wrote, "that they should be able to adopt a system of political economy to America." ${ }^{116}$ Laissez-faire ideology was simply irrelevant in the United States. Neither did laissez-faire convey an accurate understanding of economic phenomenon. American conditions, according to Raymond, engendered markets of the purest form, unaffected by corrupt human institutions and artificial impediments. Here the clearest manifestations of the natural economic

\footnotetext{
${ }^{112}$ Colton, Public Economy for the United States, p. 536.

${ }^{113}$ Colton, The Rights of Labor, p. 75.

${ }^{114}$ Colton, Public Economy for the United States, p. 156.

${ }^{115}$ Raymond, Thoughts on Political Economy, p. v.

${ }^{116}$ Colton, The Rights of Labor, p. 4.
} 
order allowed American thinkers "much greater advantages for studying the science of political economy than Europeans."117

The New World demanded a new political economy that reflected the distinct history and reality of the American economic experience. For many Americans protectionism was that system. As we see in the following chapter, Henry Carey crystallized protectionist ideology by bringing a sense of intellectual continuity to the variety of positions that made up the lexicon of antebellum protectionism. In doing so, he provided the antebellum period with its most formidable theoretical challenge to laissez-faire economics, one that for many Americans represented the sharpest expression of the native economic mind.

${ }^{117}$ Raymond, The Elements of Political Economy, vol. II, pp. 395-396. 


\section{Chapter VII}

Henry Carey, Nature, and the Destiny of Man

Just as the savage must wrestle with Nature to satisfy his wants, to maintain and reproduce so must civilized men, and he must do so in all social formations and under all possible modes of production. With this development this realm of physical necessity expands as a result of his wants; but, at the same time, the forces of production which satisfy these wants also increase. Freedom in this field can only consist in socialized man, the associated producers, rationally regulating their interchange with Nature, bringing it under the common control, instead of being ruled by the blind forces of Nature; and achieving this with the least expenditure of energy and under conditions most favorable to, and worthy of, their human nature. ${ }^{1}$

Henry Carey united protectionist ideas into a coherent ideology. He was the most important thinker of American protectionism. More than any other antebellum economists, he drove protectionist thought to its furthest logical conclusion. Carey borrowed from a variety of antebellum intellectual and cultural sources to construct what stands as the most complete repudiation of British classicism. By highlighting American exceptionalism, free-labor ideology, nationalism, and an optimistic vision of the natural economic order, Carey penetrated the paradigmatic foundations of free-trade doctrine and presented an economic narrative that was radically different from the British model. His political economy was based on a whiggish interpretation of the American economic experience. It reflected important antebellum beliefs of America's economic destiny. Carey's works epitomized not only the protectionist brand of American political economy, but in many ways his writings encapsulated the most authentic expression of the antebellum economic mind.

Born in Philadelphia in 1793, Carey was the eldest son of Mathew Carey. His interests in political economy were sparked as a boy perusing the commercial tracts that passed through his father's publishing house. At twenty-eight he succeeded his father as

\footnotetext{
${ }^{1}$ Karl Marx, Capital (1894; reprint, Oxford, 1995), p. 470.
} 
a partner in the firm. In 1834 Carey retired from the printing business to launch a career as a public intellectual. He enjoyed a moderate celebrity during his time, writing numerous books and dozens of articles. In protectionist circles Carey was an icon. His economic ideas were widely circulated. Carey's works were translated into several languages. And when Lincoln ascended to the White House Carey became one of the President's chief economic advisors. ${ }^{2}$

Carey's intellectual development in some ways was analogous to the historical evolution of antebellum political economy. Early in his career Carey professed the principles of Smithian laissez-faire. In 1840 he completed a three-volume work illustrating a commitment to free-trade maxims. He admired Smith deeply, and extolled him as "the great father of political economy."3 But as Carey matured, he distanced his thought from the works of Malthus and Ricardo. "Need we then wonder," Carey wrote, "that by that school the field of economical science has recently been so reduced in its proportions that it is now limited to the consideration of the mere acts of buying cheaply and selling dearly, having thus become a sort of shopkeeping science." ${ }^{\text {If Smith }}$ were alive in the mid-nineteenth century, Carey posited, the Scotsman would oppose the very science attributed to him. ${ }^{5}$ The decisive moment in Carey's intellectual life came one morning in

\footnotetext{
${ }^{2}$ For works on Carey see Andrew Dawson, "Reassessing Henry Carey (1793-1879): The Problems of Writing Political Economy in Nineteenth-Century America," Journal of American Studies (December, 2000); Rodney J. Morrison, "Henry C. Carey and American Economic Development," Transactions of the American Philosophical Society, vol. 76, part 3 (Philadelphia, 1986); A.D.H. Kaplan, Henry Carey: A Study in American Economic Thought (Baltimore, 1931); George Winston Smith, Henry C. Carey and American Sectional Conflict (Albuquerque, N.M., 1931).

${ }^{3}$ Henry Carey, The Unity of Law; as Exhibited in the Relations of Physical, Social, Mental and Moral Science (1872; reprint, New York, 1967),p. 282.

${ }^{4}$ Henry Carey, “Our Resources” (1865), Miscellaneous Works of Henry Carey (1883; reprint, New York, 1967), vol. II, pp. 22-23.

${ }^{5}$ Carey, The Unity of Law, p. 30.
} 
the 1840 s when, as if struck by an epiphany, he "jumped out of bed, and dressing myself, was a protectionist from that hour." 6

Indications of Carey's liberal apostasy were communicated in his 1835 Essay on the Rate of Wages. Like most Americans, he did not find evidence of Ricardo's conclusions in prevailing domestic conditions. For Carey, American industrialization would follow an alternative course from the British model. Carey's rebuke of Ricardian theories of distribution hinged on a belief in the exceptional circumstances enjoyed by American labor. American workers were eager to contribute to the nation's unprecedented productivity precisely because they were justly rewarded with a sizable share of profits. "No people," Carey found, "ever had stronger inducements, so none ever pursued their avocations with more earnestness." ${ }^{7}$ Contrary to Ricardo, higher wages did not take from profits. Neither did wages come from a fixed wages-fund. Instead, wages drew from a rapidly increasing pool of profits and capital. "Where wages are highest," Carey wrote, "there capital increases most rapidly." ${ }^{8}$ Advances in manufacturing technologies promised increasing returns. Ricardo's so-called Iron Law of Wages and Law of Diminishing Returns were not evident in the American economy. Indeed, Carey found that the value of labor increased over time, or put another way, became more effective at exploiting capital. Therefore, capitalists and workers enjoyed higher yields and greater access to the comforts of life.

Carey's theory of wages reflected protectionist claims that America lacked a permanent class structure. By the 1850 s protectionists took an increasingly whiggish tone in their interpretations of American industrialization. This was a strikingly different interpretation of economic development from the Ricardian model. Carey celebrated free-labor mythology and

\footnotetext{
${ }^{6}$ Quote found in Malcolm Rogers Eiselen, The Rise of Pennsylvania Protectionism (New York, 1974), p. 176.

${ }^{7}$ Henry Carey, Essay on the Rate of Wages (1835; reprint, New York, 1965),pp. 145, 23, 32, 83, 88, 90.

${ }^{8}$ Ibid., p. 23.
} 
touted social mobility as hallmarks of the American economic experience. His wage doctrine also helped further the divided between protectionism and classical doctrine over theories of rent and profit. Ricardo maintained that as population and capital increased humanity moved to cultivate less fertile lands, dwindling returns on capital and labor. Carey rejected this historical narrative. He criticized Ricardo for presuming that the earliest settlers cultivated the most fecund lands. Instead, Carey argued that the most fertile lands were rarely the first to be tilled. Early settlements, often times selected for their strategic positioning, required little clearing, seldom occupied a region's most alluvial soils, and generally afforded a small return to labor. These settlements were typically founded during the primitive stages of civilization and were therefore ploughed using experimental tools and archaic agronomics. Only after a community felt secure did men venture out, from the "hills and mountains toward the rich lands at their feet: and everywhere, with the growth of number, penetrating the earth to reach the lower soils." ${ }^{9}$ With each passing generation more fertile lands were discovered, cultivated with more effective implements that facilitated larger returns to labor and capital.

Carey's interpretation of migratory patterns pointed to human agency as the determining factor in rents. Carey's theory of rent reflected the prevailing optimism Americans harbored over their ability to control the economic fate of the nation. He rejected the Ricardian assumption that rent was dependent upon the "original and indestructible powers of the soil." For Carey, agricultural yields were controlled by man's imposition of their labor and capital on nature. "Labor and skill have been applied, and the difficulty is removed, a consequence of which is that they are becoming very valuable, although their fertility is no greater than before." ${ }^{10}$ The development of technology and the ability of man to employ its labor more effectively meant that the greatest returns lay in the distant future. Carey infused his theory of rent with a buoyant

\footnotetext{
${ }^{9}$ Henry Carey, The Past, the Present, \& the Future (1847; reprint, New York, 1967), p. 48.

${ }^{10}$ Henry Carey, Principles of Political Economy (1837; reprint, New York, 1965), vol. I, p. 46.
} 
optimism. "We possess no means of measuring the extent of the powers of the earth. It produces now vastly more than it did half a century since, and the close of the present century will see it rendered greatly more productive than at present."11 Each successive generation builds upon the improvements of the previous, promising humanity greater command over natural resources.

Carey's confidence relayed antebellum attitudes on the ability of Americans to mold the continent to their liking and shape their nation's economic destiny. The optimism he expressed in his theories of distribution was radically different from the ominous features of classical doctrine. Increasing returns were accelerated or slowed depending upon society's ability to, according to Carey, "combine their exertions for the increase of production and for mutual production, thus rendering their labor more productive, and promoting the further increase of production." ${ }^{12}$ Heightened production rates were precipitated by the inclination in all men to gravitate toward one another and form associations that pooled together human energies. Human association was inherent to the march of civilization, engendering a greater social diversity of productive powers and a more refined division of labor. The latter enlarged what Carey referred to as concentrated "motion" or "local action."13

With the help of his disciple E. Peschine Smith, Carey's theory of association was formulated into an economic law of human society based on organic chemistry and ecological studies. ${ }^{14}$ In the antebellum literature, Smith and Carey helped establish a new approach to economic inquiry. Carey undermined classical conventions by presenting an alternative

\footnotetext{
${ }^{11}$ Ibid., p. 130.

${ }^{12}$ Henry Carey, Principles of Political Economy, (1840; reprint, New York, 1965), vol. III, p. 252.

${ }^{13}$ Henry Carey, Principles of Social Science, (1858; reprint, New York, 1963), vol. I, p. 292.

${ }^{14}$ E. Peschine Smith studied at Columbia and Harvard, was professor of mathematics at Rochester, served the U.S. government as commissioner of immigration, and in 1871 began a five-year stint as special advisor in Japan. His principal treatise The Manual of Political Economy was published in $1853.10 \%$ of Smith's work is quoted verbatim in Carey's Principles of Social Science. Many of Carey's ideas are given emphasis in Smith's work.
} 
understanding of the natural economic order. Extracting the nutritional values from land, digesting those nutrients, and recycling residual refuse back into the ecosystem was not only the natural sequence, but a strategy that promised unprecedented returns. Recycling nature's store was for Carey fundamental to civilization's progress. The intensification of association, or, the increase in exchanges generated by bringing together within a restricted area the forces of production and consumption advanced the accumulation of wealth. "The more distant the loom and the anvil, the more labor and manure are wasted...The nearer the place of exchange, the less labor are wasted on the road, and the more uninterruptedly is labor applied..." ${ }^{15}$ When producers trade goods in distant markets they forfeit valuable residuals that would have otherwise been credited to a community's local resources. In short, distance precluded regeneration, for "the manure cannot be returned to the land." 16

For this reason Carey chided merchant trade for inhibiting the process of association and thus slowing the accumulation of wealth. His theory of association struck at Ricardian notions of comparative advantage and complimented the protectionist home-market argument. Carey also illustrated an intellectual debt to Adam Smith. The Scotsman had noted the efficiencies of domestic markets in his Wealth of Nations. ${ }^{17}$ International trade widened the space between producers and consumers, limiting the extent of human association and exchange within a community. On various occasions Carey backed the abolition of long-distance merchant trade. ${ }^{18}$ The "converters and exchangers" of the world reaped what the farmer sowed, stole from

\footnotetext{
${ }^{15}$ Henry Carey, The Harmony of Interests, Agricultural, Manufacturing, and Commercial (1851; reprint, New York, 1967), p. 49.

${ }^{16}$ Carey, Principles of Social Science, vol. I, p. 367.

${ }^{17}$ Carey, Principles of Social Science, vol. I, p. 294. For a recent discussion of protectionist use of Smith's Wealth of Nations to advance the home-market argument, see Nicholas Onuf and Peter Onur, Nations, Markets, and War: Modern History and the American Civil War (Charlottesville, VA, 2006), pp. 264-266. Smith also expressed at various points disdain for merchants.
} 
labor's wage, and imposed an "exhausted tax" on consumers. British laissez-faire led to what Carey called the "centralization" of the forces of production and consumption. ${ }^{19}$ In other words, by restricting the diversity of national production a population became more specialized in certain industries, encouraging dependence on foreign trade and preventing localized action from enhancing the regenerative powers of a community. By widening the gap between producers and consumers national economies in general and labor especially, becomes "more completely an instrument of trade." ${ }^{20}$ A protective tariff was the most efficient measure at blocking the destructive tendencies of international trade. Tariffs helped establish a national economy with regionalized divisions of labor, secured for workers and capitalists higher returns, and stalled domestic migration to western lands. Most importantly for Carey, tariffs liberated America from the fetters of foreign markets. ${ }^{21}$

Although Carey claimed his theory of association was a natural economic law, like most protectionists his political economy rested on an understanding of economic development that was peculiar to antebellum America. The association theory expressed contemporary cultural perceptions of how Americans might employ technology against the natural environment. During the antebellum era industrial technologies were thought by many the harbingers of the modern age. ${ }^{22}$ The ultimate expressions of human reason, machines took on a progressive metaphysical

\footnotetext{
${ }^{18}$ Carey, Harmony of Interests, pp. 101, 136, 147, 198; Carey, Principles of Social Science, vol. I, pp. 186, 211, 263, 377, 369-370.

${ }^{19}$ Carey, Principles of Social Science, vol. I, p. 213.

${ }^{20}$ Carey, Harmony of Interests, p. 83; Henry Carey, The Principles of Social Science (1858; reprint, New York, 1867), vol. II, p. 40.

${ }^{21}$ Henry Carey, "Reconstruction: Industrial, Financial, and Political" (1867), Miscellaneous Works of Henry Carey, vol. II, p. 9

${ }^{22}$ David Nye, American Technological Sublime (Cambridge, MA, 1994), pp. 56-60; Leo Marx, The Machine in the Garden: Technology and the Pastoral Ideal in America (Oxford, 2000), pp. 192-214; John Kasson, Civilizing the Machine: Technology and Republican Values in America, 1776-1900 (New York,
} 
idealism. Machinery was the "great instrument of civilization," empowering Americans in their historical quest to tame nature and bring the earth's resources under their control. ${ }^{23}$

For Carey the earth was a passive agent; its wealth depended upon man's ability to combine his powers of production and consumption. The rate at which these powers were coordinated determined society's technological potency, which in turn established the American capacity to mine from nature its wealth. "The earth is a great machine, given to man to be fashioned to his purpose. The more he fashions it, the better it feeds him, because each step is but preparatory to a new one more productive than the last; requiring less labor and yielding larger returns...He is obtaining a daily increased power of the various treasures of the earth." ${ }^{24}$ There was no way to tell how much from nature's store labor and capital could extract. In the distant future, Carey conjectured, Americans will employ technologies to subjugate the unknown powers of the earth, "powers so wonderfully great that it would be absurd, with our present limited knowledge, to attempt a definition of their extent." 25

Carey's ideology of optimism contrasted starkly with the laissez-faire tradition. It was based largely on the belief that Americans had at their disposal the power to direct nature's course. Contrary to classical political economy, the natural economic order was not beyond man's control. Neither was nature something to fear. Rather nature's immeasurable treasures were open to man's exploit. "To the power of the earth...there are no limits. Her treasury overflows with the raw materials of food and clothing, and all she asks is that he will come and take them." ${ }^{26}$ Malthus and Ricardo, Carey argued, failed to comprehend man's ability to wring

1982), pp. 41-47, 111-114; Daniel Boorstin, The Republic of Technology: Reflections on Our Future Community (New York, 1978), pp. 26, 42-48

${ }^{23}$ Carey, Principles of Social Science, vol. I, p. 137; Carey, Harmony of Interests, p. 78.

${ }^{24}$ Carey, The Past, the Present, \& the Future, p. 95.

${ }^{25}$ Ibid., p. 91. 
from nature what he desires. British classicism described man as a "mere brute animal." "The real man," Carey declared, "the being made in the image of his creator, fitted for becoming master of nature and an example worthy to be followed by those around him."27 In an explicit rebuke of Malthus, Carey figured "twice, or thrice, ten, or twenty, or fifty times the population could be supported, even with our present agricultural knowledge...we cannot hesitate to admit that the productive power of land exists in measureless quantity." ${ }^{28}$ The English economist had made the profound mistake of underestimating the powers of man over nature. Malthus and Ricardo were blind to the "breath of the spirit" in man. ${ }^{29}$ "Mr. Ricardo makes him," Carey wrote, "throughout, the victim of a sad necessity that precludes the existence of hope. He is destitute of power over the land, or over himself, and he can have no confidence in the future. The machine he uses must deteriorate." ${ }^{30}$

Carey's brand of protectionism stretched beyond economic analysis toward a theory on human evolution. His inflated assessments of man's position vis-à-vis nature were central to his economic philosophy and an explicit rebuke of British classicism. Classical political economy, Carey found, "teaches, that all the evils of society are the result of one great force constantly impelling man in a wrong direction-increasing the number of mouths, as the machine by help of which, alone, they can be fed, diminishes." ${ }^{31}$ Beginning with Smith, laissez-faire posited a belief in a natural order governed by laws that, if they were even discernable to man's fickle understanding, exercised absolute command over the course of human existence. According to

\footnotetext{
${ }^{26}$ Carey, Principles of Social Science, vol. II, p. 38.

${ }^{27}$ Carey, The Unity of Law, pp. 61, vii.

${ }^{28}$ Carey, Principles of Political Economy, vol. I, p. 130.

${ }^{29}$ Carey, The Unity of Law, p. 62.

${ }^{30}$ Carey, The Past, the Present, \& the Future, p. 248.

${ }^{31}$ Carey, Principles of Political Economy, vol. III, p. 279.
} 
the British authorities, "the power of nature over man [was] steadily increasing," Carey wrote, with man becoming "more and more her slave." ${ }^{32}$

Carey transformed the economic relationship between man and nature. Nature and humanity were not aligned so that the order established by Providence devolved toward selfdestruction, leaving men weak and destitute. "The great Architect of the universe was no blunderer," Carey posited, "can it be, then, that after having given to man all the faculties required assuming the mastery of nature, it has been a part of his design, to subject him to absolute and irreversible laws, in virtue of which he must inevitably become nature's slave?" ${ }^{33}$ For Carey man reigned over nature. Her order was understood, its once troubling mystical and subliminal powers made "to serve the purpose of man-and with his coming we find the important difference that whereas all other animals were bound to continue forever the slaves of nature, he alone was gifted with the faculties required for enabling him to become her master, and to make her do his work." ${ }^{34}$ While Malthus and Ricardo looked to "the ultimate enslavement of man by nature," Carey reversed the sequence. ${ }^{35}$ He recounted a sweeping historical narrative of the epic struggle between the physical powers of the earth and the intellectual powers of humanity. "Matter and mind were to be brought face to face with each other, contending for mastery of the world; the former armed with powers so prodigious that words scarcely suffice for their enumeration and description; the latter at first so weak as to be deficient in many of the qualities by means of which even the lowest animals had been fitted for self-preservation." Nature's colossus bore down heavily on man's frail and feeble intellect, bringing distress and privation to the early human condition. With time civilization's march began, and "step by step, mind is seen gaining

\footnotetext{
${ }^{32}$ Ibid., vol. III, pp. 134, 147.

${ }^{33}$ Henry Carey, Principles of Social Science (1859; reprint, New York, 1963), vol. III, p. 265.

${ }^{34}$ Ibid., vol. I, p. 71.

${ }^{35}$ Ibid., vol. I, p. 418.
} 
on its opponent, seizing his outworks and on the instant turning upon him the captured gains, each forward movement proving thus by simple preparation for a new and greater one." ${ }^{36}$

In Carey's dialogue with laissez-faire the destiny of man held an inestimable improvement in the human condition. The industrial revolution was the catalyst in Carey's narrative. Industrialization accelerated humanity's exploitation of nature, "constantly battering at her gates, and overthrowing her walls." ${ }^{37}$ History was the story of man's progress. Carey's work is very much a solicitation for political economy to recognize man's newly acquired dominance over nature. Americans' ability to employ technology over nature was an increasingly popular concept by the end of the antebellum period. ${ }^{38}$ "At every step there is an increased consciousness in man of the existence of power to improve his condition, producing increased desire of improvement. Desire produces determination, and determination creates power." ${ }^{39}$ A more effective deployment of industrial technologies left nature subject to man's will. "With each addition thereto, he finds less resistance to his further efforts; and hence it is, that each successive discovery proves to be but the precursor of new and greater ones." "Each successive year" Carey continued, "thus augments the power of man, and with every new discovery utility is given to forces that now are being wasted. The more they are being utilized-the more nature is made to labor in man's service- - the less is the quantity of human effort required for the reproduction." 40

Market forces and the natural economic laws that Smith, Malthus and Ricardo had argued humanity was powerless over were cast in a new light by Carey. The market could be controlled,

\footnotetext{
${ }^{36}$ Carey, The Unity of Law, pp. 158-159.

${ }^{37}$ Carey, Principles of Social Science, vol. III, p. 332.

${ }^{38}$ For Americans' understanding of the relationship between technology and nature see William Cronon, Nature's Metropolis: Chicago and the Great West (New York, 1991); Leo Marx, The Machine and the Garden: Technology and the Pastoral Ideal in America (Oxford, 2000).

${ }^{39}$ Carey, The Past, the Present, \& the Future, p. 54.

${ }^{40}$ Henry Carey, "Money: A Lecture Delivered Before the New York Geographical and Statistical Society" (1857), Miscellaneous Works of Henry Carey (1883; reprint, New York, 1967), vol. I, p. 11.
} 
the natural order fashioned to the benefit of man, and nature's forces brought under man's dominion. The pessimism of the classical school seemed if not entirely unwarranted, then certainly excessive. Carey premised his political economy on the economics of affluence. He offered an alternative to the British political economy of poverty. "The whole English politicoeconomical system," he maintained, was "invented for the purpose of accounting for the poverty and wretchedness which are its results." ${ }^{41}$

This belief contributed to calls for a distinctly American political economy. A "really American policy," Carey wrote just after the Civil War. ${ }^{42}$ The success of protectionist ideology in the antebellum and post-Civil War periods indicates that American economic culture was primed for a paradigmatic alternative to British laissez-faire. For an American system of economic thought protectionists believed the native mind needed to turn inward. Carey's protectionism reflected an understanding that the United States advanced toward unchartered economic territories of unprecedented material prosperity. The American experience required a nuanced intellectual framework, one radically different from Old World traditions, and one that reflected the economics of the American conscience.

Although Carey's brand of protectionism was in the main an expression of Northern economic ambitions, it drew from an assortment of cultural and intellectual traditions that permeated much of American intellectual and economic history. Under Carey, protectionism combined various strains of the American economic mind into a single ideology. It made American exceptionalism the central piece of an overtly optimistic political economy that rebuked the dismal forecasts of Malthus and Ricardo. In doing so, protecitonists helped relieve domestic anxieties over the negative social consequences of industrialization. Protectionism promised that the tariff would serve as a practical measure to soften labor's transition into the

\footnotetext{
${ }^{41}$ Carey, Harmony of Interests, p. 64.

${ }^{42}$ Henry Carey, "Our Future," Miscellaneous Works of Henry Carey, vol. I, pp. 6-7.
} 
industrial age. In no way did the protectionists wish to overturn free-market institutions in the domestic economy. Instead, they challenged the agrarian disposition of the antebellum free-trade movement by formulating a political economy aimed at hastening the proliferation of industrial capitalism in domestic markets. The protectionists also relied on an understanding of international relations that legitimated contemporary concerns of foreign aggression. Finally, the protectionists constructed an economic ideology unequivocally opposed to the extremism of Southern reactionaries. By fusing these components into a unified school of economic thought the protectionists believed their ideology met American aspirations for industrialization, and political and economic independence. 


\section{Chapter VIII}

Liberalism, Republicanism, and Finance

Had a committee of clever men been selected to devise means by which the public might be tempted to engage in all manner of absurd projects, and be most easily duped and swindled, we do not know that they could have hit upon anything half so likely to effect their object as the existing American banking system. It has no one redeeming quality about it, but is from beginning to end a compound of quackery and imposture. ${ }^{1}$

Henry Carey cemented the divisions between American laissez-faire and protectionism.

The distinctions in antebellum discussions of trade did not, however, extend to every aspect of the economy. When it came to finance and financial markets, Americans entertained a variety of perspectives, few of which conform to the conventional understanding of economics and ideology. Most expressed feelings of skepticism and suspicion, but the opposition to finance took on several shades of theoretical nuance. Critics described financial institutions as obscure, shadowy and not quite legitimate, a position that even the most dedicated pro-market economist shared. Indeed, the opposition to finance sprung typically from the most ardent supporters of free-market economics. Likewise, advocates of finance encouraged state intervention. In short, Americans constructed as dynamic a discourse on finance as they had on industry and trade. Opponents and supporters drew ambiguous ideological lines unique to the antebellum discourse. In both cases, the literature lacked a definitive consensus, showcasing the general discord that marked antebellum political economy.

Historians of antebellum finance tend to simplify the complexities of the financial discourse. One interpretation posits a neat division between two rival camps. These historians define the differences as a kind of class warfare, with those opposed to the expansion of finance pitted against an enterprising elite bent on modernizing financial institutions at the expense of the common man. According to this interpretation, lower class urban workers and farmers joined

\footnotetext{
${ }^{1}$ J.R. McCulloch, A Dictionary, Practical, Theoretical, and Historical, of Commerce and Commercial Navigation (Philadelphia, 1852), vol. II, p. 778.
} 
forces to wage war on financial capitalism; Andrew Jackson led them. The resistance crystallized in 1832 with Jackson's veto of the Bank of the United States. The president's use of class rhetoric lends credence to the class-conflict interpretation. In his bank veto message to the Senate, Jackson lamented "that the rich and the powerful too often bend the acts of government to their selfish purposes...make the rich richer and the potent more powerful." ${ }^{2}$ Suspicions of an aristocracy of banking marauders led King Mob, according to one historian, to whip up into a frenzy "a democratic challenge to bourgeois/middle class hegemony that is unparalleled in presidential annals" and "politicize popular resistance to capitalist transformation by mobilizing patriarchal democracy against the money power." ${ }^{3}$ In short, opposition to finance precipitated a wider struggle against capitalism.

Other historians have found less class conflict in Jacksonian America. What Jackson wanted, they argue, was more not fewer banks. Jackson exemplified an incipient bred of bourgeois individualism intent on democratizing capitalism, liberating markets, and facilitating access to cheap credit. All Americans desired a thriving financial sector; they did not organize against it. An authority on this interpretation, Bray Hammond, writes, "The millionaires created by the so-called Jacksonian revolution of 'agrarians' against 'capitalists'—of the democracy against the money power-were richer than those they dispossessed, they were more numerous, they were quite as ruthless; and laissez faire, after destroying the monopolies and vested rights

\footnotetext{
${ }^{2}$ Andrew Jackson, “Bank Veto," July 10, 1832, Francis Newton Thorpe, ed., The Statesmanship of Andrew Jackson as Told in His Writings and Speeches (New York, 1909), pp. 174-175.

${ }^{3}$ Charles Sellers, The Market Revolution: Jacksonian America, 1815-1846 (New York, 1991), p. 313; Arthur Schlesinger, The Age of Jackson (Boston, 1946); Harry L. Watson, Liberty and Power: The Politics of Jacksonian America (New York, 2006); Harry L. Watson, Jacksonian Politics and Community Conflict: The Emergence of the Second Party System in Cumberland County, North Carolina (Baton Rouge, LA, 1981); Sean Wilentz, The Rise of American Democracy: Jefferson to Lincoln (New York, 2005); John Ashworth, 'Agrarians' and 'Aristocrats': Party Political Ideology in the United States, 1837-1846 (Cambridge, 1987); John Ashworth, Slavery, Capitalism, and Politics in the Antebellum Republic, Vol. I: Commerce and Compromise, 1820-1850 (Cambridge, 1995), especially pp. 289-315.
} 
the Jacksonians decried, produced far greater ones." ${ }^{4}$ Jackson's veto message, according to Richard Hofstadter, "is not the philosophy of a radical leveling movement... What is demanded is only the classic bourgeois ideal... This is the philosophy of a rising middle class; its aim is not to throttle but to liberate business, to open every possible pathway for the creative enterprise of the people."

This chapter argues against both of these interpretations. It introduces a middle variant expressed by most antebellum political economists. Though liberal in most aspects of their economic philosophy, these moderates opposed financial capitalism (even while they celebrated markets and capitalism in all other aspects). Most possessed not an anti-capitalist nerve in their body, but all dreaded the moral, social, political, and economic consequences of financial institutions. Indeed, opposition to finance was testament to an economist's devotion to free markets. The opposition literature also drew inspiration from a classical republican tradition whose origins stretched to Augustan England. ${ }^{6}$ Antebellum critics of finance fused laissez-faire and classical republicanism to form a financial opposition ideology unique to America.

The seminal event in antebellum finance was Jackson's veto of the Bank of the United States. "I do not dislike your Bank any more than all banks," Jackson wrote BUS president Nicholas Biddle in 1829, "but ever since I read the history of the South Sea Bubble I have been

\footnotetext{
${ }^{4}$ Bray Hammond, Banks and Politics in America: From the Revolution to the Civil War (Princeton, 1967), pp. 345-346; Joseph Dorfman, The Economic Mind in American Civilization, 1606-1865 (New York, 1946), vol. II, chapter XXIV; Dorfman, "The Jackson Wage-Earner Thesis," The American Historical Review (January, 1949), pp. 304-306; Daniel Walker Howe, What Hath God Wrought: The Transformation of America, 1815-1848 (New York, 2007), pp. 380-393.

${ }^{5}$ Richard Hofstadter, The American Political Tradition and the Men Who Made It (New York, 1974), p. 78.

${ }^{6}$ Stuart Banner, Anglo-American Securities Regulation: Cultural and Political Roots, 1690-1860 (Cambridge, 1998); Major Wilson, "The 'Country' versus the 'Court': A Republican Consensus and Party Debate in the Bank War," Journal of the Early Republic (Winter, 1995).
} 
afraid of banks." ${ }^{7}$ Jackson was referring to England's first major financial crisis in the early eighteenth century. ${ }^{8}$ The South Sea Bubble of 1720 incited a republican style of economic thought that had at its center opposition to finance. ${ }^{9}$ Jackson's republican political economy was likely informed by the English protest writings of John Trenchard and Thomas Gordon. From 1720 until 1724 they penned essays for the London Journal later published as Cato's Letters. Trenchard and Gordon were the principal fund from which most Americans learned of English opposition thought. ${ }^{10}$ Whether Americans realized it or not, they repeated the same arguments and used almost identical rhetorical strategies as England's classical republicans. The migration of English opposition thought to America points to a fairly consistent attempt at the formulation of a decidedly anti-finance strain in republican political economy. ${ }^{11}$

\footnotetext{
${ }^{7}$ Jackson to Nicholas Biddle, November, 1829, Charles McGrane, ed., The Correspondences of Nicholas Biddle Dealing with National Affairs, 1807-1844 (New York, 1919), p. 93.

${ }^{8}$ On the importance of the South Sea Bubble in Anglo-American economic history see Charles P. Kindleberger, Manias, Panics, and Crashes: A History of Financial Crises (New York, 2000), p. 122; John Carswell, The South Sea Bubble (London, 1960), pp. 271-272; Virginia Cowles, The Great Swindle: The Story of the South Sea Bubble (New York, 1960), p. 40; Peter Garber, Famous First Bubbles: The Fundamentals of Early Manias (Cambridge, MA, 2000), pp. 11-12, 115; Richard Dale, The First Crash: Lessons From the South Sea Bubble (Princeton, 2004), p.102; Bruce Carruthers, City of Capital: Politics and Markets in the English Financial Revolution (Princeton, 1996), pp. 83-85; Malcolm Balen, A Very English Deceit: The Secret History of the South Sea Bubble and the First Great Financial Scandal (London, 2003); Larry Neal, The Rise of Financial Capitalism: International Markets in the Age of Reason (Cambridge, 1990); Margaret Patterson and David Reiffen, "The Effects of the Bubble Act on the Market for Joint Stock Shares," The Journal of Economic History (vol. 50, issue 1, 1990); Armand Du Bois, The English Business Company After the Bubble Act, 1720-1800 (New York, 1971).

${ }^{9}$ J.G.A. Pocock, The Machiavellian Moment: Florentine Political Thought and the Atlantic Republican Tradition (Princeton, 1975), chapters 11-15; J.G.A. Pocock, "Virtue and Commerce in the Eighteenth Century," The Journal of Interdisciplinary History (Summer, 1972); J.G.A. Pocock, ed., The Political Works of James Harrington (Cambridge, 1977), p. 138

${ }^{10}$ On the popularity of Gordon and Trenchard in American literature see Elizabeth Cook, Literary Influences in Colonial Newspapers, 1704-1750 (Port Washington, N.Y., 1966), p. 3; Bernard Bailyn, The Ideological Origins of the American Revolution (Cambridge, MA,1967), p. 44; Henry F. May, The Enlightenment in America (Oxford, 1976), pp. 39-41; Caroline Robbins, The Eighteenth-Century Commonwealth Man: Studies in the Transmission, Development and Circumstances of English Liberal Thought from the Restoration of Charles II until the War with the Thirteen Colonies (Cambridge, MA, 1961), p. 385; Bernard Cottret, ed., Bolingbroke's Political Writings: The Conservative Enlightenment (New York, 1997), pp. 1, 10.
} 
In America, republican opposition to finance first surfaced in response to Alexander Hamilton's program for financial modernization. Presented in the early 1790s, Hamilton's plan included the assumption of states' debts, discrimination in the repayment of revolutionary debt, increases in domestic excise and tariffs, the funding of the national debt, and the establishment of a national bank. ${ }^{12}$ He declared credit the "invigorating principle."13 And Hamilton's brainchild, a national bank, was touted as "an institution of primary importance to the prosperous administration of the finances" that encouraged "the augmentation of active or productive capital" and provided a boom to the national economy. ${ }^{14}$ His scheme was based in part on the controversial point that "public debts are public blessings." ${ }^{15}$ In his view, the modernization of

${ }^{11}$ Bailyn, The Ideological Origins of the American Revolution; Gordon Wood, The Creation of the American Republic (New York, 1969); Lance Banning, The Jeffersonian Persuasion: Evolution of a Party Ideology (Ithaca, 1978); Drew McCoy, The Elusive Republic: Political Economy in Jeffersonian America (Chapel Hill, 1980); Sean Wilentz, Chants Democratic: New York City and the Rise of the American Working Class, 1788-1850 (New York, 1984); Banner, Anglo-American Securities Regulation; Pocock, The Machiavellian Moment, p. 423.

${ }^{12}$ The synopsis of Hamiltonian finance comes from Peter McNamara, Political Economy and Statesmanship: Smith, Hamilton, and the Foundation of the Commercial Republic (DeKalb, IL, 1998), pp. 113-127; Stanley Elkins and Eric McKitrick, The Age of Federalism: The Early American Republic, 17881800 (Oxford, 1993), pp. 110-144; Louis Hacker, Alexander Hamilton in the American Tradition (New York, 1957), pp. 128-186; James Roger Sharp, American Politics in the Early Republic: The New Nation in Crisis (Hartford, CT, 1995), pp. 34-42; E. James Ferguson, The Power of the Purse: A History of American Public Finance, 1776-1790 (Chapel Hill, NC, 1961), pp. 337-343; Gerald Stourzh, Alexander Hamilton and the Idea of Republican Government (Stanford, 1970).

${ }^{13}$ Alexander Hamilton, Public Credit, January 16, 1795, Henry Cabot Lodge, ed., The Works of Alexander Hamilton (New York, 1904), vol. III, p. 294. See also Alexander Hamilton, First Report on Public Credit, January 14, 1790, Henry Cabot Lodge, ed., The Works of Alexander Hamilton (New York, 1904), vol. II, p. 232-233, 295-298.

${ }^{14}$ Alexander Hamilton, National Bank, Dec. 14, 1790, The Works of Alexander Hamilton, vol. III, pp. 388390.

${ }^{15}$ The "public debts are public blessings" passage reads in its entirety as follows: "A national debt, if it is not excessive, will be to us a national blessing. It will be a powerful cement of our union. It will also create a necessity for keeping up taxation, to a degree which, without being oppressive, will be a spurn to industry, remote as we are from Europe, and shall be from danger." Hamilton to Robert Morris, April 30, 1781, The Works of Alexander Hamilton, vol. III, p. 387. It seems Hamilton meant a national debt justified tariffs to provide a spurn to domestic manufactures. See John Steel Gordon's chapter "The Hamiltonian Miracle," in Hamilton's Blessing: The Extraordinary Life and Times of Our National Debt (New York, 1998), for Hamilton's financial plans. 
domestic finance would improve America's credit rating. ${ }^{16}$ Trust in the nation's financial institutions was, according to Hamilton, "the palladium of public safety." ${ }^{17}$ By attracting the interests of financiers, the republic's strongest economic supporters would come from the financial sector. "To promote the increasing respectability of the American name," Hamilton wrote, "to cement more closely the union of the states...[and] to add to their security against foreign attack." 18

The sharpest critique of Hamilton's agenda came from John Taylor of Caroline. Taylor was born in 1753 into the political elite of Virginia's gentry. A distant cousin of James Madison, a confidant of Thomas Jefferson, and son-in-law to a signee of the Declaration of Independence, Taylor served in the Virginia House of Delegates and in the U.S. Senate. He authored a number of political, social, and economic tracts that exemplified Southern republican opposition to the expansion of finance. ${ }^{19}$ Taylor died in Port Royal, Virginia in 1824, not far from where Fitzhugh took up residence five years later. Taylor established a pattern of oppositional thought that anticipated the anti-finance movement of the later-antebellum period. Thus, he embraced the principles of laissez-faire economics, at the same time, he repudiated financial institutions.

Taylor's opposition to finance rested on a laissez-faire-republican critique of the relationship between financial institutions and legislatures. "By incorporations, great bodies politic, whole parties, and entire states, may be degraded into clientage, and bribed to obedience;

\footnotetext{
${ }^{16}$ On Hamilton's plan to tie the interest of moneyed men to the public credit, see Hamilton to Robert Morris, 1780, The Works of Alexander Hamilton, vol. III, p. 338; Hamilton to Robert Morris, April 30, 1781, The Works of Alexander Hamilton, vol. III, p. 360. For Hamilton's defense of the assumption of the states debt, see Alexander Hamilton, First Report on the Public Credit, The Works of Alexander Hamilton, vol. II, pp. 227, 228, 244, and especially pp. 246-248.

${ }^{17}$ Hamilton to George Washington, August 18, 1792, The Works of Alexander Hamilton, vol. II, p. 426.

${ }^{18}$ Alexander Hamilton, Public Credit January 14, 1790, The Works of Alexander Hamilton, vol. II, p. 232.

${ }^{19}$ Garrett Ward Sheldon and C. William Hill, The Liberal Republicanism of John Taylor of Caroline (Madison, NJ, 2008); Eugene Tenbroeck Mudge, The Social Philosophy of John Taylor of Caroline: A Study in Jeffersonian Democracy (New York, 1939); Robert Shallhope, John Taylor of Caroline: Pastoral Republican (Columbia, SC, 1980).
} 
and legislators themselves may participate in every bonus they bestow." ${ }^{20}$ And like most early antebellum republican opponents of finance, Taylor incorporated a pastoral idealism into his critique of financial institutions. Combining laissez-faire with agrarianism was common in the antebellum movement against finance. The expansion of finance hastened "a decay and impoverishment both in mind and fortune of the landed gentry, and an exchange of that honest, virtuous, patriotic and bold class of men, for an order of stock-jobbers in loans, banks, manufactories... and an infinite number of inferior tricks to get money, calculated to instill opposite principles." ${ }^{21}$ In republican political economy, agriculture provided the source of wealth; therefore, the prosperity of financiers came at the expense of farmers. "Hence we see capital flying from the fields," Taylor wrote, "to the legal monopolies, banking and manufacturing. The laws have established a thousand modes by which capital will produce quicker and larger profits, than when employed in the slow improvement of agriculture."22

Taylor's agrarianism should not discount his attachment to free markets. A disciple of Adam Smith, according to one historian, Taylor "applauded economic ambition, consumptive goals, and profits as high as one can earn by honest labor and fair exchange." 23 His dedication to laissez-faire did not interrupt his opposition to what was becoming a fixture of free-market economies-financial capitalism. To suggest, as Hammond has, that Taylor's opposition was based on an agrarian "ignorance of banking" is inaccurate. Neither is it correct to imply that Taylor's opposition lent itself to an unbridled entrepreneurialism. ${ }^{24}$ These characterizations

\footnotetext{
${ }^{20}$ John Taylor, Construction Construed and Constitutions Vindicated (Richmond, 1820), p. 89.

${ }^{21}$ John Taylor, Arator: Being a Series of Agricultural Essays, Practical and Political (Baltimore, 1817), p. 24.

${ }^{22}$ Ibid., p. 29.

${ }^{23}$ Paul Conkin, Prophets of Prosperity: America's First Political Economists (Bloomington, IN, 1980), p. 61.

${ }^{24}$ Hammond, Banks and Politics in America, pp. 35, 741.
} 
minimize the complexities of Taylor's republican distrust of finance. It was entirely possible to champion free markets while simultaneously attack finance. Taylor's republican economic thought was a prominent strain in the antebellum literature, one that embraced a nuanced version of laissez-faire-republicanism and expressed concerns of Americans genuinely bothered by financial institutions. His economic thought was at the crossroads of republicanism and liberalism. He did not attack free markets; he made war on financial corporations.

The laissez-faire, anti-finance position of Taylor reflected structural changes taking place in the antebellum economy. Opponents like Taylor struggled to reconcile their attachment to free markets with financial institutions. The modern financial economy, with its regional, national, and sometimes global credit networks tied even the most disconnected market participants to the complexities of finance. Credit as form of social mutuality, or trust, facilitated network-building in the commercial community, and credit offered numerous economic opportunities. But credit also made individuals vulnerable to an interdependent and sometimes arbitrary economic order where mutuality felt like dependency. Only recently have historians started to explore the effects of financial institutions on the social and cultural character of antebellum America. Public attitudes toward finance, particularly debt and insolvency began to change during the early 1800's. The traditional understanding of economic failures as consequence of personal indiscretions and moral culpability was replaced by an awareness that insolvency could result from market pressures outside an individual's reach and that failure was to some degree inherent to antebellum commercial enterprises. ${ }^{25}$

Republican anti-finance showcased the trouble many Americans had in accepting the social externalities of the financial revolution. Their commitment to an idealized past characterized by hierarchical relations was shaken at its very foundations by the expansion of

${ }^{25}$ Edward Balleisen, Navigating Failure: Bankruptcy and Commercial Society in Antebellum America (Chapel, Hill, NC, 2001); Bruce Mann, Republic of Debtors: Bankruptcy in the Age of American Independence (Cambridge, MA, 2002); Scott Sandage, Born Losers: A History of Failure in America (Cambridge, MA, 2005). 
financial capitalism. To some historians, this has been taken to mean that republican economic thinkers were backward looking in all aspects of their thought. Gordon Wood argues that the republican synthesis of the antebellum period was "essentially anti-capitalistic." According to Wood, republicanism represented "a final attempt to come to terms with the emergent individualistic society that threatened to destroy once and for all the communion and benevolence that civilized men had always considered to the be the ideal of human behavior." ${ }^{26}$ In fact, however, Wood's interpretation of republican ideology in early America simplifies the ideological retinues of Taylor and other republicans. Wood and other historians fail to understand the republicanism of America that both accepted free markets yet held finance capitalism in contempt.

The South Carolina economist Thomas Cooper exemplifies this point. Cooper in many ways stands as the essential representation of how free marketers treated finance. As we saw in chapter 3, Cooper vigorously advanced laissez-faire principles. He attacked financial institutions for the same reason he criticized tariffs. Finance and tariffs derived from corrupt legislatures pandering to the interests of capitalists. Cooper, however, broke from the earlier generations of republicans like Taylor in distinct ways. He integrated into his opposition to finance a more explicit defense of free-market institutions. Cooper also neglected to engage in the type of romantic eulogies of an agrarian, pre-capitalist, primitive economy that were characteristic of Taylor's thought. ${ }^{27}$

Cooper's republican opposition to finance was also based on political and social theory. He opposed the incorporation of banks on constitutional grounds. "I am unshaken in my

\footnotetext{
${ }^{26}$ Wood, The Creation of the American Republic, p. 418.

${ }^{27}$ Cooper, Lectures on the Elements of Political Economy (1831; reprint, New York, 1971), pp. 194-195, 78. By the 1820s Cooper had largely abandoned the agrarianism of his earlier publications, ie: Thomas Cooper, "Foreign Commerce" (1813), ed., UdoTheil, Philosophical Writings of Thomas Cooper (Bristol, U.K., 2001), vol. I, pp. 161-165.
} 
opinion," Cooper argued, "that every bank charter is unconstitutional: depriving the great majority of citizens, of rights...and conferring exclusive privileges on another class, upon motives and pretense often fraudulent, seldom excusable, never justifiable.” Bank speculators and legislators, Cooper found, "have too much of a fellow feeling." ${ }^{28}$ Corporate limited liability especially, he charged, sanctioned "a mode of swindling" that sacrificed the earnings of decent laborers to the risks and misjudgments of others. ${ }^{29}$ "I REST ON REPUBLICAN PRINCIPLES," Cooper declared, "a monopoly of privilege, with power of acquiring profit without limitation, conferred on persons whose liability to pay their debts does not extend beyond the share of which they posses in a joint stock of a privileged company, is a fraud on the honest and confiding part of the public." ${ }^{30}$ Corporate proprietors accumulated debts without incurring any responsibility beyond their invested stake. For Cooper, this standard corporate practice discouraged community trust. Absolving a man from repaying debt flew in the face of traditional standards of social and moral justice. "How then are they to know to what extent to trust this company, who may (as often has been done) divide their principal, as a dividend of annual profits, and then sell out to unsuspecting purchasers not in the secret?"31

Cooper represents a shift in the intellectual development of American republican criticisms of finance. ${ }^{32}$ Cooper's critique of finance relied less on the agrarian values that characterize Taylor's work. His Lectures on the Elements of Political Economy was published the same year as Jefferson's death (1826), and the work signifies a kind of changing of the guard. As the nation matured Southern economic thought grew attached to an anti-statist disposition.

\footnotetext{
${ }^{28}$ Cooper, Lectures on the Elements of Political Economy, p. 178.

${ }^{29}$ Ibid., p. 247.

${ }^{30}$ Ibid., p. 251.

${ }^{31}$ Ibid., p. 251.

${ }^{32}$ Cooper actually supported Biddle in his quarrel with Jackson. For Cooper, executive authority was the greater threat.
} 
Although Taylor railed against state intervention in financial markets, his opposition to finance was not tied to a defense of slavery. For Cooper, opposition to finance was couched in a statesrights, pro-slavery ideology. Southern political economists employed republicanism more as a supplement to laissez-faire. Cooper developed this line of thought by synthesizing anticorporatist republicanism and laissez-faire arguments for a circumscribed federal government. ${ }^{33}$ Cooper's opposition to finance was also focused more on the corporatist model of bank charters. He favored free-banking, or, the end of chartered corporations with debt liabilities limited to their subscriptions. Like many republicans of the Jacksonian era, Cooper recognized finance as an integral piece of the nineteenth-century economy. Thus, his reforms aimed at limiting the influence financial institutions had on legislatures. Free-banking, Cooper argued, would encourage conservative lending practices and institute in banking a renewed ethic and responsibility. "I have no objection in great and expensive undertakings to joint stock companies," Cooper wrote, "but the common law of partnership is equity, viz: those who claim a dividend of unlimited profits, are liable to the loss." "All this can be managed well enough without the interference of government or the legislature," Cooper continued, "who are seldom known to meddle but to do mischief...we may surely venture in this new country to say, when our rulers attempt to regulate the private investment of capital, 'let us alone."'34

Cooper's free-banking approach reflected a society growing more accepting of the economic benefits afforded by financial institutions. By 1820 there were over 350 banks in the United States. In the five years that followed Jackson's so-called war on banks, an additional 200 banks were established. ${ }^{35}$ During this period, in the South there was a $130 \%$ increase of notes in

\footnotetext{
${ }^{33}$ Abram Flora, "Economic Thought in South Carolina, 1820-60," (Ph.D. diss., University of North Carolina, 1957), pp. 68-120.

${ }^{34}$ Cooper, Lectures on the Elements of Political Economy, p. 253.
} 
circulation; in the wild-cat West a 100\% increase; and in the more conservative East a $50 \%$ increase. ${ }^{36}$ All the while specie reserves in most cases hovered around 4\%. The proliferation of banks corresponded with the expansion of other financial and monetary institutions. By 1830 there were approximately 10,000 business corporations in the United States. Stock exchanges in New York and Philadelphia traded securities, debt, and commercial notes on margin and were informed by credit reporting agencies. A seemingly perpetual call for more credit could be heard for much of the antebellum period. The financial sector responded accordingly by facilitating information symmetry and licensing some 1500 banks by 1857, all of which helped monetize and integrate a financial system that by 1860 had over $\$ 6$ billion invested in the American economy. ${ }^{37}$

The financialization of the antebellum economy is not, however, evidence that American hostility toward finance was insignificant. Financial institutions developed in spite of the antifinance consensus that marked the period's economic literature. Indeed, even the advocates of finance agreed that certain tendencies of financial institutions were damaging to the social and economic fabric of America and thus required state oversight.

During the second-half of the antebellum period Whigs were consistently the group that advocated the development of American finance. ${ }^{38}$ And like the laissez-faire republicans, Whigs

\footnotetext{
${ }^{35}$ Hammond, Banks and Politics, p. 563. By comparison, in England there were approximately 440 banks in 1845. At the same time, in Scotland there were 24. ed. Robert Harry Inglis Palgrave, Dictionary of Political Economy (London, 1894), vol. I, pp. 91-95.

${ }^{36}$ Between 1830-1837, 347 banks were chartered, Reginald Charles McGrane, The Panic of 1837: Some Financial Problems of the Jacksonian Era (Chicago, 1965), p. 13; Robert Wright, The Wealth of Nations Rediscovered: Integration and Expansion in American Financial Markets, 1780-1850 (New York, 2002), p. 159; Hammond, Banks and Politics, p. 453.

${ }^{37}$ Wright, The Wealth of Nations Rediscovered, pp. 7, 15, 82, 90, 128, 130-132; John Steele Gordon, An Empire of Wealth: The Epic History of American Economic Power (New York, 2004), p. 200; Hammond, Banks and Politics, pp. 596, 628; Richard Sylla, "Monetary Innovation in America," The Journal of Economic History (March, 1982), p. 26; Banner, Anglo-American Securities Regulation, pp. 163, 192, 196; Howard Bodenhorn, A History of Banking in Antebellum America: Financial Markets and Economic Development in the Era of Nation Building (Cambridge, 2000), pp. 85, 162, 167; William Shade, Banks or No Banks: The Money Issue in Western Politics, 1832-1865 (Detroit, 1972), p. 37.
} 
blurred the lines of economics and ideology. The Whigs backed the modernization of American financial institutions, but they did so from a decidedly anti-market position. The Whig model for developing antebellum finance was driven by state initiatives. In the antebellum economic discourse, arguments in favor of expanding finance were typically set in a broader economic agenda that was hostile to market imperatives. Put differently, the champions of American finance were often the enemies of free markets.

This is not to say all Whigs conformed to a statist program. Whigs exhibited flexibility in their policy and ideological positions toward finance. And while Whigs were in the avantgarde of the movement to modernize the domestic economy, many within the Party expressed serious reservations over the social externalities associated with the expansion of finance. ${ }^{39}$ Whigs had the appetite for the financial capitalism, but only so long as finance was carefully managed by legislatures.

The New Englander Nathan Appleton exemplified Whig ambiguities toward finance. A 'cotton Whig,' financier, merchant, and principal of the 'Boston Associates,' Appleton articulated the Whig case for restricting the expansion of banking. Born in New Hampshire in 1779,

\footnotetext{
${ }^{38}$ During the Van Buren, Harrison and Tyler administrations 90\% of Whigs in Congress supported national bank bills. Ashworth, Slavery, Capitalism, and Politics in the Antebellum Republic, p. 401. Conservative Democrats stopped Van Buren's Independent Treasury legislation and Locofoco men did not endorse a candidate in the election of 1836, Walter Hugins, Jacksonian Democracy and the Working Class: A Study of the New York Workingmen's Movement, 1829-1837 (Stanford, 1960), p. 43. Michael Holt, The Rise and Fall of the American Whig Party: Jacksonian Politics and the Onset of the Civil War (Oxford, 1999), p. 68. It seems, however, that Whigs and Democrats equally lacked political principles when it came to their position on finance. There were exceptions to Whig support for banks. James Roger Sharp, The Jacksonians versus the Banks: Politics in the States After the Panic of 1837 (New York, 1970), provides state-by-state analysis of how Whigs viewed banks and shows how banks often times did not provide for a party litmus test. In Louisiana, for instance, Whigs were moderate in their support for banks and could be found expressing reservations. Arthur Cole, The Whig Party in the South (Washington, 1913), shows that many Southern Whigs before the suspension of payments in 1837 were anti-bank. Edward Pessen, Jacksonian America: Society, Personality, and Politics (Homewood, IL, 1978), pp. 214-217, shows that both Whigs and Democrats lacked ideological consistency. Lee Benson, The Concept of Jacksonian Democracy: New York as a Test Cast (New York, 1967), notes that Van Buren's Albany Regency originally attacked the anti-monopoly position, pp. 93-94.

${ }^{39}$ Louis Hartz, The Liberal Tradition in America: An Interpretation of American Political Thought Since the Revolution (New York, 1955),pp. 89-111, Clinton Rossiter, Conservatism in America (Cambridge, MA, 1982), p. 41.
} 
Appleton became a leader in American industry. He was one of the founders of the manufacturing complexes at Waltham and Lowell. Appleton also served in the Massachusetts House of Representatives, was elected to Congress in the early 1830s as an anti-Jacksonian, and later in the 1840 s as a Whig. He died in $1861 .^{40}$

Appleton's critique of antebellum banking echoed the concerns of America's commercial and industrial elite. He was suspicious of the entrepreneurial nouveau riches that the domestic banking system encouraged. Appleton's criticisms were different from republican opponents. Agrarian hostility toward banks, he wrote, derived "from a superficial view of the subject." Still, Appleton criticized the role of reckless bank directors for abandoning moral responsibility in their business practices. Suspension of payments in particular, once a rarity that he considered "an opiate, which if justifiable at all, can only be justifiable where the paroxysms are so violent as to endanger life," Appleton chided for having become a regular fixture of the domestic economy. ${ }^{42}$ In this way Appleton confirmed the social concerns of Taylor. Bank suspensions amounted to an act of ethical impropriety. "It is difficult to perceive how honorable men," Appleton wrote, "holding the office of bank directors, can reconcile a continued suspension to a proper sense of moral obligation." 43

Appleton broke with republican critics, however, by attaching to his paternalistic review of banking upstarts a discussion of the wider social and economic benefits provided by sound financial institutions. Credit was fundamental to the national economy, as was paper currency, he

\footnotetext{
${ }^{40}$ For a discussion of Appleton's investments and political involvement in antebellum banking see Robert Dalzell, Enterprising Elite: the Boston Associates and the World they Made (New York, 1987), pp. 93-97; Francis Gregory, W. Nathan Appleton, Merchant and Entrepreneur, 1779-1861 (Charlottesville, VA, 1975).

${ }^{41}$ Nathan Appleton, An Examination of the Banking System of Massachusetts, in Reference to the Renewal of the Bank Charters (Boston, 1831), p. 43.

${ }^{42}$ Nathan Appleton, Remarks on Currency and Banking; Having Reference to the Present Derangement of the Circulating Medium in the United States (Boston, 1857), p. 16

${ }^{43}$ Ibid., p. 17.
} 
argued. Contrary to hard-money activists, paper currency was more practical than a metallic medium. Neither were currency brokers parasites preying on an unsuspecting public. They afforded a legitimate public service in exchanging notes disfavored by the community. To counter the negligent bank directors of the so-called 'wildcats,' Appleton recommended, in the words of one historian, "mechanisms for enforcing responsibility." ${ }^{44}$ He suggested restrictions on the ability of banks to issue currency with a stringent specie-to-note ratio of $20 \%$ and a $3 \%$ tax on circulating notes. ${ }^{45}$ Appleton figured the latter would reduce the profitability of banks whose only function was issuing notes for circulation. His aim was to abolish banks established for speculative purposes. The merits of market competition, according to Appleton, should not preclude the establishment of highly capitalize national and regional banks from policing the smaller country banks.

Appleton's position reflected the entrenched financial and industrial interests that populated the elite ranks of the New England Whig party. Their opposition did not originate from republican concerns. And, unlike Cooper, they exhibited little confidence in market mechanism to facilitate financial expansion. Appleton did however, share with republican and laissez-faire opponents anxiety over certain social effects of finance. Indeed, their call for state management over financial markets indicates that even within the New England Whig business mainstream, there circulated serious reservations over the nature of financial institutions. ${ }^{46}$

Not all Whigs shared a statist perspective on financial matters. Richard Hildreth, for instance, offered what stands as the most acute Whig endorsement of free-banking. For Hildreth, support of financial institutions did not necessitate abandonment of laissez-faire principles. His dedication to free markets, yet his opposition to financial corporatism conflicted with

\footnotetext{
${ }^{44}$ Dalzell, Enterprising Elite, p. 97.

45 Appleton, An Examination of the Banking System of Massachusetts, p. 39.

${ }^{46}$ Dalzell, Enterprising Elite, p. 97.
} 
conventional Whig thought. Hildreth's free-market critique of finance indicates that some Whigs corresponded to the republican anti-finance movement. Born in 1807, Hildreth's seminal work was a six-volume History of the United States published between 1849 and 1852. Harvard educated, abolitionist, poet, essayist, moral philosopher, and founder and editor of the Bostonbased Whig paper the Atlas, Hildreth presented his views of American finance in his 1840 Banks, Banking, and Paper Currencies. ${ }^{47}$

Although Whigs normally supported state intervention in the economy, for Hildreth, however, the financial sector had been ruined by state meddling. He criticized state and national legislatures for disrupting the otherwise natural and sound operations of financial institutions. State intervention in the financial sector was originated from strictly political motivations, Hildreth concluded. Jacksonian opposition to finance was, Hildreth argued, "for the purpose of creating a new bank, the stock of which might be shared among their friends and partisans." The state banks that fought against Biddle were rewarded the following year with the redistribution of federal deposits, the "spoils of victory" according to Hildreth. ${ }^{48}$ This was not unusual, for no matter their political disposition "it was most amply justified by the practice of all our legislative bodies, which have ever been in the constant habit of confining the grant of bank charters to influential persons of the prevailing political party." $" 49$

Hildreth's rebuke of political finance was rare for antebellum Whigs. His anticorporatist, laissez-faire criticisms of the BUS showcased the complexities in the Whig financial discourse. It also indicates a lack of consensus within the pro-finance movement. Hildreth advocated banking be controlled not "at the mercy of ignorant and reckless politicians, or at the mercy, no less to be deprecated, of a few purse-proud, domineering, dictatorial bank directors,"

\footnotetext{
47 Arthur Schlesinger, "The Problem of Richard Hildreth,” The New England Quarterly (June, 1940).

${ }^{48}$ Richard Hildreth, Banks, Banking, and Paper Currencies: In Three Parts (1840; reprint, New York, 1968), p. 87.

${ }^{49}$ Ibid., p. 84.
} 
but by the "Laws of Trade-laws which do not act by jerks and starts... but by a constant, steady, gentle, yet inevitable pressure. ${ }^{, 50}$ Hildreth's recommendations amounted to free banking. He disparaged the national bank, referring to the institution as a "sort of absolute monarch." Hildreth argued that by eliminating the monopoly control of the national bank, along with promulgating general laws for bank incorporations, market forces would check profligate circulation of notes through regular calls for redemption. ${ }^{51}$ Hildreth was aware of the speculative and corrupt tendencies of financial institutions. However, his admiration for banks as agents of economic progress combined with his desire to see the financial sector expand freed from the fetters of state makes Hildreth something of an anomaly in the antebellum discourse.

The reforms suggested by Whigs like Appleton and Hildreth were amplified by the opposition movement of the later-antebellum period (1830-1860). The later-antebellum opponents of finance expressed a dedication to laissez-faire principles by advocating the absolute withdraw of state intervention from the financial sector. But by forcing banks to conform to market forces, opponents aimed at limiting the social, political, and economic influence of financial institutions. The central features of this literature drew on the republican style of thought that harkened back to John Taylor. "The great banking bubble of American was the same in principle as the South Sea Bubble," a Jacksonian noted, "but of longer continuance, and involved in it the fortunes of the whole community." ${ }^{52}$ Other later-antebellum opponents widened criticisms of earlier republicans to challenge the foundational principles on which antebellum finance rested.

Republican political economy continued to serve critics as a vehicle to attack finance.

But in this case republicanism was not engaged as a medium to articulate an agrarian hostility

${ }^{50}$ Ibid., p. 153.

${ }^{51}$ Ibid., pp. 172, 146-148.

${ }^{52}$ William Gouge, The Curse of Paper Money and Banking, or, A Short History of Paper Money and Banking in the United States of America (1833; reprint, New York, 1968), p. 87. 
toward capitalism. More than the Augustan English and Southern detractors like Taylor, the later-antebellum critics recognized finance as a permanent staple of a free-market system most cherished. Like Cooper, they fused a more explicit and thorough synthesis between republicanism and laissez-faire.

The later-antebellum critics certainly found the same reasons as earlier republicans to condemn the moral dangers of finance. Financial institutions were responsible for engendering a social psychology marked by a frantic mental state that surrendered all rational thought.

Financiers employed "every art of cajolery and allurement...excited a thirst for speculation...until it increased to a delirious fever, and men, in the epidemic frenzy of the hour, wildly rush upon all sorts of desperate adventures." ${ }^{53}$ Profligate extensions of credit and specious expansions of paper money induced "a reckless fanatical spirit of speculation, unparalled, perhaps, in the history of the world." ${ }^{54}$ Finance also normalized a debased ethic in commercial affairs that undermined social morality and justice. The financial system "is wrong in principle, and must be ruinous in its effects on the integrity, the morals and the ultimate prosperity of a people." ${ }^{55}$

Antebellum critics kept to the traditions of republican political economy by focusing much of their contempt on credit. Credit created a socio-economic order based on fantasy and delusion. "A very uncertain and fluctuating thing," credit contorted reality by distoring personal and social estimations of an individual's wealth. ${ }^{56}$ Mental and emotional psychoses were offshoots of a frenzied credit-filled atmosphere "that madden the brains of whole communities,"

\footnotetext{
${ }^{53}$ William Leggett, "Thoughts on the Causes of the Present Discontents," Lawrence H. White, ed., Democratic Editorials: Essays in Jacksonian Political Economy (Indianapolis, 1984), p. 97.

${ }^{54}$ Theophilus Fisk, Labor The Only True Source of Wealth; or the Rottenness of the Paper Money Banking System Exposed, Its Sandy Foundations Shaken, Its Crumbling Pillars Overthrown (1837; reprint, New York, 1970), p. 8.

${ }^{55}$ Fitzwilliam Byrdsall, History of the Loco-Foco or Equal Rights Party (1842; reprint, New York, 1967), p. 139.

${ }^{56}$ William Gouge, January 19, 1842, The Journal of Banking, July, 1841-July, 1842 (1842; reprint, London, 1996), p. 228.
} 
casualties of a banking system that served as "the insane root that takes the reason prison. ${ }^{57}$ Credit also transformed the social division of labor by promoting speculation and encouraging Americans to avoid traditional forms of labor. The plough stood idle, the merchant square vacated, and the workshop fell silent, "while to those employed in the paper money laboratories, the temptations to fraud and peculation are so strong, and the opportunities so inviting, that many men of ordinary honesty are thereby turned into rogues." ${ }^{15}$ In short, credit slowed the progress of market-driven economic development. Credit was also damned for its association with debt. Indebtedness was akin to slavery; the person and property of debtors subjugated to the whims of creditors. A source of humiliation and shame, debt signified the worst kind of oppression, for a debtor was always "reduced to the condition of his bondsman or serf." "The prolific mother of crime," debt "taints the course of life in all its streams." 59

Later-antebellum opponents used similar rhetorical strategies as earlier republican critics, but they also broke from earlier traditions by intensifying the claim that finance undermined freemarket institutions. As they grew more familiar with the internal operations of banks they began to detect the ways, as they saw it, that banks violated the basic principles of the free market. They harbored special animosity toward the practice of limited liability.

Condy Raguet offered the period's most developed critique of limited liability. Born in Philadelphia in 1784, Raguet was a merchant and journalist by trade, served several terms in the Pennsylvania state senate as a Federalist, and had a brief stint as American consul to Brazil. After diplomatic service, Raguet returned to Philadelphia in 1827 and found himself in the lion's den of protectionism. To counter the protectionist movement, in 1829 Raguet established the

\footnotetext{
${ }^{57}$ William Leggett, "Fancy Cities," Theodore Sedgwick, ed., A Collection of Political Writings of William Leggett (1840; reprint, New York, 1971), vol. II, pp. 86, 103. There was an element of truth in this rhetoric, for during the Jacksonian period asylums listed personal financial trauma as one of the leading causes of insanity. Balleisen, Navigating Failure, p. 79.

${ }^{58}$ George Opdyke, A Treatise on Political Economy (1851; reprint, Clifton, N.J., 1973), p. 293.

${ }^{59}$ Fisk, Labor The Only True Source of Value, p. 15.
} 
Free Trade Advocate. Two years later he organized a Free Trade Convention in Philadelphia attended by the leading laissez-faire spokesmen of the period. ${ }^{60}$

Raguet's criticisms of limited liability were articulated as affirmation of laissez-faire principles. Confidence and responsibility were critical social values in a market economy, both of which were undermined when legislatures failed to hold banks accountable for their debts. Releasing corporate bodies from discharging their debts was an affront to commercial and social integrity. "To destroy all moral sense of justice and rectitude by absolving each individual from personal liability" Raguet wrote, "as if a legislative act could absolve men from the discharge of their moral duties, or which the payment of debts, where there is ability, is one." 61

Raguet's desire for strengthening ethical standards in the financial sector sprung from a laissez-faire disposition. Free markets were effective only in so far as they helped balance private and public interests. Indeed, he held bankers to a higher set of socially responsible values in order to foster healthy and honest competitive financial markets. Acts of incorporation did not pardon men for acts of impropriety. Raguet suggested enforcement of strict convertibility of paper notes. By holding corporate investors and bank directors responsible for their paper obligations, "the over-trading of each particular bank would be checked by the prudent regard to self-interest which would operate upon its managers; and if recklessness should characterize the conduct of one, or a dozen, or a hundred, it or they would simply fail, like individual traders." 62

Raguet contributed to a widening literature in the later-antebellum period that highlighted the social injustices perpetuated by financial institutions. These tendencies, according to Raguet and others prevented the expansion of market economies. Much of this literature focused on the

\footnotetext{
60 "Sketch of the Life and Character of CondyRaguet," The Merchant's Magazine (December, 1842), pp. 543-544; Malcolm Rogers Eiselen, The Rise of Pennsylvania Protectionism (1932; reprint, New York, 1974), pp. 92-98.

${ }^{61}$ CondyRaguet, A Treatise on Currency and Banking (1840; reprint, New York, 1967), p. 167.

${ }^{62}$ Ibid., p. 103.
} 
supposed evils of paper currency. Paper notes represented fictitious values, at times redeemable for fractions of their alleged worth, at other times not redeemable at all, but at all times a "fraudulent system of money making out of rags." A bank note was simply a debt, a "paper trash" containing "no intrinsic value and which a breath of public suspicion may at any time destroy." ${ }^{63}$ Moreover, critics charged that specie convertibility was a farce. It was tacitly understood that paper notes were not backed by bullion. "All men of ordinary sagacity know that the representative character of convertible paper money is, in part at least, an ingenious fiction. ${ }^{64}$ Indeed, as one cynic wrote, "the whole amount of the precious metals scattered throughout the world, would scarcely be sufficient to redeem the paper credits of the United States." 65

Later-antebellum opposition to paper currency should not be confused for an anticapitalist ideology. Indeed, the opposition literature insisted that by revolutionizing financial institutions a more durable free market would emerge, promoting the interests of business and labor and encouraging economic growth. Wild fluctuations in currency values traumatized market participants. "Its tendencies are eminently demoralizing. By its alternate and ever recurring expansions and contractions of the money machine, it keeps the standard of value constantly vibrating. This unsettles business as well as prices; it makes fortunes and mars them; it excites men's gambling propensities...it leads to recklessness, extravagance, and immoral practices." 66

\footnotetext{
${ }^{63}$ Stephen Simpson, The Working Man's Manual: A New Theory of Political Economy on the Principle of Production the Source of Wealth (Philadelphia, 1831), p. 143; Theophilus Fisk, The Banking Bubble Burst; or the Mammoth Corruptions of the Paper Money System Relieved by Bleeding (Charleston, 1837), pp. 23, 24

${ }^{64}$ Gouge, The Curse of Paper Money and Banking, p. 79

${ }^{65}$ Fisk, Labor The Only True Source of Wealth, p. 18.

${ }^{66}$ Opdyke, A Treatise on Political Economy, p. 293.
} 
William Gouge was the period's most distinguished laissez-faire opponent of paper money. Born in 1796, his 1833 The Curse of Paper Money and Banking: or A Short History of Paper Money served as "the bible" of the Jacksonian hard-money movement, was widely read, and earned Gouge an international reputation on banking. ${ }^{67} \mathrm{~A}$ journalist and publisher by trade, Gouge also worked intermittently in the Treasury Department for 30 years. ${ }^{68}$ In 1841 he edited the Jacksonian Journal of Banking. There he repeated the standard Jacksonian maxim, "we are friendly to free banking." But Gouge was referring only to banks of deposits, lending and discount, not to the free issue of notes. "Free competition in paper money banking would be little more than a competition of cunning," fostering a commercial environment that was "essentially evil." ${ }^{69}$

Gouge exhibits the various shades of ideological distinctions that Americans harbored in their opposition to finance. He imagined himself a "disinterested political economist" responsible for helping Americans understand that prevailing economic difficulties were the effects of"a Banking system resting on principles fundamentally erroneous." ${ }^{70}$ Gouge was not anti-capitalist. Rather he defended adamantly the sanctity of private property and the accumulation of wealth. His denunciations of corporate banks and demands for replacing the paper currency with a metallic medium were couched in a Smithian laissez-faire ideology. These associations were not incompatible in the antebellum discourse. Neither was Gouge's hard-money program suggestive

\footnotetext{
${ }^{67}$ Joseph Dorfman, "William H. Gouge and the Formation of Orthodox American Monetary Policy," Gouge, A Short History of Paper Money, p. 5; Joseph Blau, "Biographical Notes," Joseph Blau, ed., Social Theories of JacksonianDemocracry: Representative Writings of the Period, 1825-1850 (New York, 1954), p. 372 .

${ }^{68}$ Conkin, Prophets of Prosperity, pp. 207-208; Benjamin Rader, “William M. Gouge Jacksonian Economic Theorist," Pennsylvania History (October, 1963), pp. 443-453.

${ }^{69}$ Henry Gouge, June 8, 1842, The Journal of Banking, p. 387.

${ }^{70}$ Dorfman, "William H. Gouge and the Formation of Orthodox American Monetary Policy," Gouge, The Curse of Paper Money and Banking, p. 25; Henry Gouge, July 7, 1841, The Journal of Banking, p. 3.
} 
of a labor/agrarian extremism as some historians have implied. "Make gold and silver coins the exclusive money of the country," Gouge declared, "and the evils of the system would be greatly diminished." 72 He genuinely believed paper currency hindered economic growth. Gouge helped bring legitimacy to the hard-money movement by outlining the feasibility of abolishing paper money. What he and other hard-money advocates expressed was a growing desire among Americans of various classes and politics for a practical though revolutionary alternative to the prevailing monetary order. ${ }^{73}$

Gouge's writings demonstrate that the hard-money movement articulated criticisms entirely compatible with laissez-faire values, and thus centered squarely in the antebellum mainstream. Most Jacksonian opponents were not radical outliers. Neither were opponents necessarily interested in reforms intended to democratize and cheapen access to credit markets. The opposition movement was led by individuals who found finance anathema to both social justice and laissez-faire principles, and thus sought reforms aimed at preserving market institutions.

The Massachusetts lawyer Lysander Spooner illustrates this point. Spooner's criticisms were reminiscent of republican conventions; however they were marked by an exaggerated commitment to laissez-faire values. Born in 1808 , as a young man he spent years under the legal tutelage of future Chief Justice Charles Allen. Although he served for a short period as a clerk at Albert Gallatin's National Bank of New York, Spooner's understanding of American finance was reached during the Panic 1837. At the time, Spooner was speculating in Ohio land. The crisis

\footnotetext{
${ }^{71}$ Hammond suggests this by positioning his analysis of Gouge alongside an agrarian opposition that he characterized as disingenuous, Banks and Politics in America, pp. 608-612. Schlesinger makes this inference by situating Gouge in the context of radical labor, The Age of Jackson, pp. 117-121.

${ }^{72}$ Gouge, The Curse of Paper Money and Banking, pp. 113, 218

${ }^{73}$ Gouge's book was in the words of Schlesinger "an instant success," The Age of Jackson, p. 118. It went through a number of additions within his lifetime. Jackson's Treasury Secretary Levi Woodbury initiated a national policy to prohibit the circulation of notes under $\$ 20$.
} 
sent Spooner back to his father's farm in rural Massachusetts to contemplate transformations in finance. Spooner published his ideas in Poverty, Its Illegal Causes and Legal Cure (1846) and later The New System of Paper Currency (1861). ${ }^{74}$

Today Spooner is remembered as one of America's most prolific philosophical anarchists. He was in essence, an anarcho-capitalist determined to maximize individual sovereignty through an extreme form of free-market economics. His commitment to laissez-faire principles was unequivocal. Spooner's devotion to free markets motivated his distrust of finance.

To reform financial markets, Spooner suggested significant alterations to the procedures behind debt collection. These measures were reminiscent of earlier republican demands to reestablish credit networks on a more intimate basis. Spooner's program would have revolutionized the financial order. Still, Spooner's reforms had as their ultimate goal a financial system constructed along strict laissez-faire models. At the maturation of a debt, Spooner argued, the borrower was liable only for what could he could muster up at that moment. Debt, Spooner figured, "has no legal obligation, and generally no moral one, beyond the means of the debtor to pay at the time the debt becomes due." Since none could predict what might become of an enterprise, all contracts and obligations made without provisioning for "all the contingencies and accidents that may occur to defeat his purposes" were "void from the beginning." 75 According to Spooner debt was the equivalent of a value purchased by creditors subject to rise or fall throughout the term of the loan. The value of a debt, like all property, was exposed to market risks and thus carried the potential for variation. A lender assumed as much risk and responsibility for a debt as the borrower. In short, Spooner called for the abolition of laws in the collection of debt. Doing so would tighten credit and incline lenders to investigate the substance

\footnotetext{
${ }^{74}$ Dorfman, The Economic Mind in American Civilization, vol. II, p. 674.

${ }^{75}$ Lysander Spooner, Poverty, Its Illegal Causes and Legal Cure (1846; reprint, New York, 1971), pp. 65, 66.
} 
of a borrower's plans. Spooner articulated absolute confidence in the market to provide creditors with perfect information on individual borrowers. "When a capitalist loans money to a laborer...he does not look, for himself, into the merits of the enterprise as he would if he knew that his ultimate security for his capital depended solely upon the success of the enterprise, instead of depending also upon the subsequent earnings of the laborer." ${ }^{76}$

Spooner is the essential representation of an exaggerated free-banking ideologue. At the core of his analysis is the desire for credit networks that operated on a more personal level. This was in line with both classical republican and free-market values. Opponents of finance typically eulogized the economic tranquility of times past, where credit relations were shared between intimates rather than unfamiliar, corporate institutions. "In the old fashioned way of credit," one critic figured, "few men were enabled to go so much in debt, as that they would not be detected in time to save their creditors." ${ }^{77}$ Spooner's desire to restore personal credit relations was not a manifestation of an anti-market ideology. Indeed, state intervention on behalf of financial institutions in the processes of debt collection undermined the free-market order.

George Opdyke, one-time mayor of New York City and prominent figure in the Free Soil and Republican parties, also worked to tighten the bonds between creditor and borrower as a means to advance laissez-faire principles. Born in 1805 in New Jersey he grew familiar with finance through his business associations in New York City’s Chamber of Commerce. ${ }^{78} \mathrm{He}$ presented his views on finance in his 1851 A Treatise on Political Economy. A dry goods chain storeowner turned self-made millionaire, for a time Opdyke's textile and merchandising businesses were the largest in New York City. He died in 1881.

\footnotetext{
${ }^{76}$ Ibid., p. 31. See also Lysander Spooner, The New System of Paper Currency (Boston, 1861), p. 43.

${ }^{77}$ George Clinton, Essays on Banking (Richmond, 1829), p. 11.

${ }^{78}$ Dorfman, The Economic Mind of American Civilization, vol. II, pp. 755-757; “George Opdyke Dead: Death of a Prominent Citizen and Former Mayor of New York," The New York Times, June 13, 1880.
} 
Opdyke was no extremist, but his suggested reforms were nothing short of radical. He epitomized the slippery ideological disposition of republican critics of finance. The anti-tariff, anti-slavery, big-city businessman who as a Republican would later call for an irredeemable national currency was not anti-capitalistic; nor does he come across as an entrepreneur thirsting for cheap credit. Rather Opdyke is genuinely interested in removing the socially damaging features of antebellum finance. He employed traditional republican rhetorical strategies in his description of financial institutions. Opdyke likened credit markets to a game of hide and seek. "As the matter now stands...it is accounted meritorious to evade the payment of an honest debt." "Creditors look more to the law than to honesty or honor of their debtors for the enforcement of payments," Opdyke continued, "and while such is the case we must expect that evasions of payment will be regarded as skillful achievements over the law and the sagacity of creditors, rather than as acts of dishonor." Under existing circumstances the abolition of laws for the collection of debt seemed the only viable option. This would ensure that creditors had adequate knowledge of a borrower's capacity for repayment. Extensions of credit would rest on the decency and moral constitution of men rather than legal recourse. "Increase the demand for integrity of character, frugality, and diligence, by basing credit exclusively upon them, and you will soon stimulate and develop these desirable qualities of character to such a degree that any one who should prove so far deficient therein as to refuse payment of a debt... would be utterly discountenanced in all respectable society." ${ }^{79}$ Curtailing state involvement in creditor-debtor disputes and forcing lenders to employ discretion in their credit extensions promised a moderate, more prudent set of lending standards. "Increase the demand for virtue and you will increase the supply; enlarge its reward and you will not fail to improve its quality, and thereby elevate the national standard of morality." 80

\footnotetext{
${ }^{79}$ Opdyke, Treatise on Political Economy, p. 318.
} 
The desire to reinstate traditional methods of credit networks based on intimate relations harkened back to earlier republican criticisms. But in removing legal institutions from the process of debt collection, later-antebellum opponents placed greater emphasis on market imperatives than earlier republican like Taylor. Spooner and Opdyke employed republican values as a medium to advance laissez-faire principles. Their ultimate goal, unlike earlier republican critics of finance, was not necessarily the construction of an agrarian ideal. Rather republicanism was a means to a distinctly modern free-market economy. The emphasis given to laissez-faire by later-antebellum critics was also supplemented by traditional republican-based anxieties over state interference in the economy. The fear of financial institutions corrupting legislatures was the most enduring theme of the opposition literature. In this way, laissez-faire and classical republicanism formed its strongest intellectual bond.

The synthesis between liberal-republicanism was given further impetus by William Leggett. Leggett lived an eventful yet shortened life. Born in 1801 in Savannah, Georgia, as a young man he attended Georgetown College. The failure of his father's business curtailed his enrollment, and shortly after Leggett joined the Navy. In 1828 he moved to New York City where he found work as a theatrical and literary critic for local papers. William Cullen Bryant recognized talent in the young man, hiring Leggett as a writer for the Evening Post. Leggett was, however, hindered by Yellow Fever contracted while he was in the Navy. He later became a leader in New York's Locofoco movement, but the disease ended his life just before his fortieth birthday. ${ }^{81}$ Leggett's critique of finance was expressed in two widely-read periodicals that he established in the late-1830s, the Plaindealer and the Examiner.

\footnotetext{
${ }^{80}$ Ibid.,p. 318.

${ }^{81}$ For a discussion of Leggett see Marvin Meyers, The Jacksonian Persuasion: Politics and Belief (Stanford, 1957), chapter 9; Walter Hugins, Jacksonian Democracy and the Working Class: A Study of the New York Workingmen's Movement, 1829-1837 (Stanford, 1960), p. 88; Dorfman, The Economic Mind in American Civilization, vol. II, pp. 653-654.
} 
Leggett solidified the union between laissez-faire and republican principles in the opposition discourse. His writings are further indication that antebellum opposition to finance did not advance an anti-market agenda; rather it served as reaffirmation of the market regime. By resisting the spread of financial institutions Leggett aimed at encouraging competitive markets. These values were hardly outside of the antebellum intellectual mainstream. Indeed, they were fundamental to American economic heritage. For Leggett, the "sister doctrines" of republicanism and laissez-faire were reciprocating ideologies. A stubborn, unbending commitment to Smithian free trade was the driving force behind Leggett's pleas for republican equal rights. ${ }^{82}$ Laissez-faire and republicanism, he declared, advance "the largest liberty...both are equally opposed to all special privileges and immunities; and both would leave men to manage their own affairs, in their own way, so that they did not invade each others natural rights." ${ }^{83}$ Mixing government and business inevitably led to special legislation that corrupted markets and ruined republican polities. Purge society of the "unholy alliance between politics and banking," Leggett demanded, and "let commerce, and let the currency...regulate themselves." ${ }^{14}$

Historians have minimized the intellectual affinities between liberal-republicanism and anti-finance. They have failed to note the compatibility between antebellum laissez-faire and anti-finance. In doing so, they have also largely ignored important theoretical developments in the antebellum discourse. Criticisms of finance provided a medium for opponents to articulate broader economic philosophies. Liberal-republicans drew most heavily on contemporary laissezfaire ideology to attack financial institutions. State intervention in the banking system through corporate legislation was thought by most liberal-republicans obstructions of a natural financial order. The state tarnished an otherwise flawless natural system governed by immutable laws and

\footnotetext{
${ }^{82}$ Meyers, The Jacksonian Persuasion, pp. 202-203.

${ }^{83}$ William Leggett, "The Sister Doctrines," Democratic Editorials, pp. 36-37.

${ }^{84}$ William Leggett, "Connection of State with Banking," A Collection of Political Writings of William Leggett, vol. II, p. 306.
} 
universal principles. "If we do die," Gouge wrote, "it will be of the doctor not of the disease." ${ }^{85}$ To be sure, critics were convinced that there existed an intrinsic evil in finance. But legislative interference exacerbated financial vices by disrupting organic processes with artificially contrived institutions. "If there is something essentially bad in fictitious money, there seems to be something in human nature which prevents it being properly managed." 86

Leggett gave this strain of thought its most lucid expression. His criticisms of finance were comparable to Smith's censures of mercantilism. In an 1837 Plaindealer article Leggett explained the omnipotent character of the natural economic order and the shortcomings of human institutions in their attempts to manage economic phenomena. "While trade is in prosperous operation, it seems governed by laws as fixed and harmonious and to most minds as inscrutable, as those of the universe. Each link in the mighty chain, each part of the prodigious whole, performs its allotted office, and contributes to the grand result-the improvement of the physical and intellectual condition of mankind." Employing language analogous to Smith, Leggett continued, "But when derangement takes place, when any thing occurs to interrupt the harmonious movement, such are the mutual relations and dependence of the various parts, that the inquirer is bewildered in his attempts to investigate the cause of the confusion..." ${ }^{87}$ "Ignorant legislators" promulgated directives in an "attempt to control what is in its nature uncontrollable, and should be as free as air." ${ }^{88}$ In short, markets worked best when left alone. "Leave trade to its laws, as we leave water to the laws of nature, and both will eventually be equally certain to find their proper level." ${ }^{89}$ Rather than liberating finance the state "forces credit out of its natural

\footnotetext{
${ }^{85}$ Henry Gouge, July 29, 1841, The Journal of Banking, p. 20.

${ }^{86}$ Gouge, The Curse of Paper Money and Banking, p. 229.

${ }^{87}$ William Leggett, "The Pressure-The Cause of It-And the Remedy," Democratic Editorials, p. 116.

${ }^{88}$ Leggett, "Fancy Cities," A Collection of Political Writings of William Leggett, vol. II, p. 105.

${ }^{89}$ William Leggett, "Why is Flour so Dear?," Democratic Editorials, p. 94.
} 
channel." ${ }^{90}$ Leggett argued that by freeing financial markets from state management "the simple order of nature" would find encouragement. The financial system would be left to bend naturally to universal directives. "That is most excellent," Leggett declared, "which comes nearest to the simplicity of nature." 91

Leggett's admiration for laissez-faire values demonstrates that the supposed bond between free markets and finance in the popular historical imagination did not exist in the antebellum discourse. The dichotomy maintained in the historiography between republicanism and capitalism masks the complexities of the anti-finance movement. The antebellum economic mind was not shaped by distinct ideological lines. Indeed, support for the expansion of financial institutions was normally espoused by individuals partial to state intervention in the economy. The historiography has also misrepresented opposition as a pretense for unbridled financial entrepreneurialism. Opponents were genuinely disturbed by the moral, social, and political externalities attendant to the spread of financial institutions. Neither were the opponents of finance always militant laborites or radical outliers. The anti-finance movement was inclusive of a wide-range of positions and personalities, few of which operated on the fringes of antebellum intellectual culture. Even high-brow free-trade academics articulated misgivings toward finance. Henry Vethake, for instance, complained of banking speculation as having excited "a corrupt spirit of gambling." 92 And Jacob Cardozo disparaged paper money for having afflicted the world "with a moral evil" more "pestilent and dreadful" than anything that had passed before it. ${ }^{93}$ On the opposite end of the ideological spectrum, George Frederick Holmes denounced "the financial dragons" as "absolutely fatal to public morals...utterly antagonistic to political order or the

\footnotetext{
${ }^{90}$ William Leggett, "Morals of Legislation," Democratic Editorials, p. 53.

${ }^{91}$ William Leggett, "The Natural System," A Collection of Political Writings of William Leggett, vol. II, p. 334.

92 Henry Vethake, The Principles of Political Economy (1844; reprint, New York, 1971), p. 184.

93 Jacob Cardozo, Notes on Political Economy (1826; reprint, New York, 1972), p. 91.
} 
permanent prosperity of States, and must prove the ruin of all governments...They are consuming the vitals of society, and rendering the continuance of social order an impossibility." 94

Then, as in more recent times, serious hostility was directed at financial institutions. Opposition toward finance was so widespread in the antebellum discourse that if anything, the opposition literature constituted American convention. This is not to say the movement to modernize American financial institutions was without support. America's emergence in the twentieth century as a leader in global financial markets shows that pro-bank interests were well represented. What the antebellum discourse on finance illustrates is a deep division in the American economic mind between ideology and practice. Like the debate over industry and trade, the financial literature was marked by a diversity of thought reflective of the broader lack of consensus that permeated the economic discourse.

${ }^{94}$ George Frederick Holmes, "Speculation and Trade," The Southern Quarterly Review (November, 1856), p. $12,27-28$. 


\section{Chapter IX}

Conclusion: The Old and the New in American Economics

The appointment of Charles Dunbar to the chair of political economy at Harvard in 1871 initiated a new era of economic study in the United States. Other institutions followed suit, establishing and later expanding their political economy departments. While the professionalization of economic analysis may have then begun in earnest, this dissertation shows that during the antebellum period the discipline was pursued with comparable levels of intensity. Antebellum political economists demonstrated originality, inquisitiveness, and were relevant participants in the public sphere. Antebellum economic thinkers worked toward the formulation of an economic science suited to the domestic experience, but in no way was American thought insulated from Old World influence. The American writers reviewed in this dissertation were in constant dialogue with European, particularly British thinkers. Although British laissez-faire influenced the antebellum economic thought, classical orthodoxy never dominated the American discourse.

In the post-Civil War period this trend continued. Following the conflict, the influence of laissez-faire classicism over the American economic mind proved just as tenuous as it had been during the antebellum era. Although instruction in political economy after the war was delivered mostly by professors of the laissez-faire persuasion, within the free-trade movement there was sharp disagreement over important principles. ${ }^{1}$ By the early 1870 's classical economics began to rapidly lose its credibility. The same year Dunbar assumed his post at Harvard, the Englishman Stanley Jevon's theory of marginal utility dealt a decisive blow to classical convention by

\footnotetext{
${ }^{1}$ Michael O'Connor, Origins of Academic Economics in the United States (New York, 1974). In 1876 a list of the ten 'most saleable works on political economy' registered John Stuart Mill's Principles of Political Economy and Adam Smith's Wealth of Nations at the top of the chart. Joseph Dorfman, The Economic Mind in American Civilization, 1865-1918 (New York, 1969), p. 81.
} 
discounting Ricardian models of distribution and value. ${ }^{2}$ The collapse of Ricardian orthodoxy, on both sides of the Atlantic, was nothing less than an intellectual revolution.

In America the marginalist movement was largely a home-grown phenomenon. A similar theory was elaborated in John Bates Clark's 1885 The Philosophy of Wealth. The Columbia University professor found value a measurement of utility determined by a series of subjective calculations, both individual and social. ${ }^{3}$ Clark's criticizing of classical orthodoxy was not limited to the theory of value, however. He saw in the industrial and financial behemoths of the Gilded Age reason to question the classical assumption of perfect competition and he also thought humanity driven by motives other than pure economics. ${ }^{4}$ When Clark did finally depose Ricardo's principal tenets of their authority, the American was adapting to an established domestic tradition of subjecting classicism to critical revision. Malthus experienced a similar fall from theoretical grace in the late nineteenth century. Rising standards of living and improved agricultural productivity had proven Malthus' conclusions about population outrunning the food supply wrong. European political economists began to realize what American thinkers had long argued with respect to population.

The post-Civil War breach initiated by Clark was complimented by a methodological rift. Clark, like thousands of other American students during the post-Civil War period studied in Germany and brought back to the United States an appreciation of historical economics. German universities were then captivated by the historicism of Leopold von Ranke, and students of Gustav von Schmoller and Wilhelm Roscher in particular were instructed to challenge the

\footnotetext{
${ }^{2}$ T.W. Hutchison, On Revolutions and Progress in Economic Knowledge (Cambridge, 1978), chapters 3 and 4; Eric Roll, A History of Economic Thought (New York, 1942), pp. 417, 79.

${ }^{3}$ George Tucker had made similar arguments with his psychological theory of value.

${ }^{4}$ Richard Ely, “A Decade of Economic Theory," Annals of the American Academy of Political and Social Science (March, 1900), pp. 96-101
} 
precepts of ahistorical classicism. ${ }^{5}$ American students of the historical school imported the German Methodenstreit to the domestic discourse. The controversy over method came to a head in 1885 when the 'New School'-young economists influenced by German historicism-established the American Economic Association. The organization's founding constitution declared, among other things, "the state as an agency whose positive assistance is one of the indispensable conditions of human progress." And on the progression of the economics discipline, the "New School' conceded that they "appreciate the work of former economists," however "we look not as much to speculation as to the historical and statistical study of actual conditions of economic life..."

There are obvious but largely neglected ties between the principles of the 'New School' and antebellum protectionism. Friedrich List is the obvious conduit, but Henry Carey was also celebrated in Germany for initiating a revolution in economic theory. ${ }^{7}$ Like the antebellum protectionists, the New School economists clamored for a revised and socially engaged political economy. Both envisioned the state as facilitator of economic development and both believed democratic institutions should be employed to promote the people's economic interests. Each gave special emphasis to the inductive method, found economic theory dependent upon prevailing social, political and economic conditions, and both favored practical solutions over academic abstractions. ${ }^{8}$

\footnotetext{
${ }^{5}$ Henry William Spiegel, The Growth of Economic Thought (Englewood Cliffs, 1971), pp. 421-424; Joseph Schumpeter, History of Economic Analysis (Oxford, 1954), pp. 807-812; Erik Grimmer-Solem, The Rise of Historical Economics and Social Reform in Germany, 1864-1894 (Oxford, 2002), pp. 122-126.

${ }^{6}$ Found in Joseph Dorfman, "The Role of the German Historical School in American Economic Thought," The American Economic Review (May, 1955), p. 27.

${ }^{7}$ A.D.H. Kaplan, Henry Carey: A Study in American Economic Thought (Baltimore, 1931), p. 1.

${ }^{8}$ Sidney Fine, Laissez-faire and the General Welfare State: A Study of Conflict in American Thought, 1865-1901 (Ann Arbor, MI, 1969), pp. 198-221.
} 
The New School economists of the late nineteenth century have received more attention in the historiography than their protectionist predecessors. Historians continue to slight the contributions made by antebellum protectionists. But in the antebellum battle of economic ideas it is clear the protectionists triumphed. The promulgation of Treasury Secretary Robert Walker's liberal tariff schedules in 1846 was an American laissez-faire moment in a century otherwise dominated by protectionism. The post-Civil War debate over trade policy further institutionalized the protectionist agenda as the United States did not effectively participate in the global trading community until the early twentieth century. ${ }^{9}$

The primacy of protectionist policy certainly contributed to American industrialization, as well as the expansion of state authority in the economy. The failure of antebellum protectionists to recognize the potential threats to individual liberty by state interventions and to labor by industrial conglomerations speaks more to their lack of perfect foresight and their acceptance of American exceptionalism than a concerted effort to advance the agendas of Republicans and Robber Barons. ${ }^{10}$ Only in the decades that followed the Civil War did most American thinkers begin to believe that the course of American industrialization would follow the British model. The United States, it seemed, was not exceptional. The social difficulties associated with industrialization were criticized most poignantly in the post-Civil War era not by the disciples of Carey but by an expanding body of labor/socialist literature, much of which was anticipated by George Fitzhugh, George Frederick Holmes, Langton Byllesby and Thomas

\footnotetext{
9 Judith Goldstein, Ideas, Interests, and American Trade Policy (Ithaca, NY, 1993), pp. 81-131; Richard Bensel, The Political Economy of American Industrialization, 1866-1900 (Cambridge, 2000), pp. 457-460; Frank Taussig, The Tariff History of the United States (New York, 1964), pp. 170-276; Paul Bairoch, Economics and World History: Myths and Paradoxes (Chicago, 1993), p. 53; Percy Ashley, Modern Tariff History: Germany-United States-France (New York, 1970), pp. 181-204.

${ }^{10}$ James Huston, "The Political Response to Industrialism: The Republican Embrace of Protectionist Labor Doctrine," The Journal of American History (June, 1983).
} 
Skidmore. ${ }^{11}$ Ironically, voices that were counted as the least progressive with regard to economics before the Civil War were seen as prophetic of the need for a socialist economics to replace capitalism after the Civil War.

Perhaps the single element that draws the rather different antebellum reactionaries together with the postbellum socialist was their questioning of American exceptionalism. Fitzhugh, Holmes, Byllesby, and Skidmore were part of a larger corps of domestic thinkers familiar with European, particularly British patterns of industrial development. They rejected what they considered were the negative social, moral, and political residuals of industrialization. They found significance in the gloomy forecasts of Malthus and Ricardo and were convinced the consequences of industrial capitalism knew no national boundaries. My dissertation shows that the Northern and Southern reactionaries were not alien intruders to an otherwise optimistic liberal-capitalist discourse. Their brand of economic thought was widely circulated, helped shape the contours of the antebellum economic dialogue, and would prove to have an enduring appeal by resurfacing with greater tenacity later in the century.

Industrialization and the organization and efforts of labor in the post Civil War period, J. Laurence Laughlin wrote in the inaugural 1892 issue of the Journal of Political Economy, were largely responsible for broadening American curiosities in political economy. Industry was, however, not the primary feature in the postbellum discussion. Laughlin attributed what he called "the new-born interest in economics" to public outrage over currency and banking. ${ }^{12}$ During and after the Civil War financial institutions expanded rapidly, hastened by Republicans and

\footnotetext{
${ }^{11}$ David Montgomery, The Fall of the House of Labor: The Workplace, the State, and American Labor Activism, 1865-1925(Cambridge, 1927).

12 J. Laurence Laughlin, "The Study of Political Economy in the United States," The Journal of Political Economy (December, 1892), p. 4.
} 
Northeastern businessmen eager to mobilize the nation's capital, offer the public a cheap and stable medium of exchange, and transform the United States into a financial hegemon. ${ }^{13}$

Since this nation's founding the nature and responsibility of financial institutions have provoked a complex and energized agitation among economic thinkers. Antebellum attitudes toward finance reflected cultural and historical traditions deeply rooted in the American experience. Those who embraced much of the free-market agenda often stopped their celebration when it came to financial markets. In America, it was entirely possible to be a devoted champion of laissez-faire and simultaneously abhor finance.

After the Civil War the American economic discourse expressed a similar ambiguity toward financial institutions. Americans debated the advantages of a redeemable national currency, the intrinsic value of hard money, the dangers of bank monopolies, and the government's role in regulating financial markets. Financial issues were tied to moral concerns on the distribution of wealth, interest rates, the nature of private property, and the accumulation of profits. Industrialists, merchants, agrarians, and labor vacillated in their support for various financial schemes, often employing rhetorical strategies and a manner of thought that echoed antebellum economic thinkers. There was conflict over financial policy, and in words of the historian of Reconstruction finance Irwin Unger, "often it generated frustrations and aggression just short of the social flash point." ${ }^{, 14}$ As was the case in the antebellum period, it is hard to find consensus in the postbellum financial discourse.

My dissertation shows antebellum political economy was inclusive of an extensive and dynamic range of ideological and theoretical positions that made consensus. The American discourse was not dominated by British laissez-faire, and was routinely inviting of an economic

\footnotetext{
${ }^{13}$ Irwin Unger, The Greenback Era: A Social and Political History of American Finance, 1865-1879 (Princeton, 1964); Richard Franklin Bensel, Yankee Leviathan: The Origins of Central State Authority in America, 1859-1877 (Cambridge, 1990), chapters 4 and 5; Bensel, The Political Economy of American Industrialization, 1977-1900, chapter 6.

${ }^{14}$ Unger, The Greenback Era, p. 404.
} 
thought that complimented both the style and substance of the American experience. An awareness of these differences provide a clearer measure of American intellectual history and can improve our appreciation of how the economic dialogue helped set the narrative for the political discord that culminated with the Civil War. 


\section{BIBLIOGRAPHY}

Primary Sources

Appleton, Nathan. An Examination of the Banking System of Massachusetts, in Reference to the Renewal of the Bank Charters. Boston: Stimpson and Clapp, 1831.

. Remarks on Currency and Banking; Having Reference to the Present Derangement of the Circulating Medium in the United States. Boston: J.H. Eastburn, 1857.

Biddle, Nicholas. The Correspondences of Nicholas Biddle Dealing with National Affairs, $1807-$ 1844.Reginald Charles McGrane, ed. New York: Houghton Mifflin, 1919.

Blodget, Samuel. Economia: A Statistical Manual for the United States of America. Washington: n.p., 1806.

Bolingbroke, Henry St. John. Bolingbroke's Political Writings: The Conservative Enlightenment. Bernard Cottret, ed. New York: St. Martins, 1997.

Bowen, Francis. The Principles of Political Economy Applied to the Condition, and the Resources of the American People. New York: Garland, 1856, 1974.

Byllesby, Langton. Observations on the Sources and Effects of Unequal Wealth With Propositions Towards Remedying the Disparity of Profit in Pursuing the Arts of Life and Establishing Security in Individual Prospects and Resources. New York: L.J. Nichols, 1826, 1961.

Byrdsall, Fitzwilliam. History of the Loco-Foco or Equal Rights Party. New York: B. Franklin, $1842,1967$.

Calhoun, John C. The Papers of John C. Calhoun.28 vols. Robert L. Meriwether, W. Edwin Hemphill, and Clyde N. Wilson, eds. Columbia: University of South Carolina Press, 1959-2003. vols. X-XII, XIV.

. “The Tariff," Southern Quarterly Review, vol. 1, no. 2, 1842.

Cardozo, Jacob. Notes on Political Economy. New York: A.M. Kelley, 1826, 1972.

Carey, Henry. Essay on the Rate of Wages. New York: A.M. Kelley, 1835, 1965.

. Principles of Political Economy. 3 vols. New York: A.M. Kelley, 1837-1840, 1965.

. The Past, the Present, \& the Future. New York: A.M. Kelley, 1847, 1967.

. Principles of Social Science. 3 vols. New York: A.M. Kelley, 1858-1859, 1963.

. The Harmony of Interests, Agricultural, Manufacturing, and Commercial. New York:

A.M. Kelley, 1851, 1967. 
. Miscellaneous Works of Henry C. Carey.2 vols. New York: B. Franklin, 1883, 1967.

. The Unity of Law; as Exhibited in the Relations of Physical, Social, Mental and Moral Science. New York: A.M. Kelley, 1872, 1967.

Carey, Mathew, ed. Addresses of the Philadelphia Society for the Promotion of Domestic

Industry. New York: Garland, 1820, 1974.

. Essays on Political Economy, or the Most Certain Means of Promoting the Wealth,

Power, Resources, and Happiness of States Applied Particularly to the United States. New

York: A.M. Kelley, 1822, 1968.

. Autobiographical Sketches in a Series of Letters Addressed to a Friend. New York:

Arno, 1829, 1970.

Clinton, George. Essays on Banking. Richmond: Collins, 1829.

Colton, Calvin. The Junius Tracts. New York: Garland, 1844, 1974.

. The Rights of Labor. New York: Garland, 1846, 1974.

. Public Economy for the United States. New York: A.M. Kelley, 1848, 1969.

Cooper, Thomas. Two Tracts: On the Alteration of the Tariff; and on Weights and Measures.

Charleston: A.E. Miller, 1823.

. Lectures on the Elements of Political Economy. New York: A.M. Kelley, 1831, 1971.

. Philosophical Writings of Thomas Cooper. 3 vols. Udo Theil, ed. Bristol:

Thoemmes, 2001. vols. II-III.

Coxe, Tench. A Brief Examination of Lord Sheffield's Observations on the Commerce of the United States in Seven Numbers with two Supplementary notes on American

Manufactures. Philadelphia: Carey, Stewart, and Co.: 1792.

. A Statement of the Arts and Manufactures of the United States of America for the year 1810.Philadelphia: A. Cornman, 1814.

De Bow, J.D.B. The Industrial Resources, Statistics, \&c. of the United States and More

Particularly of the Southern and Western States.3 vols. New York: A.M. Kelley, 1854,

1966. vols. I-II.

. "Notes on Political Economy," De Bow's Southern and Western Review, vol. 36, no. 4, 1855.

. "Free Trade and Direct Taxation," De Bow's Southern and Western Review, vol. 27, no. $4,1857$.

. "The Non-Slaveholders of the South" (1860), in McKitrick, ed., 1963. 
Dew, Thomas. Lectures on the Restrictive System. New York: A.M. Kelley, 1829, 1969.

Review of the Debate in the Virginia Legislature, 1831 and 1832. Westport: Negro University Press, 1970.

Everett, Alexander. New Ideas on Population with Remarks on the Theories of Malthus and Godwin. With the addition of the correspondence between Everett and George Tucker on the Malthusian theory, published in The Democratic Review for 1845 \& 1847 . New York: A.M. Kelley, 1826, 1970.

. British Opinions of the Protecting System, Being a Reply to Strictures on that System, Which Have Appeared in Several Recent British Publications. Boston: Nathan Hale, 1830.

. Journal of the Proceedings of the Friends of Domestic Industry. New York: Garland, 1831, 1974.

Fisk, Theophilus. The Banking Bubble Burst; or the Mammoth Corruptions of the Paper Money System Relieved by Bleeding. Charleston: No. 63 Wentworth Street, 1837.

. Labor The Only True Source of Wealth; or the Rottenness of the Paper Money Banking System Exposed, Its Sandy Foundations Shaken, Its Crumbling Pillars Overthrown. New York: n.p., 1837, 1970.

Fitzhugh, George. Sociology for the South, or the Failure of Free Society. New York: B. Franklin, 1854, 1965.

. Cannibals All! or Slaves Without Masters. Cambridge: Harvard University Press, 1857, 1988.

. "The Impending Fate of the Country," De Bow's Southern and Western Review, vol. 2, no. $6,1866$.

Franklin, Benjamin. Essays on General Politics, Commerce and Political Economy. Jared Sparks, ed. New York: A.M. Kelley, 1971.

Gilbert, Amos. A Sketch of the Life of Thomas Skidmore. Chicago: C.H. Kerr, 1834, 1984.

Gouge, William. The Curse of Paper Money and Banking, or, A Short History of Paper Money and Banking in the United States of America. New York: Greenwood, 1833, 1968. . The Journal of Banking, July, 1841-July, 1842.London: Routledge, 1842, 1996.

Greeley, Horace, ed. The American Laborer. New York: Garland, 1843, 1973.

Hamilton, Alexander. The Works of Alexander Hamilton. 12 vols. Henry Cabot Lodge, ed. New York: G.P. Putman's, 1904. vols. II-IV. 
Harrington, James. The Political Works of James Harrington. J.G.A. Pocock, ed. Cambridge: Cambridge University Press, 1977.

Hildreth, Richard. Banks, Banking, and Paper Currencies: In Three Parts. New York: Greenwood, 1840, 1968.

Holmes, George Frederick. "Carlyle's Latter-Day Pamphlets," Southern Quarterly Review, vol. 18 , no. 2,1850 .

. “Greely on Reforms,” Southern Literary Messenger, vol. 17, no. 5, 1851.

. “The Nineteenth Century," Southern Literary Messenger, vol. 17, no. 8, 1851.

. "Review of Uncle Tom's Cabin" (1852), in McKirtrick, ed., 1963.

. "Failure of Free Societies," Southern Literary Messenger, vol. 21, no. 3, 1855.

. "Slavery and Freedom," Southern Quarterly Review, vol. 1, no. 1, 1856.

. "Speculation and Trade," Southern Quarterly Review, vol. 1, no. 1, 1856.

. “Capital and Labor,” De Bow's Southern and Western Review, vol. 22, no. 2, 1857.

Jackson, Andrew. The Statesmanship of Andrew Jackson as Told in His Writings and Speeches. Francis Newton Thorpe, ed. New York: Tandy-Thomas, 1909.

Leggett, William. A Collection of Political Writings of William Leggett.2 vols. Theodore Sedgwick, ed. New York: Arno, 1840, 1971. vol. II.

. Democratic Editorials: Essays in Jacksonian Political Economy. Lawrence H. White, ed. Indianapolis: Liberty Press, 1984.

List, Friedrich. The Natural System of Political Economy. London: F. Cass, 1837, 1983.

. National System of Political Economy. New York: Garland, 1841, 1974.

. Life of Friedrich List and Selections of His Writings. Margarate Hirst, ed. New York:

A.M. Kelley, 1909, 1965.

Malthus, Thomas. An Essay on the Principle of Population. Oxford: Oxford University Press, 1798, 1993. . An Essay on the Principle of Population. London: J. Johnson, 1803.

Marx, Karl. Capital. David McLellan, ed. Oxford: Oxford University Press, 1894, 1995.

Mather, Increase. The Great Blessing of Primitive Counsellors (1693), in Johnson, et. al., 2003. 
McCulloch, J.R. A Dictionary, Practical, Theoretical, and Historical, of Commerce and Commercial Navigation. 2 vols. Philadelphia: Carey and Hart, 1852. vol. II.

McDuffie, George. "Speech of McDuffie Against the Prohibitory System," Southern Quarterly Review, vol. 8, no. 15, 1831.

McVickar, John. Outlines of Political Economy: Being a Republication of an Article upon that subject contained in the Edinburgh Supplement to the Encyclopedia Britannica. New York: A.M. Kelley, 1825, 1966. . Introductory Lecture to a Course in Political Economy Delivered at Columbia University. London: J. Miller, 1830.

"Memorial to the Senate" (1831), in Everett, ed., 1974.

The Merchant's Magazine, December, 1842.

The New York Times, June 13, 1880.

Newman, Samuel. The Elements of Political Economy. Clifton: A.M. Kelley, 1835, 1973.

Niles' Weekly Register, December 28, 1816.

Opdyke, George. A Treatise on Political Economy. Clifton: A.M. Kelley, 1851, 1973.

Penn, William. A Brief Account of the Province of Pennsylvania (1681), in Johnson, et. al., 2003. . A Further Account of the Province of Pennsylvania (1685), in Johnson, et. al., 2003.

Phillips, Willard. Propositions Concerning Protection and Free Trade. New York: A.M. Kelley, $1850,1968$.

Pickering, John. The Working Man's Political Economy Founded upon the Principle of Immutable Justice, and the Inalienable Rights of Man; Designed for the Promotion of National Reform. New York: A.M. Kelley, 1847, 1971.

"Political Economy," The Southern Review, vol. 8, no. 16, 1832.

Raguet, Condy. A Treatise on Currency and Banking. New York: A.M. Kelley, 1840, 1967.

Raymond, Daniel. Thoughts on Political Economy. Baltimore: F. Lucas, 1820. . The Elements of Political Economy. 2 vols. New York: A.M. Kelley, 1823, 1964.

Ricardo, David. The Principles of Political Economy and Taxation. London: Everyman's, 1817, 1992. 
. The Works and Correspondences of David Ricardo.11 vols. Pierro Sraffa and M.H. Dobbs, eds. Indianapolis: Liberty Fund, 2005. vol. I.

Ruffin, Edmund. The Political Economy of Slavery, or, The Institution Considered in Regard to Its Influence on Public Wealth and the General Welfare (1853), in Finkelman, ed., 2003.

Say, Jean-Baptiste. Treatise on Political Economy; or the Production, Distribution and Consumption of Wealth. Boston: Wells and Lilly, 1803, 1824.

Simpson, Stephen. The Working Man's Manual: A New Theory of Political Economy on the Principle of Production the Source of Wealth. Philadelphia: T.L. Bonsal, 1831.

Skidmore, Thomas. The Rights of Man to Property! New York: B. Franklin, 1829, 1966. . Moral Physiology Exposed and Refuted. New York: Skidmore and Jacobs, 1831.

Smith, Adam. The Theory of Moral Sentiments. New York: A.M. Kelley, 1759, 1966. . An Inquiry into the Nature and Causes of the Wealth of Nations. 2 vols. New York: Modern Library, 1776, 1937.

Smith, E.P. A Manual of Political Economy. New York: Garland, 1853, 1974.

Smith, John. A Description of New England (1616), in Johnson, et. al., 2003.

Spooner, Lysander. Poverty, Its Illegal Causes and Legal Cure. New York: Da Capo, 1846, 1971. . The New System of Paper Currency. Boston: A. Williams, 1861.

Stewart, Andrew. Speeches on the Tariff and on Internal Improvements. New York: Garland, $1872,1974$.

Taylor, John. Arator: Being a Series of Agricultural Essays, Practical and Political. Baltimore: J. Robinson, 1817.

. Construction Construed and Constitutions Vindicated. Richmond: Shepherd and Pollard, 1820.

Tibbits, George. Essay on the Expediency of and Practicality of Improving of Creating Home Markets for the Sale of Agricultural Productions and Raw Materials by the Introduction or Growth of Artisans and Manufactures (1827), in M. Carey, ed., 1974.

Tocqueville, Alexis de. Democracy in America. New York: Bantam, 1835, 2000.

Trollope, Fanny. Domestic Manners of the Americans. London: Penguin, 1832, 1997.

Tucker, George. Essays on Various Subjects of Taste, Morals, and National Policy. Georgetown: Joseph Milligan, 1822. 
. The Laws of Wages, Profits and Rents Investigated. New York: A.M. Kelley, 1837, 1964.

. Progress of the United States in Population and Wealth in Fifty Years With an Appendix Containing an Abstract of the Census of 1850. New York: A.M. Kelley, 1855, 1964.

. The Life and Philosophy of George Tucker. 4 vols. James Fieser, ed. Bristol:

Thoemmes Continuum, 2004. vols. II, IV.

. "The Malthusian Theory Discussed in a Correspondence between Alexander Everett and Prof. George Tucker, May 14, 1844," The United States Magazine and Democratic Review (1845), in Everett, 1970.

Vethake, Henry. The Principles of Political Economy. New York: A.M. Kelley, 1844, 1971.

Ware, Nathaniel. Notes on Political Economy: As Applicable to the United States by a Southern Planter. New York: A.M. Kelley, 1844, 1967.

Wayland, Francis. The Elements of Moral Science. Cambridge: Harvard University Press, 1837, 1963.

. The Elements of Political Economy. New York: Leavitt, Lord, 1837.

Winthrop, John. A Model of Christian Charity (1630), in Johnson, et. al., 2003.

Secondary Sources

Abbot, Carl. Boosters and Businessmen: Popular Economic Thought and Urban Growth in the Antebellum West. Westport: Greenwood Press, 1981.

The American Historical Review, January, 1898.

Appleby, Joyce. Economic Thought and Ideology in $17^{\text {th }}$-century England. Princeton: Princeton University Press, 1978.

. Capitalism and a New Social Order: The Republican Vision of the 1790s. New York: New York University Press, 1984.

Ashley, Percy. Modern Tariff History: Germany-United States-France. New York: H. Fertig, 1970.

Ashworth, John. 'Agrarians' and 'Aristocrats': Party Political Ideology in the United States, 1837-1846. Cambridge: Cambridge University Press, 1987.

. Slavery, Capitalism, and Politics in the Antebellum Republic, Volume I: Commerce and Compromise, 1820-1860. Cambridge: Cambridge University Press, 1995. 
Bailyn, Bernard. The Ideological Origins of the American Revolution. Cambridge: Harvard University Press, 1967.

Bairoch, Paul. Economics and World History: Myths and Paradoxes. Chicago: University of Chicago Press, 1993.

Balen, Malcolm. A Very English Deceit: The Secret History of the South Sea Bubble and the First Great Financial Scandal. London: Fourth Estate, 2003.

Balleisen, Edward. Navigating Failure: Bankruptcy and Commercial Society in Antebellum America. Chapel Hill: University of North Carolina Press, 2001.

Banner, Stuart. Anglo-American Securities Regulation: Cultural and Political Roots, 1690-1860. Cambridge: Cambridge University Press, 1998.

Banning, Lance. The Jeffersonian Persuasion: Evolution of a Party Ideology. Ithaca: Cornell University Press, 1978.

Barber, William, ed. Economists and Higher Learning in the Nineteenth Century. New Brunswick: Transaction, 1993.

Bensel, Richard. Yankee Leviathan: The Origins of Central State Authority in America, 18591877. Cambridge: Cambridge University Press, 1990.

. The Political Economy of American Industrialization, 1877-1900. Cambridge:

Cambridge University Press, 2000.

Benson, Lee. The Concept of Jacksonian Democracy: New York as a Test Case. New York: Antheneum, 1967.

Blau, Joseph, ed. Social Theories of Jacksonian Democracry: Representative Writings of the Period, 1825-1850. New York: The Liberal Arts, 1954.

Bodenhorn, Howard. A History of Banking in Antebellum America: Financial Markets and Economic Development in the Era of Nation Building. Cambridge: Cambridge University Press, 2000.

Boorstin, Daniel. The Republic of Technology: Reflections on Our Future Community. New York: Harper, 1978.

Bronstein, Jamie. Land Reform and Working-Class Experience in Britain and the United States, 1800-1862. Stanford: Stanford University Press, 1999.

Brown, Roger. The Republic in Peril: 1812. New York: Columbia University Press, 1964.

Brown, Vivienne. Adam Smith's Discourse: Canonicity, Commerce, and Conscience. New York: Routledge, 1994. 
Burke, Martin. The Conundrum of Class: Public Discourse on the Social Order. Chicago: University of Chicago Press, 1995.

Cady, George Johnson. "The Early American Reaction to the Theory of Malthus," The Journal of Political Economy, vol. 39, no. 5, 1931.

Campbell, T.D. Adam Smith's Science of Morals. London: Allen and Unwin, 1971.

Carruthers, Bruce. City of Capital: Politics and Markets in the English Financial Revolution. Princeton: Princeton University Press, 1996.

Carsel, Wilfred. "The Slaveholders' Indictment of Northern Wage Slavery," The Journal of Southern History, vol. 6, no. 4, 1940.

Carswell, John. The South Sea Bubble. London: Cresset, 1960.

Cash, W.J.The Mind of the South. New York: Knopf, 1941.

Coats, A.W. Bob.On the History of Economic Thought. London: Routledge, 1992.

Cocks, Edmond."The Malthusian Theory in Pre-Civil War America: An Original Relation to the Universe," Population Studies, vol. 20, no. 3, 1967.

Cohen, Benjamin, and Charles Lipson, eds. Issues and Agents in International Political Economy: an International Organization Reader. Cambridge: MIT Press, 1999.

Cole, Arthur. The Whig Party in the South. Washington: American Historical Association, 1913.

Collini, Stefan, Richard Whatmore, and Brian Young, eds. Economy, Polity, and Society: British Intellectual History, 1750-1950. Cambridge: Cambridge University Press, 2000.

Conkin, Paul. Prophets of Prosperity: America's First Political Economists. Bloomington: Indiana University Press, 1980.

Cook, Elizabeth. Literary Influences in Colonial Newspapers, 1704-1750. Port Washington: Kennicak, 1966.

Cook, J.G. Anglophobia: An Analysis of Anti-British Prejudice in the United States. Boston: The Four Seas, 1919.

Cowles, Virginia. The Great Swindle: The Story of the South Sea Bubble. New York: Harper, 1960.

Cronon, William. Nature's Metropolis: Chicago and the Great West. New York: Norton, 1991.

Cropsey, Joseph. Polity and Economy: With Further Thoughts on the Principles of Adam Smith. South Bend: St. Augustine's, 2001.

Curti, Merle. The Growth of American Thought. New York: Harper, 1951. 
Dale, Richard. The First Crash: Lessons From the South Sea Bubble. Princeton: Princeton University Press, 2004.

Dalzell, Robert. Enterprising Elite: the Boston Associates and the World they Made. New York: Norton, 1987.

Dangerfield, George. The Awakening of American Nationalism, 1815-1828. New York: Harper, 1965.

Dawson, Andrew. "Reassessing Henry Carey (1793-1879): The Problem of Writing Political Economy in Nineteenth-Century America," Journal of American Studies, vol. 34, no. 3, 2000 .

Degler, Carl N. “The Locofocos: Urban 'Agrarians,' The Journal of Economic History, vol. 16, no. 3, 1956.

Dodd, William. "The Social Philosophy of the Old South," The American Journal of Sociology, vol. 23 , no. $6,1918$.

Dorfman, Joseph. The Economic Mind in American Civilization, 1606-1865. 2 vols. New York: Viking Press, 1946.

. The Economic Mind in American Civilization, 1865-1918. New York: A.M. Kelley, 1949.

. The Economic Mind in American Civilization, 1918-1933. 2 vols. New York: Viking Press, 1959.

. "The Jacksonian Wage-Earner Thesis," The American Historical Review, vol. 54, no. 2, 1949.

. "The Role of the German Historical School in American Economic Thought," The American Economic Review, vol. 45, no. 2, 1955.

. "On the Naturalization of Ricardian Economics in the United States," in McVickar, 1966.

. “L. Byllesby and His Plan for Economic Reconstruction,” in Byllesby, 1961.

. "William H. Gouge and the Formation of Orthodox American Monetary Policy," in Gouge, 1974.

. "Henry Vethake: JacksonianRicardian," in Dorfman and Tugwell, 1972.

and R.G. Tugwell. Early American Policy; Six Columbia Contributors. Plainview:

Books for Libraries: 1972.

, and R.G. Tugwell. "The Reverend John McVickar, Christian Teacher and Economists," in Dorfman and Tugwell, 1972. 
Douglas, Ann. The Feminization of American Culture. New York: Farrar, Straus, and Giroux, 1998.

Drescher, Seymour. The Mighty Experiment: Free Labor versus Slavery in British Emancipation. Oxford: Oxford University Press, 2002.

Du Bois, Armand. The English Business Company After the Bubble Act, 1720-1800. New York: Octagon, 1971.

Dunbar, Charles. "Economic Science in America, 1776-1876," The North American Review, vol. 122 , no. $250,1876$.

Eaton, Clement. The Freedom of Thought Struggle in the Old South. New York: Harper, 1964.

Edwards, Richard. "Economic Sophistication in Nineteenth Century Congressional Tariff Debates," The Journal of Economic History, vol. 30, no. 4, 1970.

Eiselen, Malcolm Rogers. The Rise of Pennsylvania Protectionism. New York: Garland, 1974.

Elkins, Stanley and Eric McKitrick. The Age of Federalism: The Early American Republic, 1788-1800. Oxford: Oxford University Press, 1993.

Ely, Richard. "A Decade of Economic Theory," Annals of the American Academy of Political and Social Science, vol. 15, no. 2.

Elzas, Barnett. The Jews of South Carolina: From the Earliest Times to the Present Day. Philadelphia: Lippincott, 1905.

Ferguson, E. James. The Power of the Purse: A History of American Public Finance, 1776-1790. Chapel Hill: University of North Carolina Press, 1961.

Fetter, Frank A. "The Early History of Political Economy in the United States," Proceedings of the American Philosophical Society, vol. 87, no. 1, 1943.

Fine, Sidney. Laissez-faire and the General Welfare State: A Study of Conflict in American Thought, 1865- 1901. Ann Arbor: University of Michigan Press, 1969.

Finkleman, Paul, ed. Defending Slavery: Proslavery Thought in the Old South. Boston: Bedford Books, 2003.

Fish, Carl Russel. The Rise of the Common Man, 1830-1850. New York: Macmillan, 1927.

Fleischacker, Samuel. "Adam Smith's Reception Among the American Founders, 1776- 1790," William and Mary Quarterly, $3^{\text {rd }}$ Series, vol. 59, no. 4, 2002.

Flora, Abram. "Economic Thought in South Carolina, 1820-1860." Diss. University of North Carolina, 1957. 
Foner, Eric. Free Soil, Free Labor, Free Men: The Ideology of the Republican Party Before the Civil War. Oxford: Oxford University Press, 1995.

Ford, Lacy.The Origins of Southern Radicalism: The South Carolina Upcountry. New York: Oxford University Press, 1988.

. "Republican Ideology in a Slave Society: The Political Economy of John C. Calhoun," The Journal of Southern History, vol. 54, no. 3, 1988.

Fox, Dixon Ryan.The Decline of Aristocracy in the Politics of New York, 1801-1840. New York: Harper, 1965.

Frey, Donald. “The Puritan Roots of Daniel Raymond's Economics," History of Political Economy, vol. 32, no. 3, 2000.

Freyer, Tony. Producers versus Capitalists: Constitutional Conflict in Antebellum America. Charlottesville: University Press of Virginia, 1994.

Gambles, Anna. Protection and Politics: Conservative Economic Discourse, 1815-1852. Suffolk: Royal Historical Society, 1999.

Garber, Peter. Famous First Bubbles: The Fundamentals of Early Manias. Cambridge: MIT Press, 2000.

Genovese, Eugene. The Political Economy of Slavery: Studies in the Economy and Society of the Slave South. New York: Pantheon, 1965.

. The World the Slaveholders Made: Two Essays in Interpretation. New York: Vintage, 1971.

. The Slaveholder's Dilemma: Freedom and Progress in Southern Conservative

Thought, 1820- 1860. Columbia: University of South Carolina Press, 1992.

Gibson, James. Americans versus Malthus: The Population Debate in the Early Republic, 17901840. New York: Garland, 1989.

Gide, Charles, and Charles Rist. History of Economic Doctrines: From the Time of the Physiocrats to the Present Day. New York: D.C. Heath, 1915.

Gillespie, Neal. The Collapse of Orthodoxy: The Intellectual Ordeal of George Frederick Holmes. Charlottesville: University Press of Virginia, 1972.

Gilpin, Robert. Global Political Economy: Understanding the International Economic Order. Princeton: Princeton University Press, 2001.

Glickstein, Jonathan. Concepts of Free Labor in Antebellum America. New Haven: Yale University Press, 1991. 
. American Exceptionalism, American Anxiety: Wages, Competition, and Degraded Labor in the Antebellum United States. Charlottesville: University Press of Virginia, 2002.

Goldstein, Judith. Ideas, Interests, and American Trade Policy. Ithaca: Cornell University Press, 1993.

Gordon, John Steele. Hamilton's Blessing: The Extraordinary Life and Times of Our National Debt. New York: Penguin, 1998. An Empire of Wealth: The Epic History of American Economic Power. New York: HarperCollins, 2004.

Grampp, William. The Manchester School of Economics. Stanford: Stanford University Press, 1960.

. "How Britain Turned to Free Trade," The Business History Review, vol. 61, no. 1, 1987.

Greenfeld, Liah. The Spirit of Capitalism: Nationalism and Economic Growth. Cambridge: Harvard University Press, 2001.

Gregory, Francis. W. Nathan Appleton, Merchant and Entrepreneur, 1779-1861. Charlottesville: University of Virginia Press, 1975.

Grimmer-Solem, Erik. The Rise of Historical Economics and Social Reform in Germany, 18641894. Oxford: Oxford University Press, 2002.

Griswold, Charles. Adam Smith and the Virtues of Enlightenment. Cambridge: Cambridge University Press, 1999.

Hacker, Louis M. The Triumph of American Capitalism: The Development of Forces in American History to the Beginning of the Twentieth Century. New York: Columbia University Press, 1947. . Alexander Hamilton in the American Tradition.New York: McGraw-Hill, 1957.

Hammond, Bray. Banks and Politics in America: From the Revolution to the Civil War. Princeton: Princeton University Press, 1967.

Harris, Seymour, ed. American Economic History. New York: McGraw-Hill, 1961.

Harrison, Lowell. "Thomas Roderick Dew: Philosopher of the Old South," The Virginia Magazine of History and Biography, vol. 57, no. 4, 1949.

Hartz, Louis. Economic Policy and Democratic Thought: Pennsylvania 1776-1860. Chicago: Quadrangle, 1968. 
. The Liberal Tradition in America: An Interpretation of American Political Thought Since the Revolution. New York: Harcourt, 1955.

Heilbroner, Robert. The Worldly Philosophers: The Lives, Times, and Ideas of the Great Economic Thinkers. New York: Touchstone, 1999.

Helderman, Leonard. "A Social Scientist of the Old South," The Journal of Southern History, vol. 28 , no. 3, 1936.

Henderson, W.O. List, Economist and Visionary, 1789-1846. Totowa: Cass, 1983.

Hilton, Boyd. The Age of Atonement: The Influence of Evangelicalism on Social and Economic Thought, 1785-1865. New York: Oxford University Press, 1988.

Hodgson, Dennis. "Malthus' Essay on Population and the American Debate over Slavery," Comparative Studies in Society and History, vol. 51, no. 4, 2009.

Hofstadter, Richard. Anti-Intellectualism in American Life. New York: Vintage, 1963.

. The American Political Tradition and the Men Who Made It. New York: Vintage, 1974.

Holt, Michael. The Rise and Fall of the American Whig Party: Jacksonian Politics and the Onset of the Civil War. Oxford: Oxford University Press, 1999.

Howe, Anthony. "Restoring Free Trade: the British experience, 1776-1873," in Winch and O’Brien, eds., 2002.

Howe, Daniel Walker. The Political Culture of the American Whigs. Chicago: University of Chicago Press, 1979.

. What Hath God Wrought: The Transformation of America, 1815-1848. New York: Oxford University Press, 2007.

Hudson, Michael. Economics and Technology in 19 ${ }^{\text {th }}$-Century American Thought. New York: Garland, 1975.

Hugins, Walter. Jacksonian Democracy and the Working Class: A Study of the New York Workingmen's Movement, 1829-1837. Stanford: Stanford University Press, 1960.

Huston, James. The Panic of 1857 and the Civil War. Baton Rouge: Louisiana State University Press, 1987.

. Securing the Fruits of Labor: American Concepts of Wealth Distribution. Baton Rouge: Louisiana State University Press, 1998.

. "The Political Response to Industrialism: The Republican Embrace of Protectionist Labor Doctrine," The Journal of American History, vol. 70, no. 1, 1983. 
Hutchison, T.W. On Revolutions and Progress in Economic Knowledge. Cambridge: Cambridge University Press, 1978.

Innes, Stephen. Creating the Commonwealth: The Economic Culture of Puritan New England. New York: Norton, 1995.

Jenkins, William. Pro-Slavery Thought in the Old South. Gloucester: P. Smith, 1960.

Johnson, E.A.J. American Economic Thought in the Seventeenth Century. New York: Russell and Russell, 1961.

Johnson, Marianne, Seven G. Medema, and Warren J. Samuels, eds. Foundation of the American Economy: The American Colonies from Inception to Independence. From Theocracy to Secular, Materialist Commercial Society. 5 vols. London: Pickering and Chatto, 2003. vol. I.

Kaplan, A.D.H. Henry Carey: A Study in American Economic Thought. Baltimore: Johns Hopkins Press, 1931.

Kasson, John. Civilizing the Machine: Technology and Republican Values in America, 17761900. New York: Penguin, 1977.

Kaufman, Allen. Capitalism, Slavery, and Republican Values: Antebellum Political Economists, 1819-1848. Austin: University of Texas Press, 1982.

Kelley, Robert. The Transatlantic Persuasion: The Liberal-Democratic Mind in the Age of Gladstone. New York: Knopf, 1969.

Kiker, B.F., and Robert J. Carlson, eds. South Carolina Economists: Essays on the Evolution of Antebellum Economic Thought. Columbia: The Bureau of Business and Economic Research, 1969.

Kindleberger, Charles P. Manias, Panics, and Crashes: A History of Financial Crises. New York: John Wiley, 2000.

Kloppenberg, James T. "The Virtues of Liberalism: Christianity, Republicanism, and Ethics in Early American Political Discourse," The Journal of American History, vol. 74, no. 1, 1987.

Kraus, Michael. The North Atlantic Civilization.Princeton: Van Norstrand, 1957.

Kulikoff, Allan. The Agrarian Origins of American Capitalism. Charlottesville: University of Virginia Press, 1992.

Langstaff, J.B. The Enterprising Life: John McVickar, 1787-1868. New York: St. Martin's, 1961. 
Larson, John Lauritz. The Market Revolution in America: Liberty, Ambition, and the Eclipse of the Common Good. Cambridge: Cambridge University Press, 2010.

. Internal Improvement: National Public Works and the Promise of Popular

Government in the Early United States. Chapel Hill: University of North Carolina Press, 2001.

Laughlin, Laurence. "The Study of Political Economy in the United States," The Journal of Political Economy, vol. 1, no. 1, 1892.

Laurie, Bruce. Artisans into Workers: Labor in Nineteenth-Century America. New York: Hill and Wang, 1989.

Lause, Mark. Young America: Land, Labor and the Republican Community. Urbana: University of Illinois Press, 2005.

Leiman, Melvin. Jacob Cardozo: Economic Thought in the Antebellum South. Columbia: University of South Carolina Press, 1966.

Letwin, William. The Origins of Scientific Economics: English Economic Thought, 1660-1776. London: Methuen, 1963.

Lingred, J. Ralph. The Social Philosophy of Adam Smith. The Hague: Nijhoff, 1973

Lipset, Seymour. American Exceptionalism: A Double-edged Sword. New York: Norton, 1996.

Lowenthal, Esther. The Ricardian Socialists. New York: Columbia University Press, 1924.

Madsen, Deborah. American Exceptionalism.Jackson: University of Mississippi Press, 1998.

Mangold, G.B. The Labor Argument in the American Tariff Discussion. New York: Garland, 1974.

Mann, Bruce. Republic of Debtors: Bankruptcy in the Age of American Independence. Cambridge: Harvard University Press, 2002.

Mansfield, Edward, and Marc Busch."The Political Economy of Nontariff Barriers: A CrossNational Analysis," International Organization, vol. 49, no. 4, 1995.

Marx, Leo. The Machine in the Garden: Technology and the Pastoral Ideal in America. Oxford: Oxford University Press, 2000.

May, Henry F. The Enlightenment in America. Oxford: Oxford University Press, 1976.

McCord, Norman. The Anti-Corn Law League, 1838-46. London: Allen \&Unwin, 1953.

McCormick, Richard P. The Second American Party System: Party Formation in the Jacksonian Era. New York: Norton, 1966. 
McCoy, Drew. The Elusive Republic: Political Economy in Jeffersonian America. Chapel Hill: University of North Carolina Press, 1980.

McCusker, John, and Russell Menard. The Economy of British America, 1607-1789. Chapel Hill: University of North Carolina Press, 1991.

McKitrick, Eric, ed. Slavery Defended: The Views of the Old South. Englewood Cliffs: PrenticeHall, 1963.

McFaul, John. The Politics of Jacksonian Finance. Ithaca: Cornell University Press, 1972.

McGee, Robert. A Trade Policy for Free Societies: The Case Against Protectionism. Westport: Quorum, 1994.

McGrane, Reginald Charles. The Panic of 1837: Some Financial Problems of the Jacksonian Era. Chicago: University of Chicago Press, 1965.

McKeown, Timothy. "Hegemonic Stability Theory and $19^{\text {th }}$ Century Tariff Levels in Europe," International Organization, vol. 37, no. 1, 1983.

McNamara, Peter. Political Economy and Statesmanship: Smith, Hamilton, and the Foundation of the Commercial Republic. DeKalb: Northern Illinois University Press, 1998.

Messer-Kruse, Timothy. The Yankee International: Marxism and the American Reform Tradition, 1848-1876. Chapel Hill: University of North Carolina Press, 1998.

Milner, Helen, and David Yoffie, "Between Free Trade and Protectionism: Strategic Trade Policy and a Theory of Corporate Trade Demand," International Organization, vol. 31, no. 4, 1989.

Montgomery, David. The Fall of the House of Labor: The Workplace, the State, and American Labor Activism, 1865-1925. Cambridge: Cambridge University Press, 1987.

Morrison, Rodney J. "Henry C. Carey and American Economic Development," Transactions of the American Philosophical Society, vol. 76, part 3, 1986.

Morrow, Glen. The Ethical and Economic Theories of Adam Smith. New York: A.M. Kelley, 1969.

Mudge, Eugene Tenbroeck. The Social Philosophy of John Taylor of Caroline: A Study in Jeffersonian Democracy. New York: AMS, 1968.

Neal, Larry. The Rise of Financial Capitalism: International Markets in the Age of Reason. Cambridge: Cambridge University Press, 1990.

Neil, C.P. Daniel Raymond: An Early Chapter in the History of Economic Theory in the United States. New York: A.M. Kelley, 1974. 
Normano, J.F. The Spirit of American Economics: A Study of the History of Economic Ideas in the United States Prior to the Great Depression. New York: John Day, 1943.

Notz, William. "Frederick List in America," The American Economic Review, vol. 16, no. 2, 1926.

Nye, David. American Technological Sublime. Cambridge: MIT Press, 1994.

O'Brien, Michael. Conjectures of Order: Intellectual Life and the American South, 1810-1860. 2 vols. Chapel Hill: University of North Carolina Press, 2004. vol. II.

O'Connor, Michael. Origins of Academic Economics in the United States. New York: Garland, 1974.

Onuf, Nicholas, and Peter Onuf. Nations, Markets, and War: Modern History and the American Civil War. Charlottesville: University of Virginia Press, 2006.

Palgrave, Robert Harry Inglis, ed. Dictionary of Political Economy. 3 vols. London: Macmillan and Co., 1894, vol. I.

Patterson, Margaret, and David Reiffen, "The Effects of the Bubble Act on the Market for Joint Stock Shares," The Journal of Economic History, vol. 50, no. 1, 1990.

Pessen, Edward. Most Uncommon Jacksonians: The Radical Leaders of the Early Labor Movement. Albany: State University of New York Press, 1967.

. Riches, Class, and Power Before the Civil War. Lexington: D.C. Heath, 1973.

. Jacksonian America: Society, Personality, and Politics. Homewood: Dorsey Press, 1978.

Peterson, Merrill. The Great Triumvirate: Webster, Clay, Calhoun. Oxford: Oxford University Press, 1987.

. Olive Branch and Sword: The Compromise of 1833. Baton Rouge: Louisiana State University Press, 1982.

Pickering, Paul, and Alex Tyrrell. The People's Bread: A History of the Anti-Corn Law League. London: Leicester University Press, 2000.

Pincus, Jonathan. Pressure Groups and Politics in Antebellum Tariffs. New York: Columbia University Press, 1977.

Pocock, J.G.A. The Machiavellian Moment: Florentine Political Thought and the Atlantic Republican Tradition. Princeton: Princeton University Press, 1975.

. "Virtue and Commerce in the Eighteenth Century," The Journal of Interdisciplinary History, vol. 3, no. 1, 1972. 
Polanyi, Karl. The Great Transformation: The Political and Economic Origins of Our Times. Boston: Beacon, 2001.

Rabbeno, Ugo. American Commercial Policy. London: Macmillan, 1895.

Rader, Benjamin. "William M. Gouge Jacksonian Economic Theorist," Pennsylvania History, vol. 30 , no. 4, 1963.

Remini, Robert. Andrew Jackson and the Course of American Democracy, 1832-1845. New York: Harper, 1984.

Robbins, Caroline. The Eighteenth-Century Commonwealth Man: Studies in the Transmission, Development and Circumstances of English Liberal Thought from the Restoration of Charles II until the War with the Thirteen Colonies. Cambridge: Harvard University Press, 1961.

Roll, Eric. A History of Economic Thought. New York: Prentice-Hall, 1942.

Ross, Dorothy. The Origins of American Social Science. Cambridge: Cambridge University Press, 1991.

Rossiter, Clinton. Conservatism in America. Cambridge: Harvard University Press, 1982.

Rowe, Kenneth. Matthew Carey: A Study in American Economic Development. Baltimore: Johns Hopkins Press, 1933.

Rutherford, Malcolm, ed. The Economic Mind in America: Essays in the History of American Economics. London: Routledge, 1998.

Sandage, Scott. Born Losers: A History of Failure in America. Cambridge: University of Harvard Press, 2005.

Schabas, Margaret. The Natural Origins of Economics. Chicago: University of Chicago Press, 2005.

Schlesinger, Arthur. The Age of Jackson.Boston: Little, Brown, 1946.

. "Ideas and the Economic Process," in Harris, ed., 1961.

. "The Problem of Richard Hildreth,” The New England Quarterly, vol. 13, no.2, 1940.

Schumpeter, Joseph. History of Economic Analysis. Oxford: Oxford University Press, 1954.

Seligman, Edwin. Essays in Economics. New York: Macmillan, 1964.

Sellers, Charles. The Market Revolution: Jacksonian America, 1815-1848. New York: Oxford University Press, 1991. 
Semmel, Bernard. The Rise of Free Trade Imperialism: Classical Political Economy, the Empire of Free Trade and Imperialism. Cambridge: Cambridge University Press, 1970.

Shade, William. Banks or No Banks: The Money Issue in Western Politics, 1832-1865. Detroit: Wayne State University Press, 1972.

Sharp, James Roger.The Jacksonians versus the Banks: Politics in the States after the Panic of 1837. New York: Columbia University Press, 1970. . American Politics in the Early Republic: The New Nation in Crisis. Hartford: Yale University Press, 1993.

Sheldon, Garrett Ward and C. William Hill, The Liberal Republicanism of John Taylor of Caroline. Madison, N.J.: Fairleigh Dickinson University Press, 2008.

Sherwood, Sidney. "Tendencies in American Economic Thought," Johns Hopkins Studies, series 15 , no. $12,1897$.

Shore, Laurence. Southern Capitalists: The Ideological Leadership of an Elite, 1832-1885. Chapel Hill: University of North Carolina Press, 1986.

Shalhope, Robert. John Taylor of Caroline: Pastoral Republican. Columbia: University of South Carolina Press, 1980.

Skinner, Andrew. A System of Social Science: Papers Relating to Adam Smith. Oxford: Oxford University Press, 1996.

Skipper, Ottis Clark. "J.D.B. De Bow, the Man," The Journal of Southern History, vol. 10, no. 4, 1944.

Sklansky, Jeffrey. The Soul's Economy: Market Society and Selfhood in American Thought, 1820-1920. Chapel Hill: University of North Carolina Press, 2002.

Smith, George Winston. Henry C. Carey and American Sectional Conflict. Albuquerque: University of New Mexico Press, 1951.

Smith, Henry. Virgin Land: The American West as Symbol and Myth. New York: Vintage, 1957.

Smith, Roy. Adam Smith and the Origins of American Enterprise: How America's Industrial Success was Forged by the Timely Ideas of a Brilliant Scots Economist. New York: St. Martin's Press, 2002.

Snavely, Tipton. George Tucker as Political Economist. Charlottesville: University of Virginia Press, 1964.

Snyder, Louis. The Roots of German Nationalism. Bloomington: Indiana University Press, 1978.

Sombart, Werner. Why There is no Socialism in the United States? White Plains: M.E. Sharp, 1976. 
Spengler, Joseph. "Population Doctrines in the United States.I.Anti-Malthusianism," The Journal of Political Economy, vol. 41, no. 4, 1933.

. "Population Doctrines in the United States. II. Malthusians," The Journal of Political Economy, vol. 41, no. 5, 1933.

. "Population Theory in the Ante-Bellum South," The Journal of Southern History, vol. 2, no. 3, 1936.

Spiegel, Henry William, ed. The Rise of American Economic Thought. Philadelphia: Chilton, 1960.

. The Growth of Economic Thought. Englewood Cliffs: Prentice Hall, 1971.

Stanwood, Edward. American Tariff Controversies of the Nineteenth Century. 2 vols. New York: Garland, 1974.

Stigler, George. "Ricardo and the 93\% Labor Theory of Value," The American Economic Review, vol. 48, no. 3, 1958.

Stone, Gabriel. Hezekiah Niles as an Economist. Baltimore: Johns Hopkins University Press, 1933.

Stourzh, Gerald. Alexander Hamilton and the Idea of Republican Government. Stanford: Stanford University Press, 1970.

Sylla, Richard. "Monetary Innovation in America," The Journal of Economic History, vol. 42, no. $1,1982$.

Taussig, Frank. The Tariff History of the United States. New York: Capricorn, 1964.

Tawney, R.H. Religion and the Rise of Capitalism. London: Transaction, 2000.

Taylor, Robert. Cavalier and Yankee: The Old South and American National Character. New York: G. Braziller, 1961.

Teichgraeber, Richard. 'Free Trade' and Moral Philosophy: Rethinking the Sources of Adam Smith's Wealth of Nations. Oxford: Oxford University Press, 1988.

Teilhac, Ernest. Pioneers of American Economic Thought in the Nineteenth Century. New York: McMillian, 1936.

Thistlethwaite, Frank. The Anglo-American Connection in the Early Nineteenth Century. New York: Russell \& Russell, 1971.

Thompson, Noel. The People's Science: The Political Economy of Exploitation and Crisis 18161834. Cambridge, Cambridge University Press, 1984. 
Turner, John Roscoe. The Ricardian Rent Theory in Early American Economics. New York: New York University Press, 1921.

Unger, Irwin. The Greenback Era: A Social and Political History of American Finance, 18651879. Princeton: Princeton University Press, 1964.

Viner, Jacob. The Long View and the Short. Glencoe: Free Press, 1958.

. Essays on the Intellectual History of Economics. Douglas Irwin, ed. Princeton: Princeton University Press, 1971.

Vivenza, Gloria. Adam Smith and the Classics: The Classical Heritage in Adam Smith's Thought. Oxford: Oxford University Press, 2001.

Walther, Eric H. The Fire-Eaters. Baton Rouge: Louisiana State University Press, 1992.

Watson, Harry L. Jacksonian Politics and Community Conflict: The Emergence of the Second Party System in Cumberland County, North Carolina. Baton Rouge: Louisiana State University Press, 1981.

. Liberty and Power: The Politics of Jacksonian America. New York: Hill and Wang, 2006.

Watts, Steven. The Republic Reborn: War and the Making of Liberal America, 1790-1820. Baltimore: Johns Hopkins University Press, 1987.

Wilentz, Sean. Chants Democratic: New York City and the Rise of the American Working Class, 1788-1850. New York: Oxford University Press, 1984. . The Rise of American Democracy, Jefferson to Lincoln. New York: Norton, 2005.

Wilhite, Virgle. Founders of American Economic Thought and Policy. New York: Bookman, 1958.

Williams, William Appleman. "The Age of Mercantilism," The William and Mary Quarterly, $3^{\text {rd }}$ Series, vol. 15, no. 4, 1958.

Wilson, Major. "The 'Country' versus the 'Court': A Republican Consensus and Party Debate in the Bank War," Journal of the Early Republic, vol. 15, no. 4, 1995.

Winch, Donald. Adam Smith's Politics: An Essay in Historiographic Revision. Cambridge: Cambridge University Press, 1978. . Riches and Poverty: An Intellectual History of Political Economy in Britain, 17501834. Cambridge: Cambridge University Press, 1996. and O'Brien, Patrick K., eds. The Political Economy of British Historical Experience, 1688-1914. Oxford: Oxford University Press, 2002. 
Wood, Gordon. The Creation of the American Republic, 1776-1787. New York: Norton, 1969.

Wood, John Cunningham, ed. David Ricardo: Critical Assessments. London: Croom Helm, 1985.

Woodward, C. Van, "George Fitzhugh, Sui Generis," in Fitzhugh, 1857.

Wright, Robert. The Wealth of Nations Rediscovered: Integration and Expansion in American Financial Markets, 1780-1850. New York: Cambridge University Press, 2002.

Yarbrough, Beth, and Robert Yarbrough, "Cooperation in the Liberalization of International Trade: After Hegemony, What?" (1987), in Cohen and Lipson, eds., 1999. 


\section{VITA}

\section{CHRISTOPHER WILLIAM CALVO}

October 27, 1978

2000

2002

2004-2005

2005-2006

2005-present

2002-2012
Born, Miami, Florida

B.A., History

Florida International University

Miami, Florida

M.A., History

Florida International University

Miami, Florida

Copy Editor/Editorial Assistant

Enterprise and Society

Oxford's International Journal of Business History

Adjunct Professor

Department of History

Florida International University

Miami, Florida

Faculty

Social Sciences Department

Gulliver Preparatory

Miami, Florida

Doctoral Student

Department of History

Florida International University

Miami, Florida 